PATRICIA ARGENTA TONIOLO

AVALIAÇÃO DA TRANSFECÇÃO DE CÉLULAS DENDRÍTICAS COM RNA TUMORAL COMO ESTRATÉGIA PARA INDUÇÃO DE IMUNIDADE ESPECÍFICA EM PACIENTES COM LEUCEMIA LINFÓIDE CRÔNICA

Dissertação apresentada ao Programa de Pós-Graduação em Imunologia do Instituto de Ciências Biomédicas da Universidade de São Paulo para obtenção do Título de Mestre em Ciências.

São Paulo

2010 
PATRICIA ARGENTA TONIOLO

\section{AVALIAÇÃO DA TRANSFECÇÃO DE CÉLULAS DENDRÍTICAS COM RNA TUMORAL COMO ESTRATÉGIA PARA INDUÇÃO DE IMUNIDADE ESPECÍFICA EM PACIENTES COM LEUCEMIA LINFÓIDE CRÔNICA}

Dissertação apresentada ao Programa de Pós-Graduação em Imunologia do Instituto de Ciências Biomédicas da Universidade de São Paulo para obtenção do Título de Mestre em Ciências.

Área de concentração: Imunologia

Orientador: Prof. Dr. José Alexandre M. Barbuto 
DADOS DE CATALOGAÇÃO NA PUBLICAÇÃO (CIP)

Serviço de Biblioteca e Informação Biomédica do

Instituto de Ciências Biomédicas da Universidade de São Paulo

(c) reprodução total

Toniolo, Patricia Argenta.

Avaliação da transfecção de células dendríticas com RNA tumoral como estratégia para indução de imunidade específica em pacientes com leucemia linfóide crônica / Patricia Argenta Toniolo. -- São Paulo, 2010.

Orientador: Jose Alexandre Marzagão Barbuto.

Dissertação (Mestrado) - Universidade de São Paulo. Instituto de Ciências Biomédicas. Departamento de Imunologia. Área de concentração: Imunologia. Linha de pesquisa: Imunologia de tumores

Versão do título para o inglês: Evaluation of dendritic cell transfection with tumor RNA as a strategy to induce specific immunity in chronic lymphoid leukemia patients.

Descritores: 1. Células dendríticas 2. RNA tumoral 3. Survivina 4. Transfecção I. Barbuto, Jose Alexandre Marzagão II. Universidade de São Paulo. Instituto de Ciências Biomédicas. Programa de Pós Graduação em Imunologia III. Título. 
Candidato(a):

Título da Dissertação:

Orientador(a):
Patricia Argenta Toniolo.

Avaliação da transfecção de células dendríticas com RNA tumoral como estratégia para indução de imunidade específica em pacientes com leucemia linfóide crônica.

A Comissão Julgadora dos trabalhos de Defesa da Dissertação de Mestrado, em sessão pública realizada a ..................................,
( ) Aprovado(a)
( ) Reprovado(a)

Examinador(a): Assinatura:

Nome:

Instituição:

Examinador(a): Assinatura:

Nome:

Instituição:

Presidente: Assinatura:

Nome:

Instituição: 
UNIVERSIDADE DE SÃO PAULO

INSTITUTO DE CIÊNCIAS BIOMÉDICAS

Cidade Universitária "Armando de Salles Oliveira"

Av. Prof. Lineu Prestes, 2415 - cep. 05500-000 Saulo, SP - Bras

e-mail: cep@ icb.usp.br

São Paulo, 20 de junho de 2008.

\section{PARECER 843/CEP}

Prezada Senhora

Atendendo sua solicitação, a Comissão de Ética em Pesquisas com Seres Humanos do ICB, em sua $84^{a}$ reunião realizada em 21.05 .08 , analisou o projeto de sua responsabilidade intitulado: "Avaliação da transfecção de células dendriticas com RNA tumoral como estratégia para indução de imunidade especifica em pacientes com leucemia linfóide crônica".

Informo a V.Sa. que, após análise e discussão, o referido projeto foi aprovado por esta Comissão.

Lembramos que cabe ao pesquisador elaborar e apresentar a este Comitê, relatórios anuais (parciais ou final), de acordo com a resolução 196/06 do Conselho Nacional da Saúde, item IX.2 letra c.

O primeiro relatório deverá ser encaminhado à Secretaria deste CEP em 21 de maio de 2009.

Atenciosamente,

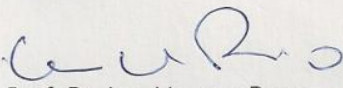

Prof. Dr. LUIZ VICENTE RIZZO

Coordenador da Comissão de Ética em

Pesquisas com Seres Humanos - ICB/USP

IIma. Sra.

PATRÍCIA ARGENTA TONIOLO

Departamento de Imunologia

Instituto de Ciências Biomédicas -USP

Comissão de Ética em Pesquisa com Seres Humanos do Instituto de Ciências Biomédicas I USP

Aprovada pela Comissão Nacional de Ética em Pesquisa - CONEP, em 10 de fevereiro de 1998. 
Aos meus pais, irmãos e amigos pela dedicação, apoio e incentivo durante estes anos de mestrado. 


\section{AGRADECIMENTOS}

Aos meus pais pelo carinho e incentivo constante à minha educação, além de todo suporte financeiro, e aos meus irmãos pelo apoio.

Ao meu orientador Prof. Dr. José Alexandre M. Barbuto pela oportunidade de trabalhar em seu laboratório e contribuir para minha formação.

À Prof ${ }^{\mathrm{a}}$ Dra. Mary Cleide Sogayar por ter me recebido em seu laboratório, cedido reagentes e permitido que lá fosse realizada a parte de biologia molecular deste trabalho. Em especial, agradeço ao seu aluno Marcos que me acompanhou e auxilou nos experimentos e com quem aprendi muita coisa de genética.

A todos os professores do departamento que cederam parte de seu laboratório e equipamentos, e também por contribuírem com idéias e soluções.

Aos funcionários do departamento e aos amigos da portaria Milton, Octacílio, Roberto, Odair e Ailton.

Aos amigos Jotelma, Amanda, Thiago, Eni, Celso e Amarildo (in memoriam) pela ajuda nas questões burocráticas.

À Célia pela atenção desde que cheguei ao laboratório e pelas boas risadas durante esses anos.

Aos meus amigos Bruna, Gio, Grá, Isabella, Lilian e Rodrigo pelo companheirismo nesta jornada dupla de estudo e trabalho (momentos de estresse, alegrias, conselhos, happy hour, etc...).

Aos amigos de laboratório de Imunologia de Tumores Ana Carolina, Cristiano, Daniel, Giovana Alonso, Karen, Murilo, Patrícia Bergami, Renatson, Roberta, Roberto pela boa companhia e por compartilhar bons momentos dentro e fora do laboratório. 
Ao grande amigo Otávio que esteve sempre presente nos momentos em que mais precisei de ajuda.

Aos colegas do departamento pela amizade, discussões imunológicas e momentos de descontração.

A FAPESP pelo apoio financeiro.

E a todas as pessoas que ajudaram na realização deste trabalho de forma direta ou indireta.

Obrigada a todos! 
"O primeiro passo para conseguirmos o que queremos na vida é decidirmos o que queremos."

(Ben Stein) 


\section{RESUMO}

TONIOLO, P. A. Avaliação da transfecção de células dendríticas com RNA tumoral como estratégia para indução de imunidade específica em pacientes com leucemia linfóide crônica. 2010. 110 f. Dissertação (Mestrado em Imunologia) - Instituto de Ciências Biomédicas, Universidade de São Paulo, São Paulo, 2010

O desenvolvimento da imunoterapia do câncer baseada em células dendríticas (DCs) é alvo de vários estudos. Para tumores sólidos, a abordagem baseada no uso de DCs alogenêicas fundidas com células tumorais tem se mostrado relativamente eficaz. Por outro lado, esta estratégia necessita uma massa tumoral considerável de cada paciente para a geração das células híbridas. Para contornar este problema 0 uso de DCs transfectadas com mRNA tumoral, o qual pode ser amplificado in vitro a partir de uma pequena amostra inicial do tumor, tem sido investigado. Para isto, uma transfecção eficiente e tradução correta do mRNA tumoral nas DCs são etapas críticas. Sabendo-se que as DCs de pacientes com câncer possuem atividade aloestimuladora defeituosa, DCs derivadas de doadores saudáveis poderiam ser uma alternativa para induzir uma resposta imune mais eficiente. Assim, este trabalho pretendeu aprimorar a metodologia de transfecção de DCs alogenêicas, derivadas de monócitos de doadores saudáveis, com mRNA de antígenos tumorais (survivina e RPSA) super-expressos na leucemia linfóide crônica (LLC) e avaliar sua capacidade em estimular a resposta linfocitária. Ao mesmo tempo, foram estabelecidas as metodologias para amplificação e síntese do RNA destes antígenos tumorais específicos, assim como do RNA mensageiro total, contidos nas células tumorais de pacientes com LLC. Os resultados mostraram ser possível a amplificação do mRNA total extraído das células leucêmicas com manutenção da expressão dos antígenos tumorais. Ainda, várias condições de transfecção com mRNA da survivina, transcrito in vitro, foram testadas, encontrando-se na lipofecção, a melhor maneira de transfectar as DCs. A lipofecção mostrou-se com baixa toxicidade quando comparada à técnica de eletroporação. Observou-se uma eficiência em torno de $40 \%$ de células transfectadas num intervalo de tempo entre 12 e 48 horas. Estas células foram usadas como estimuladoras em ensaios de proliferação usando-se linfócitos $T$ alogenêicos como células respondedoras. As células transfectadas com mRNA da survivina foram capazes de estimular resposta linfoproliferativa com maior produção de IFN-gama, avaliado por ELISA. Além disso, a transfecção não alterou o padrão de expressão dos marcadores de superfície característicos das DCs. Estes dados mostram que a transfecção das DCs com mRNA pode afetar a resposta imune induzida por estas APCs. Nossos resultados suportam o uso de DCs transfectadas com mRNA para produção de vacinas antitumorais e mostram a survivina como um potente antígeno indutor da resposta linfocitária.

Palavras-chave: Células Dendríticas. Survivina. RNA tumoral. Transfecção 


\begin{abstract}
TONIOLO, P. A. Evaluation of dendritic cell transfection with tumor RNA as a strategy to induce specific immunity in chronic lymphoid leukemia patients. 2010. 110 p. Master thesis (Immunology) - Instituto de Ciências Biomédicas, Universidade de São Paulo, São Paulo, 2010.

The development of dendritic cell (DC)-based cancer immunotherapy has been the target of many studies. For solid tumors, a promising approach based in allogeneic DCs fused to tumor cells has been relatively effective. On the other hand, this approach needs large tumor samples to generate enough DC-tumor cell hybrids. To overcome this problem, tumor mRNA-transfected DCs can be used, since mRNA can be amplified in vitro and allow unlimited vaccine production. For this, efficient transfection and optimal translation of tumor mRNA in DCs are critical. Moreover, DC derived from cancer patients has defective alostimulatory activity. In this case, DC derived from healthy donors may be an alternative to induce immune response more efficiently. Here, we established the methodology of allogeneic DC transfection with mRNA for tumor antigens (survivin and RPSA) overexpressed in chronic lymphocytic leukemia (CLL), and evaluated their ability for T cell stimulation. At the same time, we established mRNA amplification and mRNA in vitro transcription methodology for specific tumor antigens and total messenger RNA, present in CLL tumor cells. Our results showed it to be possible to amplify total mRNA derived from leukemic cells maintaining tumor antigen expression. Moreover, several transfection conditions using survivin mRNA obtained from in vitro transcript reactions were evaluated, defining lipofection as the better way to transfect DC. We obtained nearly $40 \%$ of transfected DCs between 12 and 48 hours. Transfected DCs were used as stimulator cells in proliferation assays using allogeneic $T$ cells as responder cells. Survivin mRNA transfected DCs were able to stimulate T cell proliferation with increased IFNgama production, measured by ELISA. Furthermore, the transfection did not change the pattern of surface molecules expression characteristic of DC. These data show that mRNA DC transfection can affect immune responses induced by these APCs. These findings support the use of tumor mRNA transfected DCs for anti-cancer vaccine production and show survivin as a potent antigen to induce $\mathrm{T}$ cell responses.
\end{abstract}

Key words: Dendritic cell. Survivin. Tumor RNA. Transfection 


\section{LISTA DE ILUSTRAÇÕES}

Figura 1 - Gráficos ilustrando o modo de análise de monócitos, DCs imaturas e DCs maduras para caracterização fenotípica por citometria de fluxo.

Figura 2 - Gráficos ilustrando o modo de análise das DCs transfectadas com DNA e RNA por citometria de fluxo.

Figura 3 - Esquema simplificado das etapas fundamentais para realização da transcrição in vitro.

Figura 4 - Gráficos ilustrando as células controles da marcação com anexina-V e PI.

Figura 5 - Curvas de dissociação dos primers para os genes $\beta$-actina, survivina e RPSA. .58

Figura 6 - Fotomicrografias do aspecto morfológico da cultura de diferenciação em DCs

Figura 7 - Freqüência de células no gate de tamanho (FSC) por granulosidade (SSC) característicos de DCs, nos meios de cultura AIM-V e R10...62

Figura 8 - Freqüência de células expressando os marcadores HLA-DR, CD14, CD80, CD86, CD40, CD83, CD11c, CD123 e CD1a, em monócitos iDCs e mDCs cultivadas no meio AIM-V.

Figura 9 - Freqüência de células expressando os marcadores HLA-DR, CD14, CD80, CD86, CD40, CD83, CD11c, CD123 e CD1a, em monócitos iDCs e mDCs cultivadas no meio R10.

Figura 10 - Verificação da funcionalidade do vetor plasmideal pLV-EGFP através da lipofecção em linhagem celular 293T.

Figura 11 - Eletroporação das DC imaturas com pLV-EGFP em glicose 5\%.....69

Figura 12 - Morfologia das células após eletroporação ..................................70

Figura 13 - Gráficos representativos da viabilidade celular após eletroporação.

Figura 14 - Fotografias de microscopia de fluorescência indicativas da lipofecção das DCs.

Figura 15 - Histogramas representativos da porcentagem de lipofecção das DCs imaturas, em meio AIM-V, com diferentes concentrações de pLV/EGFP e lipossomos. 
Figura 16 - Comparação da transfecção do pLV-EGFP entre as populações de DCs com alta e baixa expressão de CD86

Figura 17 - Comparação das populações de células transfectadas com pLVEGFP nos meios de cultura AIM-V e RPMI .75

Figura 18 - Perfil de restrição do vetor pGEM-T Easy-EGFP.. 77

Figura 19 - Perfil de restrição dos vetores pOTB7-survivina e pCMV-SPORT6RPSA.

Figura 20 - Linearização dos vetores pOTB7-survivina e pCMV-SPORT6RPSA. .80

Figura 21 - Transcrição in vitro dos cDNAs do EGFP, survivina e RPSA.

Figura 22 - Histogramas representativos da lipofecção de DCs imaturas, em meio R10, com diferentes concentrações de mRNA da survivina e agente de transfecção.

Figura 23 - Comparação das freqüências e dos valores de MFI-relativo entre DCs transfectadas com diferentes concentrações de mRNA da survivina e agente de transfecção

Figura 24 - Comparação das freqüências de células no gate de tamanho (FSC) por granulosidade (SSC) entre DCs sem tratamento, DCs tratadas com agente de transfecção e DCs transfectadas com os complexos mRNA /lipossomos.

Figura 25 - Cinética da porcentagem de células survivina ${ }^{+}$e da intensidade mediana de fluorescência da survivina após a transfecção das DCs com mRNA. 86

Figura 26 - Gráficos representativos da viabilidade celular após lipofecção com mRNA da survivina.

Figura 27 - Comparação fenotípica entre DCs sem tratamento e DCs tratadas com agente de transfecção ou com mRNA da survivina

Figura 28 - Gráficos mostrando a freqüência de células expressando os marcadores HLA-DR, CD14, CD80, CD86, CD40 e CD83 em DCs sem tratamento, DCs tratadas com agente de transfecção e DCs transfectadas com mRNA da survivina .90

Figura 29 - Concentração de IL-12p70 e IL-10 no sobrenadante da cultura de DCs sem tratamento, DCs tratadas com agente de transfecção e DCs transfectadas com mRNA da survivina 
Figura 30 - Capacidade das DCs transfectadas com mRNA da survivina estimularem linfócitos $\mathrm{T}$ alogenêicos............................................92

Figura 31 - Concentração de IFN- $\gamma$ e IL-10 no sobrenadante da co-cultura de linfócitos alogenêicos com DCs controles e DCs transfectadas com

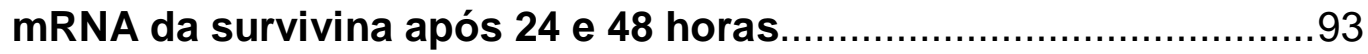

Figura 32 - Separação de células tumorais, obtidas a partir de células do sangue periférico de paciente com LLC, por esferas magnéticas...94

Figura 33 - Eletroforese em gel de agarose dos extratos de RNA tumoral total

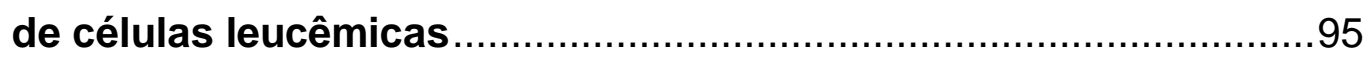

Figura 34 - Esquemas da estratégia de amplificação do mRNA tumoral total ..96

Figura 35 - Esquema da estratégia de transcrição in vitro .97

Figura 36 - Expressão dos antígenos tumorais survivina e RPSA antes e após a amplificação do mRNA total obtido de células leucêmicas .98 


\section{LISTA DE TABELAS}

Tabela 1 - Características clínicas dos pacientes estudados 36

Tabela 2 - Dados referentes aos anticorpos murinos usados para citometria de fluxo.

Tabela 3 - Tamanho dos fragmentos de DNA esperados, após a digestão do vetor pGEM-T Easy-EGFP, caso o gene EGFP esteja clonado no sentido do promotor SP6, com as enzimas de restrição EcoRI, Ncol, Sall, Pstl e HindIII.

Tabela 4 - Tamanho dos fragmentos de DNA esperados, após a digestão dos vetores pOTB7-survivina e pCMV-SPORT6-RPSA, com as enzimas de restrição Ncol, Smal e EcoRI/Xhol, e com as enzimas HindlII, Ncol e NotI/Sall, respectivamente, caso o EGFP esteja clonado no sentido do promotor SP6.

Tabela 5 - Seqüências dos primers utilizados nas reações de PCR em tempo real.

Tabela 6 - Porcentagem de células expressando EGFP, observadas após 24 e/ou 48 horas da eletroporação com diferentes combinações de meio (glicose $5 \%$ ou RPMI), em volumes finais na cubeta de $0,2,0,5$ ou $1 \mathrm{~mL}$, e com capacitâncias de $25 \mu \mathrm{F}$ ou $150 \mu \mathrm{F}$. 68 


\section{LISTA DE ABREVIATURAS E SIGLAS}

A adenina

ANOVA Análise de Variância

APCs Células Apresentadoras de Antígenos

ATP Adenosina trifosfato

BSA Albumina Bovina do Soro

C Citosina

CCR7 Receptor de quimiocina 7

CD Cluster of diferentiation

cDNA DNA Complementar

CFSE Carboxyfluorescein succinimidyl ester

CDS Região codificadora

Ct Threshold Cicle

CTLs Células T citotóxicas

CTP Citosina trifosfato

DCs Células Dendríticas

DEPC Água Tratada com Dietil Dicarbonato

DMSO Dimetilsulfóxido

DNA Ácido Desoxirribonucléico

dNTPs Desoxirribonucleotídeos Trifosfatados

DTT Ditiotreitol

EDTA Etilenodiaminotetracético

EGFP Abreviatura do inglês Enhanced Green Fluorescent Protein

FSC Foward Scatered

Fc Fragmento constante das imunoglobulinas

G Guanina

G2/M Fase do ciclo celular Gap2/Mitose

GM-CSF Fator de Crescimento de Colônia de Granulócito e Macrófago

GTP Guanosina trifosfato

HLA Antígeno Leucocitário Humano

HLA-DR Antígeno Leucocitário Humano-DR

iDCs Células Dendríticas Imaturas

IFN-Y Interferon- $\mathrm{y}$ 
IE

Índice de estimulação

IL Interleucina

Ig Imunoglobulina

kDa Kilo Dalton

Lin Lineage

LPS Lipopolissacarídeo

LLC Leucemia linfóide crônica

LRS Câmara de leucorredução

mDCs Células Dendríticas Maduras

MFI Intensidade Mediana de Fluorescência

MHC Complexo Principal de Histocompatibilidade

MLR Reação mista de linfócitos

mRNAs RNAs Mensageiro

NF-kB Fator nuclear kB

NTPs Ribonucleotídeos Trifosfatados

NK Células Natural Killer

OFA-iLRP Proteína Receptora de Laminina imatura-Antígeno Oncofetal pb Pares de bases

PBMCs Células Mononucleares do Sangue Periférico

PBS Solução Salina Tamponada com Fosfato

PCR Reação em Cadeia da Polimerase

PGE-2 Prostaglandina E2

PI lodeto de Propídeo

PoliA Ácido poliadenílico

qPCR Reação em Cadeia Polimerase quantitativa

RNA Ácido Ribonucléico

RPSA Proteína ribosomal SA

RPMI Meio Roswell Park Memorial Institute

R10 RPMI suplementado com $10 \%$ de soro fetal bovino

RT Transcrição Reversa

SFB Soro Fetal Bovino

SK-BR-3 Linhagem de adenocarcinoma mamário humano

SP6 Promotor do fago SP6 


$\begin{array}{ll}\text { SSC } & \text { Side Scatered } \\ \text { T } & \text { Timina } \\ \text { T7 } & \text { Promotor do fago T7 } \\ \text { TAAs } & \text { Antígenos associados ao tumor } \\ \text { TCR } & \text { Receptor de Células T } \\ \text { TLR } & \text { Receptor do tipo toll } \\ \text { TGF- } \beta & \text { Fator de Transformação do Crescimento } \beta \\ \text { TNF } \alpha & \text { Fator de Necrose Tumoral } \alpha \\ \text { Tregs } & \text { Linfócitos T reguladores } \\ \text { UTR } & \text { Região não traduzida } \\ \text { UTP } & \text { Uridina trifosfato } \\ \text { VEGF } & \text { Fator de Crescimento Endotelial Vascular } \\ \text { 293T } & \text { Linhagem celular de rim humano embrionário } \\ \text { 48S } & \text { Subunidade ribossomal 48 }\end{array}$




\section{SUMÁRIO}

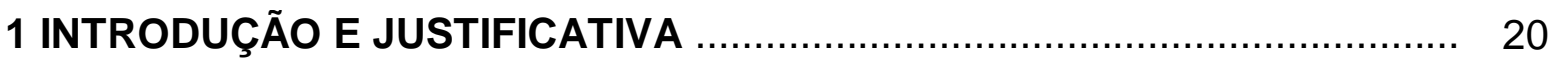

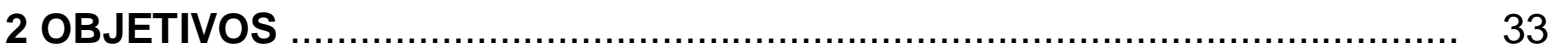

2.1 Objetivo Geral ......................................................................... 34

2.2 Objetivos Específicos ….............................................................. 34

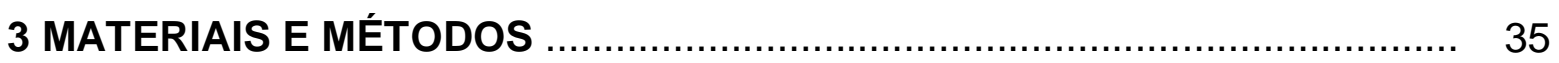

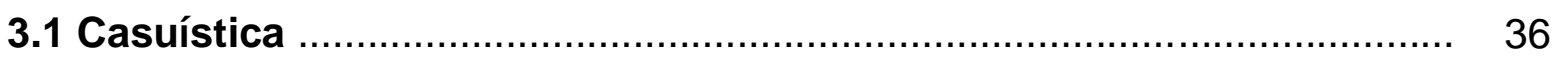

3.2 Isolamento de monócitos para diferenciação em DCs in vitro.................. 36

3.3 Avaliação do fenótipo de membrana das DCs por citometria de fluxo.. 37

3.4 Marcação de moléculas intracelulares................................................ 39

3.5 Método de análise dos monócitos, DCs imaturas e maduras .............. 39

3.6 Transfecção da linhagem celular 293-T com vetor plasmideal pLVEGFP e mRNA da EGFP................................................................ 40

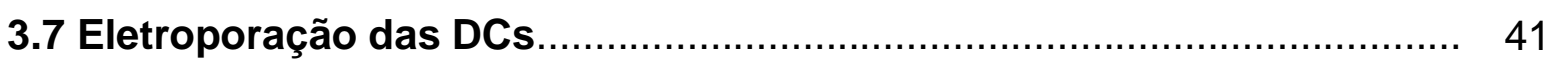

3.8 Lipofecção das DCs.................................................................. 42

3.9 Método de análise das DCs transfectadas ....................................... 44

3.10 Preparação dos moldes de cDNA da EGFP, RPSA e Survivina para síntese de mRNA por transcrição in vitro................................................ 46

3.10.1 Clonagem da EGFP no plasmídeo pGEM-T Easy ............................. 46

3.10.2 Extração do DNA plasmideal e digestão dos clones de cDNA do

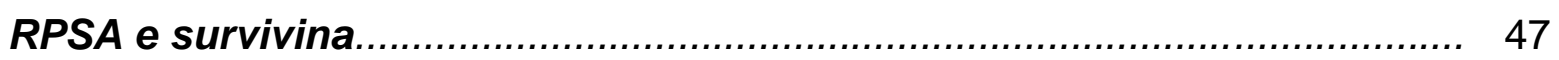

3.11 Transcrição in vitro..................................................................... 49

3.12 Avaliação da viabilidade celular ................................................... 50

3.13 Avaliação da atividade aloestimuladora das DCs transfectadas com mRNA.

3.14 Detecção da produção de citocinas por ensaio imunoenzimático (ELISA)

3.15 Obtenção das células leucêmicas...................................................... 53

3.16 Extração de RNA total das células leucêmicas................................... 54

3.17 Transcrição reversa (RT-PCR) e amplificação do mRNA tumotal total (PCR)

3.18 Transcrição in vitro do cDNA total amplificado ................................ 56

3.19 PCR quantitativa em tempo real (qPCR) ........................................... 56 
3.20 Análises estatísticas

4 RESULTADOS

4.1 Caracterização morfológica e fenotípica de monócitos, DCs imaturas e maduras

4.2 Transfecção das DCs com vetor plasmideal pLV-EGFP 66

4.2.1 Eletroporação das DCs 67

4.2.2 Lipofecção das DCs 71

4.3 Síntese do mRNA de antígenos específicos 76

4.3.1 Clonagem do EGFP no plasmídeo pGEM-T Easy 76

4.3.2 Obtenção e linearização das regiões codificadoras dos antígenos tumorais RPSA e survivina 78

4.3.3 Transcrição in vitro do EGFP, RPSA e survivina 80

4.4 Transfecção com mRNA dos antígenos tumorais 82

4.4.1 Avaliação da viabilidade celular após a transfecção com mRNA 87

4.4.2 Avaliação fenotípico-funcional das DCs transfectadas com mRNA .. 88

4.5 Obtenção das células leucêmicas 93

4.6 Extração, amplificação e transcrição in vitro do RNA tumoral total . 95 5 DISCUSSÃO 99

6 CONCLUSÕES 109 REFERÊNCIAS 


\section{INTRODUÇÃO E JUSTIFICATIVA}


O sistema imune funciona como um sistema de reconhecimento que conta com a participação coordenada de seus componentes inatos e adaptativos a fim de gerar uma resposta imunológica efetiva. Neste sentido, as células dendríticas (DCs), células apresentadoras de antígenos profissionais (APCs; do inglês, antigen presenting cells), destacam-se por exercerem papel essencial na iniciação e modulação da resposta imune, possuindo a capacidade única de promover a conexão entre imunidade inata e adaptativa. Nelas encontra-se a habilidade de captura de antígenos, através dos receptores inatos, integrada à sua capacidade de estimular linfócitos $T$ naive, induzindo sua diferenciação quer em células efetoras, quer em células reguladoras (BANCHEREAU et al., 2000; STEINMAN e BANCHEREAU, 2007).

$\mathrm{Na}$ maioria dos tecidos, as DCs encontram-se em um estado imaturo, monitorando o microambiente onde se encontram através da captura de antígenos. Embora estas células apresentem grande capacidade endocítica, não estão aptas a estimular linfócitos $T$ naive, uma vez que não possuem os níveis necessários de sinais acessórios para ativação primária dos linfócitos (BANCHEREAU e STEINMAN, 1998; MELLMAN e STEINMAN, 2001; MOHAMADZADEH e LUFTIG, 2004). Num estado imaturo, as $D C s$ induzem linfócitos $T$ à anergia ou à diferenciação em células supressoras (STEINMAN, 2003). No entanto, frente a estímulos pró-inflamatórios, as DCs sofrem processo de diferenciação e maturação, caracterizado pela redução da capacidade endocítica e aumento da expressão de moléculas de classe II codificadas pelo complexo principal de histocompatibilidade (MHC-II) e de moléculas co-estimuladoras (CD80, CD86 e CD40), além da secreção de grande quantidade de citocinas pró-inflamatórias (CAUX et al., 1994; BANCHEREAU et al., 2000). Durante o processo de maturação, as DCs passam a expressar o receptor para a quimiocina CCR7, que direciona sua migração aos órgãos linfóides secundários (SALLUSTO et al., 1999; GUERMONPREZ et al., 2002), onde são capazes de recrutar outras DCs e linfócitos T (ADEMA et al., 1997). Após sua maturação fenotípica e funcional, as DCs tornam-se competentes na ativação de linfócitos T (BANCHEREAU e STEINMAN, 1998; BANCHEREAU et al., 2000).

Diante do papel que as DCs representam na condução da resposta imune, a possibilidade de sua geração in vitro (CAUX et al., 1992; SALLUSTO e LANZAVECCHIA, 1994; ROMANI et al., 1996) abriu novas abordagens para terapia 
do câncer, que vem sendo exploradas intensamente nos últimos anos (BARBUTO et al., 2004; BANCHEREAU e PALUCKA, 2005; WANG et al., 2009). Em modelos murinos, o estudo da aplicação de DCs para preparação de vacinas preventivas e terapêuticas proporcionou resultados animadores (MAYORDOMO et al., 1995), e desde então, estudos clínicos têm sido realizados utilizando DCs carregadas com antígenos tumorais. Tendo em vista a utilização destas células para produção de vacinas terapêuticas, diferentes metodologias vêm sendo estudadas, considerandose a escolha do alvo da resposta a ser induzida, assim como o estado de maturação e ativação das DCs.

A natureza dos antígenos tumorais e a forma de carregamento das DCs têm grande impacto na capacidade destes antígenos estimularem linfócitos T CD4 ${ }^{+}$ou $\mathrm{CD}^{+}$. As DCs podem ser pulsadas com antígenos exógenos, tais como peptídeos, proteínas, lisados tumorais, corpos apoptóticos e antígenos complexados com anticorpos, ou podem ser manipuladas de forma a sintetizarem endógenamente os antígenos tumorais, através da transfecção com mRNA (RNA mensageiro) ou cDNA (DNA complementar) que codificam os mesmos (GILBOA, 2007; PALMA et al., 2008).

Uma metodologia que vêm rendendo bons resultados em modelos murinos é o carregamento das DCs com imunocomplexos. Esta técnica consiste em complexar proteínas associadas ao tumor a anticorpos lgG específicos. Além de promover apresentação dos antígenos via moléculas codificadas pelo $\mathrm{MHC}$ de classe I e pelo MHC de classe II, os imunocomplexos ativam as DCs por meio da ligação com seus receptores Fc (SCHUURHUIS et al., 2006). Outro artifício para direcionar antígenos tumorais às DCs seria por meio do uso de peptídeos acoplados a ligantes e agonistas de TLR ("Toll Like Receptor") (KHAN et al., 2007) (BALEEIRO et al., 2010). Ainda, nanovesículas originadas de compartimentos endossomais das DCs, os exossomos, também surgem como uma promissora abordagem para imunoterapia do câncer (ROMAGNOLI et al., 2010). Os exossomos derivados de DCs parecem ser eficientes em estimular células NK e linfócitos T, contribuindo desta forma, para ativação do sistema inato (VIAUD et al., 2009) e adaptativo (CHAPUT et al., 2004). Em estudos pré-clínicos foi observado que a vacinação com peptídeos apresenta maior eficácia antitumoral quando estes são carreados por exossomos (CHAPUT et al., 2004; VIAUD et al., 2010). 
Apesar destas abordagens com peptídeos antigênicos sintéticos, derivados de antígenos associados ao tumor (TAAs; do inglês, tumor associated antigens), mostrarem-se eficazes na indução de resposta clínica e imunológica em pacientes com câncer (BROSSART et al., 2000; GIANNOPOULOS et al., 2006; BARSOUM et al., 2009), estas respostas são limitadas aos antígenos escolhidos e a certos alelos do HLA (Antígeno Leucocitário Humano; do inglês, human leucocyte antigen). Para que a estratégia de vacinação terapêutica seja, de fato, eficaz, é necessária a identificação de antígenos tumorais que induzam uma resposta imune efetiva em indivíduos de diferentes constituições no HLA e que seja capaz de prevenir o escape tumoral (pela perda de expressão dos antígenos imunizantes). Tal seria, idealmente, conseguido pelo desenvolvimento de uma estratégia de imunização polivalente.

Neste aspecto, o uso de RNA para a "sensibilização" das DCs possui algumas vantagens. Uma delas é a facilidade de obtenção deste ácido nucléico, a partir das células neoplásicas. Além do mais, há possibilidade do emprego de mRNAs codificando antígenos tumorais específicos ou do RNA total isolado do tumor. A utilização do RNA tumoral total possui importante papel na indução de uma resposta imunológica ampla, gerada contra múltiplos TAAs, evitando assim a restrição da resposta a determinados alelos do HLA, que pode ocorrer com o uso de antígenos únicos e minimizando o risco de escape do tumor pela perda do TAA (BOCZKOWSKI et al., 2000; GILBOA e VIEWEG, 2004; MULLER et al., 2004; WANG et al., 2009). Mais recentemente, tem-se aplicado os RNAs em uma nova estratégia que parece aumentar a capacidade das DCs em estimular a resposta de linfócitos $\mathrm{T} \mathrm{CD8}^{+}$específicos aos antígenos tumorais (BONEHILL et al., 2008; BONTKES et al., 2008; BONEHILL et al., 2009). Esta estratégia consiste em carregar as DCs com RNAs que codificam antígenos tumorais simultaneamente a RNAs codificando proteínas imunoestimuladoras, tais como IL-12 (BONTKES et al., 2008), CD40L, CD70 e TLR-4 (BONEHILL et al., 2008; BONEHILL et al., 2009).

As várias metodologias que empregam o uso de DCs para produção de vacinas terapêuticas, ora pulsando-as com antígenos exógenos, ora transfectandoas com ácidos nucléicos que codificam antígenos tumorais, têm demonstrado bom desempenho na estimulação de resposta imune antígeno específicas. Entretanto, apesar dos progressos obtidos na imunoterapia do câncer, os resultados clínicos permanecem, ainda, insatisfatórios (ROSENBERG; YANG; RESTIFO, 2004). Estas respostas clínicas desanimadoras podem ser um reflexo da utilização de DCs 
derivadas de monócitos do próprio paciente com câncer, para o desenvolvimento das estratégias descritas, até então, neste trabalho. Vários estudos, inclusive do nosso grupo, mostraram que, em pacientes com câncer, as DCs derivadas de monócitos sanguíneos, in vitro, possuem fenótipo típico de células imaturas e redução na capacidade de induzir linfoproliferação quando comparadas às DCs obtidas de doadores saudáveis (AZEVEDO-SANTOS, 2010). Ainda, DCs imaturas derivadas de células de pacientes com carcinoma de mama parecem apresentar maior capacidade de induzir linfócitos T reguladores (RAMOS, 2010). Portanto, as dificuldades em se conseguir melhoras nos resultados clínicos com imunoterapia podem ser decorrentes destas falhas na maturação e ativação das DCs dos pacientes com câncer, o que pode refletir na capacidade destas células serem direcionadas aos linfonodos e lá induzirem uma resposta imune efetora contra as células tumorais. Além disso, estas falhas nas DCs podem causar seu carregamento ineficiente com antígenos tumorais (GILBOA, 2007; BOCZKOWSKI e NAIR, 2010).

Assim, esta limitação da atividade das DCs pode ser decorrente de mecanismos de escape tumoral, os quais têm se mostrado como fator limitante para o sucesso da imunoterapia do câncer. Considerando-se que as DCs desempenham importante papel no reconhecimento e apresentação de antígenos tumorais e que as células tumorais contêm antígenos reconhecidos ou reconhecíveis pelo sistema imunológico do paciente (WOLFEL et al., 1995; MANDRUZZATO et al., 1997; PIESCHE et al., 2007), não surpreendentemente, as DCs tornam-se alvos do escape tumoral. De fato, os tumores liberam fatores solúveis, tais como VEGF, IL-6, IL-10, TGF- $\beta$, capazes de afetar a diferenciação e maturação das DCs (GABRILOVICH, 2004; GOTTFRIED; KREUTZ; MACKENSEN, 2008). Tanto é, que em pacientes neoplásicos, há um número reduzido das DCs maduras funcionalmente competentes (DELLA BELLA et al., 2003; ORSINI et al., 2003; BALEEIRO et al., 2008), caracterizadas pela baixa expressão das moléculas importantes para apresentação de antígenos, como moléculas codificadas pelo MHC, CD80, CD86. Além disso, citocinas pró-inflamatórias, importantes para desencadear a resposta imunológica, são produzidas em níveis reduzidos pelas DCs (ALMAND et al., 2000; BELLONE et al., 2006). Por outro lado, a presença de IFNgama tanto nos linfonodos quanto no microambiente tumoral pode contribuir para mais um mecanismo de escape envolvendo as DCs. Esta citocina é capaz de promover a troca das subunidades catalíticas do proteassoma padrão para as 
subunidades catalíticas do imunoproteassoma, nas células tumorais e nas DCs. O processamento de antígenos tumorais para geração de epítopos antigênicos, muitas vezes só ocorre se a degradação destes antígenos for realizada pelo proteassoma padrão. Sendo assim, a presença do imunoproteassoma nas DCs de pacientes com neoplasias, resulta na ausência de apresentação de certos epítopos tumorais imunogênicos (MOREL et al., 2000). Ainda, as DCs, no tumor, parecem acumular lipídeos, mais especificamente triglicerídeos, e isto acaba por reduzir a sua capacidade de processamento e apresentação de antígenos. De maneira geral, estas células são incapazes de ativar linfócitos $T$ específicos e podem induzir tolerância imune (HERBER et al., 2010).

Dentre os vários mecanismos de escape tumoral que afetam as DCs, um dos motivos que também pode interferir no sucesso pleno da imunoterapia pode estar relacionado com defeitos funcionais encontrados desde os precursores das DCs de pacientes com câncer, mesmo que elas sejam diferenciadas in vitro na ausência de fatores derivados do tumor (HASEBE et al., 2000; DELLA BELLA et al., 2003; ORSINI et al., 2003; NEVES et al., 2005; TREFZER et al., 2005; WANG et al., 2006). Como alternativa para contornar este e os demais inconvenientes encontrados quando se trata do uso de DCs autólogas, surgiram estratégias que se fundamentam no uso de DCs alogênicas derivadas de doadores saudáveis fundidas com células tumorais autólogas (TREFZER et al., 2000; DALL'OGLIO; SROUGI; BARBUTO, 2003; BARBUTO et al., 2004). Nosso grupo demonstrou que utilizando o protocolo de vacinação com células híbridas houve uma estabilização da doença em cerca de $70 \%$ dos pacientes com melanoma metastático ou com carcinoma celular renal, por um período mediano de cerca de 6 meses, e sem efeitos colaterais significativos (BARBUTO et al., 2004). Esta abordagem do uso de DCs alogenêicas, além de fornecer um estímulo adjuvante para a vacina, permite que antígenos tumorais, conhecidos ou não, sejam processados endogenamente e apresentados, mediante a co-estimulação adequada, teoricamente, no contexto de suas moléculas do MHC e no contexto das moléculas do MHC do tumor.

Por outro lado, esta estratégia torna necessária a obteção de uma massa tumoral considerável de cada paciente para a geração das células híbridas. Isto pode ser um obstáculo pllara pacientes que apresentem tumores pequenos, onde a disponibilidade de células tumorais dificulta a preparação de vacinas individualizadas a partir destas células. Nestes casos, a transfecção de DC com RNA total extraído 
de células tumorais poderia fornecer a solução. A metodologia do RNA tem a vantagem de permitir sua amplificação in vitro, o que tornaria possível a produção ilimitada da vacina a partir de uma pequena amostra inicial do tumor. Boczkowski et al. (2000) mostraram, em modelo murino, ser possível amplificar o mRNA a partir de células cancerosas e induzir boa resposta de linfócitos $T$ citotóxicos ( $C T L)$ utilizando-se como células estimuladoras DCs transfectadas com este mRNA amplificado. Além do mais, estudos pré-clínicos usando esta estratégia em tumores sólidos humanos (HEISER et al., 2001; JARNJAK-JANKOVIC et al., 2005b), assim como malignidades hematológicas (JARNJAK-JANKOVIC et al., 2005a) também foram promissores. De maneira geral, experimentos pré-clínicos e clínicos que se utilizam da administração de DCs autólogas transfectadas com RNA total, assim como a aplicação direta do RNA por diferentes vias de administração que atinjam as DCs, in situ, mostraram-se factíveis e não tóxicos (BOCZKOWSKI et al., 2000; GILBOA e VIEWEG, 2004; JARNJAK-JANKOVIC et al., 2005b; MU et al., 2005; WEIDE et al., 2008; WEIDE et al., 2009).

Mais uma vez, quando se trata da produção de vacinas baseadas no uso de DCs deve-se levar em conta que a dose do antígeno representa um dos fatores críticos para a geração de uma resposta imune antígeno-especifica eficaz. Sendo assim, considerando-se que o RNA possui tempo de meia vida curto, é importante verificar o intervalo de tempo que este ácido nucléico estará íntegro para ser traduzido nas DCs e desta forma, otimizar-se a melhor concentração do mRNA a ser transfectada.

Algumas características presentes neste ácido nucléico o tornam mais estável e traduzido de forma mais eficiente pelas células. Um mRNA maduro típico de células eucarióticas contém uma região codificadora formada pela junção dos éxons durante o processamento do pré-mRNA, e em suas extremidades 3' e 5' possuem regiões não codificantes, chamadas de 3'UTR e 5'UTR, respectivamente. Além disso, um resíduo de guanina (G) modificada, conhecido como cap (7metilguanosina ou $\mathrm{m}^{7} \mathrm{G}$ ) é adicionado enzimaticamente à extremidade 5' do RNA, através de uma ligação trifosfato 5'-5'. Este cap possui importante papel em várias etapas do metabolismo do RNA, como o reconhecimento específico do mRNA maduro pelo fator de iniciação da tradução elF4E, para formação do complexo de pré-iniciação da tradução 48S, e estabilidade do RNA no processo de síntese protéica. A maioria dos mRNAs eucarióticos apresentam na sua extremidade 3' uma 
série de nucleotídeos de ácido adenílico (ácido poliadenílico ou poli(A)), o que também contribui para aumentar a estabilidade deste ácido nucléico (GRIFFTHS et al., 1985). Dessa forma, é importante que, o mRNA sintetizado in vitro, usado para transfectar as DCs, tivesse as estruturas do mRNA típico, a fim de se obter melhores resultados na eficiência de sua tradução. Por isso, na síntese no RNA, in vitro, realiza-se o capeamento durante a transcrição de um molde de cDNA, com uma RNA polimerase, na presença dos quatro nucleotídeos trifosfato (ATP, UTP,CTP e GTP) juntamente com uma estrutura homologa do cap endógeno (BOCZKOWSKI e NAIR, 2010; KUHN et al., 2010).

Outro ponto relevante, quando se trata do uso de RNA na imunoterapia, é a forma como ele será incorporado pelas DCs. Os métodos de transfecção de RNA são variados, incluindo lipofecção, eletroporação e transfecção passiva. Esta última técnica foi utilizada originalmente como controle, e surpreendeu ao mostrar resultados semelhantes, e até superiores aos de lipofecção, na indução de linfócitos T citotóxicos (CTL) específicos (GILBOA, 2004). A transfecção passiva não é um método tóxico para as células, pois necessita apenas da incubação com o RNA. No entanto, possui baixa eficiência devido à rápida degradação deste ácido ribonucléico por nucleases.

A técnica de lipofecção é baseada na utilização de lipossomos, capazes de transportar o RNA para dentro das células. Os lipossomos são composições lipídicas de natureza variada, podendo ser formados por lipídeos aniônicos, catiônicos, neutros ou por combinações destes. A característica que faz dos lipossomos uma ferramenta para transportar nucleotídeos às células é a sua capacidade de interação, entre si e com a água, quando expostos ao meio aquoso, promovendo, assim, a formação de bicamadas fechadas. No caso das formulações catiônicas, os lipídeos interagem espontaneamente com o RNA, de carga negativa, por forças iônicas, para formação dos complexos de transfecção, de forma que o RNA fique no interior da bicamada lipídica formada. Além de facilitar a transferência de nucleotídeos através da membrana celular, os lipossomos catiônicos protegem-nos da degradação enzimática na cultura celular (LASIC e PAPAHADJOPOULOS, 1995). Em estudos realizados por microscopia eletrônica, o grupo de Lappalainen et al. (1997) mostrou que o principal mecanismo de internalização dos complexos formados por lipossomos catiônicos e oligonucleotídeos foi a endocitose. Entretanto, o grupo não excluiu o mecanismo de fusão direta dos complexos à membrana 
plasmática (LAPPALAINEN et al., 1997). Ao escolher a lipofecção como método de transporte de RNA às células, deve-se tomar um cuidado especial durante a seleção do agente de transfecção, pois os lipídeos são, frequentemente, tóxicos para as células e requerem uma boa padronização nos protocolos de transfecção. Sua aplicação clínica é um tanto limitada e depende do agente de transfecção usado. Ainda assim, este é um método muito eficiente para "sensibilizar" as DCs (BOCZKOWSKI e NAIR, 2010).

A eletroporação também tem sido descrita como um excelente método para introduzir RNA na DC. Além de não necessitar de reagentes adicionais, como na lipofecção, é compatível com o uso clínico e se tornou o método de escolha para muitos pesquisadores (VAN TENDELOO et al., 2001; WANG et al., 2009; BOCZKOWSKI e NAIR, 2010). Nesta técnica, os nucleotídeos são transportados através de poros formados na membrana celular pela aplicação de pulsos elétricos de alta voltagem. Contudo, as DCs eletroporadas tornam-se frágeis e necessitam de um cuidado especial para se recuperarem do choque elétrico a que foram submetidas. Além disso, estudos mostram que este método reduz a capacidade das células produzirem IL-12, importante para resposta imune eficaz (LANDI et al., 2007). Mais recentemente, tem-se empregado o método de nucleofecção para introduzir o RNA dentro das células. Esta técnica foi, inicialmente, utilizada para inserir o DNA dentro do núcleo, e consiste num método semelhante à eletroporação, em que as células são colocadas em uma cubeta e submetidas a uma correte elétrica. A diferença é que a suspensão celular é feita em um tampão específico e os parâmetros para o pulso elétrico também são diferentes para cada tipo celular (LANDI et al., 2007; MELHEM et al., 2008).

Com base na estratégia terapêutica do uso de RNA tumoral total, nosso laboratório já obteve alguns resultados preliminares interessantes. Estes mostraram que monócitos transfectados passivamente com RNA total isolado da linhagem de adenocarcinoma de mama (SK-BR-3), e de outras linhagens tumorais, foram capazes de sensibilizar linfócitos autólogos, que se mostraram citotóxicos contra os monócitos transfectados e contra SK-BR-3. Os monócitos transfectados poderiam servir de células alvo para ensaios de avaliação da resposta celular contra células tumorais em pacientes com câncer, substituindo o uso das próprias células tumorais de pacientes. Ao mesmo tempo, estes monócitos poderiam ser utilizados também como células estimuladoras na preparação de vacinas terapêuticas (MENEZES, 
2008). Estes resultados podem ser considerados promissores, incentivando a investigação de uma resposta imune efetiva para outros tipos de neoplasias.

Um tipo de câncer bastante atrativo para a investigação e aplicação de novas estratégias imunoterapêuticas é a leucemia linfóide crônica (LLC). Um dos motivos é pela disponibilidade dessas células cancerosas no sangue periférico, não necessitando esperar que o paciente seja submetido a uma cirurgia para se ter acesso ao tumor. Além do mais, esta é uma doença de curso natural longo e progressão lenta, que pode permitir o desenvolvimento de respostas imunes contra células tumorais, desde que encontrada a estratégia correta de imunização (MAURO et al., 1999; HUS et al., 2008). O que caracteriza a LLC é o acúmulo anormal de linfócitos B monoclonais maduros e não-funcionais, no sangue periférico, medula óssea, linfonodos e outros órgãos linfóides. O perfil imunológico das células leucêmicas é definido pela expressão de CD19, CD23 e CD20 com co-expressão de CD5 (GINALDI et al., 1998; HALLEK et al., 2008).

A LLC compreende o tipo mais comum de leucemia que acomete adultos no mundo ocidental. Aproximadamente 180 mil novos casos são registrados mundialmente por ano (GINALDI et al., 1998; HALLEK et al., 2008). A causa exata da LLC ainda é desconhecida e de acordo com estudos epidemiológicos não existe associação clara com infecções virais, exposição química ou radiação (GOLDIN e SLAGER, 2007). Entretanto, sabe-se que ela está relacionada com a idade avançada. Os portadores da LLC muitas vezes exibem hipogamaglobulinemia severa e alteração na troca de classes das imunoglobulinas (lg). Como consequência destas disfunções os pacientes apresentam aumento na susceptibilidade a infecções bacterianas, o que contribui para a maior morbidade e a mortalidade desta doença (DEARDEN, 2008; HAMBLIN e HAMBLIN, 2008).

Apesar dos avanços na compreensão e tratamento dessa neoplasia, a LLC permanece incurável com o uso das terapias disponíveis no momento (DREGER et al., 2004; FADERL e KEATING, 2005; BYRD et al., 2006). Como a maioria dos pacientes possui idade avançada, o tratamento não são compatíveis com o uso de quimioterapia agressiva. Embora o transplante com células tronco hematopoiéticas possa levar à remissão completa da doença em alguns pacientes, a maioria deles apresenta recidiva (GRIBBEN et al., 2005). Isto faz com que o tempo de sobrevida varie entre períodos inferiores a 1 ano e superiores a 15 anos, dependendo também 
do estágio da doença em que o paciente se encontra (MORENO e MONTSERRAT, 2008).

Há inúmeras dificuldades para o desenvolvimento de imunoterapia para LLC, pois ela apresenta uma variedade de alterações imunológicas e imunossupressoras (ORSINI et al., 2004; DEARDEN, 2008), que ainda podem ser agravadas pela terapia convencional. Já foram descritas alterações funcionais nas células $T$, NK (do inglês, natural killer), monócitos, macrófagos, neutrófilos e, inclusive, nas DCs destes pacientes (ORSINI et al., 2003; ORSINI et al., 2004; DEARDEN, 2008). Mesmo assim, algumas estratégias terapêuticas, usando-se, por exemplo, células leucêmicas apoptóticas endocitadas pelas DCs (PALMA et al., 2008) ou mRNA tumoral transfectado em DCs autólogas (MULLER et al., 2004), mostraram resultados relevantes, que necessitam, ainda, serem aprimorados.

As reações de rejeição observadas em alguns casos de transplante de medula óssea alogenêica sugerem a existência de antígenos imunogênicos nas leucemias (GIANNOPOULOS et al., 2006). Um deles é a survivina, uma proteína inibidora de apoptose, super-expressa em uma ampla variedade de neoplasias malignas, como a LLC (DE MARIA et al., 2009). Esta proteína é essencial para sobrevivência das células cancerosas, já que possui importante papel no balanço entre proliferação celular e morte programada das células, durante o ciclo celular. 0 papel exato da survivina na cascata apoptótica ainda não foi totalmente esclarecido. Entretanto, sabe-se que ela está implicada na regulação da mitose, checkpoints de sobrevivência e adaptação das células a um microambiente desfavorável (LI et al., 1998).

A survivina pode ser encontrada em várias localizações subcelulares como nas mitocôndrias, citoplasma, núcleo e, recentemente, no espaço extracelular. Khan et al. evidenciaram que a survivina pode ser secretada pelas células tumorais, via exossomos. Observaram, ainda, que em condições de estresse havia aumento no conteúdo de survivina dos exossomos secretados pelas células tumorais. Este transporte da survivina para o meio extracelular poderia ser responsável pela maior agressividade do tumor, dificultando ou minimizando os resultados terapêuticos (KHAN et al., 2010).

$\mathrm{Na}$ LLC, observou-se que a interação entre as células leucêmicas no microambiente tumoral aumenta a expressão da survivina (ZENZ et al., 2010). A alta expressão desta proteína nas células cancerosas e concomitantemente baixa 
expressão na maioria dos tecidos normais fazem da survivina um importante alvo para terapias anti-tumorais. Geralmente, na maioria dos tecidos adultos, sua expressão é restrita à fase G2/M do ciclo celular (LOPES et al., 2005). De acordo com Zeis et al. (2003), utilizando-se o mRNA da survivina foi possível gerar uma resposta de linfócitos $\mathrm{T}$ citotóxicos capazes de lisar células hematológicas neoplásicas, mas não células hematopoiéticas normais (SCHMIDT et al., 2003; ZEIS et al., 2003). Foi observado por Nagaraj et al. (2007), que imunizando camundongos com DCs, transduzidas com vetores virais expressando survivina humana mutante, resultava na geração de linfócitos $\mathrm{T} \mathrm{CD8}^{+}$capazes de reconhecer vários epítopos derivados da survivina murina, com efeito anti-tumoral contra vários tumores testados. Além disso, os autores mostraram que não houve toxicidade às células progenitoras hematopoéticas, que também expressam survivina. Esses dados mostram que esta proteína poderia ser um alvo em potencial para se utilizar nas estratégias terapêuticas. Contudo, apenas um efeito antitumoral parcial foi conseguido, sugerindo que uma resposta direcionada a vários antígenos tumorais seria melhor opção (NAGARAJ et al., 2007).

Outro antígeno expresso pelas células leucêmicas e encontrado, também, na maioria dos tumores sólidos, como câncer de mama, é a proteína receptora de laminina imatura (OFA-iLRP), mais conhecida como proteína ribossomal SA (RPSA). Ela é um antígeno oncofetal, bastante relacionado com metástases de tumores sólidos, que funciona como um co-fator na estabilização da ligação entre a laminina e integrinas de superfície celular. Embora a variante de maior peso molecular seja encontrada em tecidos normais, a OFA-iLRP de $37 \mathrm{kDa}$ é expressa abundante e preferencialmente em muitos tipos de tumores, incluindo neoplasias hematológicas (SIEGEL et al., 2003; SIEGEL et al., 2006; BIRAGYN et al., 2007; BARSOUM et al., 2009), sendo conhecida como um importante imunógeno tumoral. Terapia com DCs utilizando essa proteína já foi estudada em pacientes com carcinoma metastático renal, indicando a presença de epítopos imunodominantes (ZELLE-RIESER et al., 2001). Além disso, Siegel et al. (2003) mostraram que DCs transfectadas com RNA da RPSA induzem uma resposta imune capaz de lisar as células tumorais hematológicas, inclusive células leucêmicas obtidas de pacientes com LLC. $O$ aperfeiçoamento desta estratégia poderia render bons resultados na imunoterapia para esta neoplasia. 
Enfim, considerando-se que os tumores não induzem uma resposta inflamatória efetiva conduzida pela ativação adequada das DCs, resultando em uma fraca e ineficiente resposta imune, a proposta de vacinas terapêuticas baseadas no uso de DCs sugere o carregamento destas células com antígenos tumorais, de forma que o sistema imune possa "enxergar" o tumor da maneira correta. Teoricamente, isto seria conseguido de forma mais eficiente, se fossem utilizadas DCs alogenêicas, derivadas de monócitos de doadores saudáveis, já que as células de pacientes têm demonstrado alterações desde os monócitos precursores das DCs. Por outro lado, a transferência de RNA tumoral total às DCs serviria de fonte ilimitada de vários antígenos tumorais, já que este nucleotídeo pode ser amplificado in vitro a partir de uma pequena amostra inicial do tumor. Além do mais o uso do RNA total minimiza o risco de escape tumoral e permite que os antígenos, conhecidos ou não, sejam processados e apresentados pelas DCs alogenêicas, em tese, no contexto de suas moléculas codificadas pelo $\mathrm{MHC}$ e no das moléculas codificadas pelo $\mathrm{MHC}$ do tumor.

Deste modo, este trabalho pretendeu amplificar e transfectar o RNA tumoral total, obtido a partir de células tumorais de pacientes com LLC, em DCs alogenêicas derivadas de doadores saudáveis. Neste aspecto, as DCs transfectadas serão avaliadas quanto a sua capacidade de estimular a resposta de linfócitos T $\mathrm{CD}^{+} \mathrm{e}$ $\mathrm{CD}^{+}$, direcionadas contra as células leucêmicas. Uma vez confirmada a capacidade de apresentação antigênica pelas DCs transfectadas e caracterizados os padrões de resposta por elas induzidos, seria possível desenhar estudos para avaliação desta abordagem em situações clínicas. Assim, sabendo-se que uma transfecção eficiente e tradução correta do mRNA nas DCs são etapas críticas para que as mesma passem a apresentar os antígenos tumorais, a princípio, estabelecemos estas condições utilizando o mRNA dos antígenos tumorais survivina e RPSA, para posteriormente aplicar os resultados obtidos ao mRNA tumoral total. 
2 OBJETIVOS 


\subsection{Geral}

Aprimorar a metodologia de transfecção de DCs alogenêicas com mRNA de antígenos tumorais (survivina e RPSA), a fim de estabelecer as condições eficazes a serem empregadas para transfecção do mRNA tumoral total, como estratégia para indução de resposta imune específica em portadores de leucemia linfóide crônica.

\subsection{Específicos}

- Obter e caracterizar células dendríticas a partir de monócitos do sangue periférico de doadores saudáveis.

- Obter e amplificar in vitro o mRNA total, obtido a partir de células tumorais de pacientes com LLC, e o mRNA dos antígenos tumorais, survivina e da RPSA.

- Realizar a transfecção do mRNA do antígeno survivina em células dendríticas de doadores saudáveis.

- Analisar a eficácia da transfecção.

- Avaliar o potencial linfo-estimulador das DCs transfectadas com mRNA através da caracterização das populações proliferando e pelo padrão de citocinas secretadas. 
3 MATERIAL E MÉTODOS 


\subsection{Casuística}

Este trabalho contou com aprovação do Comitê de Ética em Pesquisa do Instituto de Ciências Biomédicas da Universidade de São Paulo (Parecer 843/CEP). As amostras de sangue necessárias para a diferenciação em células dendríticas foram obtidas do Hospital Oswaldo Cruz, a partir de câmaras de leuco-redução de plaquetaferese, de doadores saudáveis, após a assinatura do Termo de Consentimento Livre e Esclarecido. As amostras de sangue dos pacientes com leucemia linfóide crônica (LLC) foram obtidas do Hospital Brigadeiro, após o consentimento dos mesmos. Foram estudadas duas pacientes, com idades de $74 \mathrm{e}$ 75 anos, que apresentavam diagnóstico de LLC, ainda em estágio inicial da doença e não submetidas a nenhum tipo de terapia anti-leucêmica. Foram realizadas coletas do sangue periférico das pacientes, por punção venosa, para obtenção das células tumorais e extração do RNA total. Seguem na tabela abaixo os dados dos pacientes que participaram do estudo.

Tabela 1- Características clínicas dos pacientes estudados.

\begin{tabular}{ccccccc}
\hline \hline Pacientes & Sexo & $\begin{array}{c}\text { Idade } \\
\text { atual } \\
(\text { anos })\end{array}$ & $\begin{array}{c}\text { Idade do } \\
\text { diagnóstico }\end{array}$ & $\begin{array}{c}\text { Leucócitos } \\
\left(\mathrm{mm}^{3}\right)\end{array}$ & $\begin{array}{c}\text { Histórico de } \\
\text { infecções }\end{array}$ & $\begin{array}{c}\text { Câncer na } \\
\text { família }\end{array}$ \\
\hline 1 & $\mathrm{~F}$ & 74 & 72 & 34.000 & Herpes & Desconhecido \\
2 & $\mathrm{~F}$ & 75 & 75 & 29.800 & Negativo & Desconhecido \\
\hline \hline
\end{tabular}

\subsection{Isolamento de monócitos para diferenciação em DCs in vitro}

Os monócitos foram separados do produto presente nas câmaras de leucoredução (LRS) por centrifugação em gradiente de densidade e aderência ao plástico. Para purificação das células mononucleares, o material diluído em solução salina tamponada com fosfato (PBS), na proporção de 1:1, foi colocado em tubo plástico cônico de $50 \mathrm{~mL}$, sobre $12 \mathrm{~mL}$ de Ficoll-Paque Plus (GE Healthcare). O material foi centrifugado a $900 \mathrm{~g}$, a $18 \stackrel{\circ}{\circ}$, por $30 \mathrm{~min}$. A camada de células mononucleares formada foi retirada, colocada em outro tubo juntamente com RPMI e centrifugada a $600 \mathrm{~g}$ por $10 \mathrm{~min}$. As células foram lavadas por mais duas vezes a 300 e a $200 \mathrm{~g}$, respectivamente, para eliminação das plaquetas. $O$ sedimento foi coletado, as 
células quantificadas, ressuspendidas em meio RPMI-1640 suplementado com 10\% de soro fetal bovino (R10) ou no meio de cultura livre de soro, AIM-V (Gibco BRL) e colocadas em cultura, em garrafas T75, numa concentração final de $3 \times 10^{8} / \mathrm{ml}$. As células foram mantidas na estufa com atmosfera contendo $5 \%$ de $\mathrm{CO}_{2}$ e saturada com água, a $37^{\circ} \mathrm{C}$ para aderência por 2 horas ou overnight.

Após a incubação, as células não aderentes presentes no sobrenadante foram removidas, quantificadas e congeladas em soro fetal bovino (SFB) e DMSO (9:1) numa concentração final em torno de $1 \times 10^{7}$ células $/ \mathrm{ml}$. As células aderentes foram mantidas em cultura por cinco dias em meio R-10 ou AIM-V acrescido de 50 $\mathrm{ng} / \mathrm{mL}$ de IL-4 e 50 ng/mL de GM-CSF para a diferenciação dos monócitos em DCs. Após esse período, as células foram ativadas pela adição de coquetel de ativação, levando a uma concentração final de $10 \mathrm{ng} / \mathrm{mL}$ de TNF- $\alpha, 10 \mathrm{ng} / \mathrm{mL}$ de IL1- $\beta$, $10 \mathrm{ng} / \mathrm{mL}$ de IL-6 e $1 \mu \mathrm{g} / \mathrm{mL}$ de prostaglandina E2. No sétimo dia, estas foram removidas utilizando-se RPMI-1640 gelado, lavadas e sua viabilidade testada por exclusão com Azul de Trypan 0,4\% (Sigma). As células viáveis foram contadas e ressuspendidas com volume de meio adequado para os ensaios subseqüentes. No caso dos ensaios que envolveram a utilização de monócitos e células dendríticas imaturas, estas foram submetidas a um banho de gelo por 10 minutos e com auxílio de cell scraper, retiradas da placa no dia zero e no quinto dia da cultura, respectivamente.

\subsection{Avaliação do fenótipo de membrana das DCs por citometria de fluxo}

Para determinação do fenótipo de membrana de monócitos, DCs imaturas e maduras, essas células foram marcadas com anticorpos monoclonais comerciais para as seguintes moléculas de membrana: CD1a (molécula apresentadora de lipídeos e glicolipídeos), CD11c (marcador de DCs mielóides), CD123 (marcador de DCs linfóides), CD14 (marcador de linhagem monocítica mielóide), CD80 e CD86 (B7-1 e B7-2, moléculas co-estimuladoras), CD83 (marcador de DCs ativadas/maduras), CD40 (molécula co-estimuladora) e HLA-DR (molécula do MHCII, expressa em APCs profissionais) (Tabela 2). 
Tabela 2 - Dados referentes aos anticorpos murinos usados para citometria de fluxo. Tabela de anticorpos monoclonais, indicando a especificidade do anticorpo (molécula), o clone, o isotipo e a cor, utilizados para citometria de fluxo de monócitos e células dendríticas. Todos os anticorpos foram adquiridos da BD Biosciencies.

\begin{tabular}{|c|c|c|c|}
\hline Molécula & Clone & Isotipo & Cor \\
\hline CD14 & M5E2 & $\lg G 2 a, k$ & FITC \\
\hline CD14 & M5E2 & $\lg G 2 a, k$ & $\mathrm{PE}$ \\
\hline HLA-DR & L243 (G46-6) & $\lg G 2 a, k$ & APC \\
\hline HLA-DR & L243 (G46-6) & $\lg G 2 a, k$ & PE-Cy5 \\
\hline CD11c & B-ly6 & $\lg G 1, \mathrm{~K}$ & $P E$ \\
\hline CD11c & B-ly6 & $\lg \mathrm{G} 1, \mathrm{~K}$ & PE-Cy5 \\
\hline CD1a & $\mathrm{HH} 149$ & $\lg G 1, \mathrm{~K}$ & PE \\
\hline CD123 & $9 F 5$ & $\lg G 1, \mathrm{k}$ & PE-Cy5 \\
\hline CD80 & L307.4 & $\lg G 1, \mathrm{~K}$ & PE-Cy 5 \\
\hline CD86 & 2331 (FUN-1) & $\lg \mathrm{G} 1, \mathrm{~K}$ & PE \\
\hline CD40 & $5 \mathrm{C3}$ & $\lg \mathrm{G} 1, \mathrm{k}$ & FITC \\
\hline CD40 & $5 \mathrm{C3}$ & $\lg G 1, \mathrm{~K}$ & PE \\
\hline CD40 & $5 C 3$ & $\lg G 1, \mathrm{~K}$ & PE-Cy5 \\
\hline CD83 & HB15e & $\lg G 1, \mathrm{~K}$ & PE-Cy 5 \\
\hline CD83 & HB15e & $\lg G 1, \mathrm{~K}$ & APC \\
\hline
\end{tabular}

Após a contagem em câmara de Neubauer, alíquotas de 1 a $2 \times 10^{5}$ células, obtidas das culturas, foram colocadas em tubos plásticos (Eppendorf) de 1,5 mL e lavadas três vezes, por centrifugação, a $17946 \mathrm{~g}$, a $4 \stackrel{\circ}{\circ} \mathrm{C}$ por $10 \mathrm{~s}$, com $300 \mu \mathrm{L}$ de tampão para citometria PBS-BSA (PBS suplementado com $0,5 \%$ de soroalbumina bovina e $0,02 \%$ de azida sódica). Ao sedimento obtido foram adicionados os anticorpos específicos para os marcadores de interesse. As células foram incubadas ao abrigo da luz por $20 \mathrm{~min}$ a $4 \stackrel{\circ}{\circ}$. Após esse período, adicionou-se $200 \mu \mathrm{L}$ de PBSBSA e o material foi lavado duas vezes nas mesmas condições. As células marcadas foram ressuspendidas com $300 \mu \mathrm{L}$ de PBS-BSA contendo $2 \%$ de formaldeído para a fixação das mesmas. A seguir, as amostras foram adquiridas no citômetro de fluxo (FACSCalibur) com o software CellQuest (BD Biosciences) e os dados obtidos foram analisados com a utilização do software FlowJo 7.2.5 (Tree Stars Inc.). 


\subsection{Marcação de moléculas intracelulares}

Para avaliar a expressão das proteínas intracelulares, como a survivina, antígeno tumoral usado para transfectar as DCs, primeiramente, as células foram marcadas da maneira convencional para as moléculas extracelulares, como descrito acima. Após a marcação com os anticorpos de interesse, as células foram lavadas 3 vezes com PBS, desprezando-se o sobrenadante e adicionando-se 100 $\mu \mathrm{L}$ da solução de fixação e permeabilização de membrana (BD Cytofix/Cytoperm ${ }^{\mathrm{TM}}$ ). Após 30min de incubação à temperatura ambiente, no escuro, acrescentou-se $400 \mu \mathrm{L}$ de PBS, para interromper a reação de permeabilização, centrifugando-se a suspensão celular a $17946 \mathrm{~g}$, a $10{ }^{\circ} \mathrm{C}$ por $10 \mathrm{~s}$. A seguir foram adicionados $130 \mu \mathrm{L}$ de solução de paraformaldeído 1\%-Tween 0,5\% em cada amostra, homogeneizando-se bem. Após mais 30min de incubação, as células foram lavadas com 400 $\mu \mathrm{L}$ de PBS gelado e ao sedimento formado foram adicionados $3 \mu \mathrm{L}$ do anticorpo anti-survivina (R\&D). Incubaram-se as células à temperatura ambiente por uma hora, no escuro, seguindo-se por uma lavagem com $400 \mu \mathrm{L}$ de PBS gelado. Por fim adicionaram-se $300 \mu \mathrm{L}$ de PBS-BSA-formaldeído $2 \%$ em cada amostra, para leitura no citômetro de fluxo.

\subsection{Método de análise dos monócitos, DCs imaturas e maduras}

Para analisar as moléculas de membrana presentes na superfície dos monócitos (dia 0 da cultura), delimitou-se um gate em tamanho (FSC - forward scatter) por granulosidade (SSC - side scatter), na população que possuía estes parâmetros característicos dos monócitos, e avaliaram-se os marcadores de interesse na população de células que dentro deste gate, eram CD14+ (Figura 1).

Um conjunto de anticorpos para marcadores celulares de linfócitos T (CD3), B (CD19), monócitos e macrófagos (CD14) e células NK (CD56), nomeados lineage, foi usado nos primeiros experimentos, para exclusão dessas células nas análises fenotípicas das DCs. Entretanto, foi observado que o gate de tamanho por granulosidade, já excluía estas células, que tendem a ser menores e menos granulosas do que as DCs, com exceção dos monócitos e macrófagos. Assim, no caso da fenotipagem de DCs imaturas (quinto dia) e maduras (sétimo dia), passouse a considerar as células que, dentro do gate de tamanho por granulosidade 
característicos, eram HLA-DR ${ }^{+}$CD14- (Figura 1), de forma a excluir monócitos e macrófagos da análise.
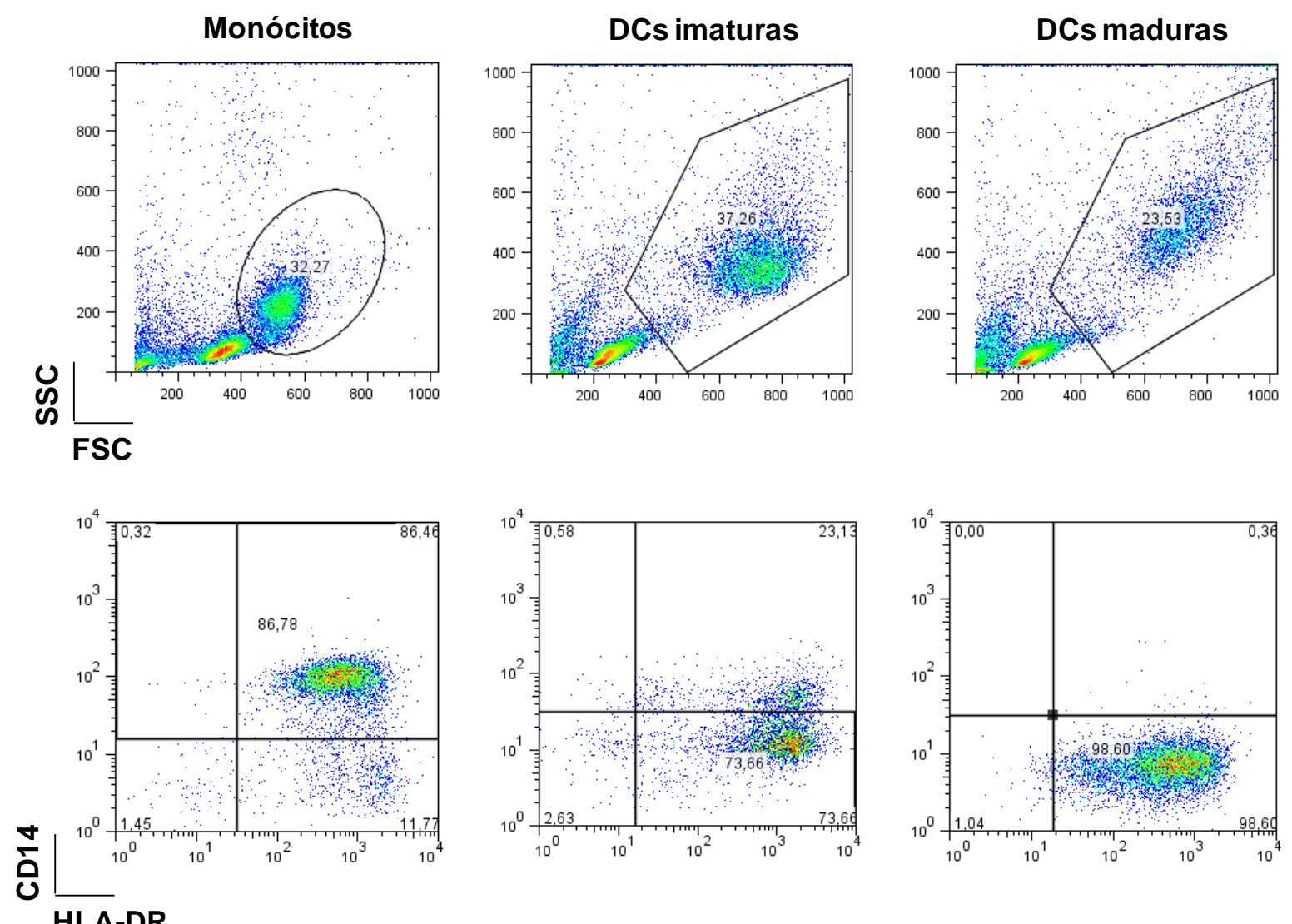

HLA-DR

Figura 1 - Gráficos ilustrando o modo de análise de monócitos, DCs imaturas e DCs maduras para caracterização fenotípica por citometria de fluxo. Os monócitos, DCs imaturas e maduras foram retirados da cultura para diferenciação em DCs nos dias zero, cinco e sete, respectivamente, para caracterização dos marcadores de superfície, por citometria de fluxo. Acima: Gráficos pseudo-coloridos de tamanho (FSC) por granulosidade (SSC), em que se delimitou um gate para seleção da população com tamanho e granulosidade característicos das células em análise. Abaixo: Gráficos pseudo-coloridos de CD14 por HLA-DR dentro dos gates de tamanho e granulosidade característicos das células em análise, em que se delimitou, no caso de monócitos, gate para as células CD14 ${ }^{+}$e, no caso de DCs imaturas e maduras, gate para as células HLA-DR ${ }^{+}$CD14, nos quais as análises fenotípicas foram realizadas.

\subsection{Transfecção da linhagem celular 293-T com vetor plasmideal pLV-EGFP e mRNA da EGFP}

Antes de iniciar as padronizações da transfecção em DCs, com o plasmídeo pLV, o qual possui a região codificadora da proteína fluorescente EGFP (do inglês, enhanced green fluorescent protein)., ou mRNA do EGFP, realizou-se a transfecção na linhagem celular 293-T, para verificar se esta construção pLV-EGFP e o mRNA 
transcrito in vitro (Item 3.11), eram funcionais. O vetor plasmideal pLV-EGFP e a linhagem celular 293-T foram doação da Prof ${ }^{a}$. Dr ${ }^{\mathrm{a}}$ Mari Cleide Sogayar do Instituto de Química da Universidade de São Paulo (IQ/USP).

Cerca de 16 a 24 horas antes da transfecção, as células 293-T (linhagem celular de rim humano embrionário) foram plaqueadas em placas de doze poços

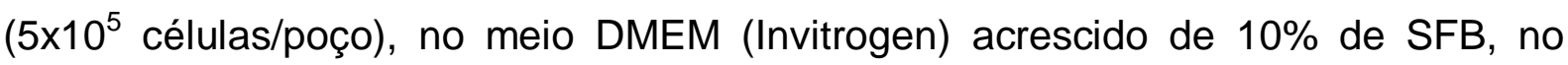
volume final de $0,75 \mathrm{~mL}$. Utilizou-se $1,2 \mu \mathrm{g}$ do vetor pLV-EGFP ou mRNA da EGFP, que foi diluído em $75 \mu \mathrm{L}$ de meio DMEM sem soro. Simultaneamente, em outro tubo, $5 \mu \mathrm{L}$ do reagente de lipofecção (Lipofectamina 2000 - Invitrogen) foram diluídos em $75 \mu \mathrm{L}$ de meio DMEM sem soro para cada reação de transfecção. Misturou-se o conteúdo dos dois tubos e incubou-se a mistura por 20min. Após este período, adicionou-se a mistura lipossomos/DNA às células. $O$ meio de cultura foi trocado após 5 horas da transfecção. As células foram observadas em microscópio de fluorescência e por citometria de fluxo, com 24 e 48 horas.

\subsection{Eletroporação das DCs}

Para eletroporação, dois procedimentos diferentes foram realizados com as DCs imaturas (iDCs), conforme descrito a seguir.

Protocolo 1: As iDCs foram removidas das placas de cultura, conforme descrito no item 3.2, e lavadas 2 vezes em $10 \mathrm{~mL}$ de solução de glicose $5 \%$ a $290 \mathrm{~g}$ por 5 min. Em seguida, $10^{7}$ células foram ressuspendidas em 0,2 ou $1 \mathrm{~mL}$ da mesma solução, e a suspensão celular transferida para uma cubeta de $4 \mathrm{~mm}$ de espessura (Bio-

Rad). À suspensão celular presente na cubeta adicionaram-se $20 \mu \mathrm{g}$ do plasmídeo pLV-EGFP. Também foi utilizada uma quantidade de $10^{6}$ células ressuspendidas em $0,5 \mathrm{~mL}$ de glicose $5 \%$, as quais foram colocadas na cubeta, com adição de $1 \mu \mathrm{g}$ do plasmídeo pLV-EGFP. As células foram transfectadas no Eletroporador Gene Pulser II (Bio-Rad), com os seguintes parâmetros físicos: 1 pulso a 300 V e 25 ou $150 \mu \mathrm{F}$. Após o pulso, incubaram-se as células em $2 \mathrm{~mL}$ de solução de relaxamento $(\mathrm{KCl} 100$ $\mathrm{mM}, \mathrm{NaCl} 3 \mathrm{mM}$, EDTA 1,25 mM, PIPES $10 \mathrm{mM}$ e ATP 0,5 mM) durante 2 min à temperatura ambiente. Após esta incubação, as células foram centrifugadas a $290 \mathrm{~g}$ 
por 10 min, ressuspendidas em meio R10 ou AIM-V e plaqueadas em placas de 6 poços adicionando-se IL-4, GM-CSF e o coquetel de citocinas de ativação (Item 3.2).

Protocolo 2: As iDCs foram removidas das placas de cultura, conforme descrito no item 3.2, e lavadas 2 vezes com 10mL de RPMI, sem soro e sem antibióticos, a 290 g por 10 min. Em seguida, $10^{7}$ células foram ressuspendidas em 0,5 mL de RPMI e transferidas para as cubetas de $4 \mathrm{~mm}$. Após a incubação no gelo durante $10 \mathrm{~min}$, acrescentaram-se $20 \mu \mathrm{g}$ do plasmídeo pLV-EGFP à cubeta contendo a suspensão celular. As células foram transfectadas no Eletroporador Gene Pulser II (Bio-Rad), com os seguintes parâmetros físicos: 2 pulsos a $300 \mathrm{~V}$ e $25 \mu \mathrm{F}$. Incubaram-se as células durante $10 \mathrm{~min}$ no gelo e procedeu-se a 3 lavagens com $10 \mathrm{~mL}$ de PBS, a $290 \mathrm{~g}$ por $10 \mathrm{~min}$ a $4^{\circ} \mathrm{C}$. As células, então, foram colocadas em placas de 6 poços em meio R10 ou AIM-V, adicionando-se IL4, GM-CSF e o coquetel de citocinas de ativação (Item 3.2).

Para os dois protocolos testados, imediatamente após o pulso, uma alíquota das células foi corada com azul de Trypan 0,4\% (Sigma) para observar se houve formação de poros na membrana celular durante a eletroporação. Caso isto tivesse acontecido, observavam-se células azuis pela incorporação do corante. A eficiência da transfecção foi avaliada pela porcentagem de células positivas para a proteína fluorescente EGFP, após 24 e/ou 48 horas, por citometria de fluxo.

\subsection{Lipofecção das DCs}

Para a lipofecção das células, optou-se por utilizar o agente de transfecção Lipofectamine ${ }^{\mathrm{TM}} 2000$ (Invitrogen), disponível no laboratório da Prof ${ }^{\mathrm{a}}$. Dr ${ }^{\mathrm{a}}$ Mari Cleide Sogayar do (IQ/USP), onde estes experimentos foram realizados inicialmente. Neste caso, dois protocolos diferentes foram testados, sendo o protocolo 1 aplicado à transfecção com DNA e o protocolo 2 aplicado tanto para DNA quanto para mRNA, conforme descrito abaixo.

Protocolo 1: O agente de transfecção e o plasmídeo pLV-EGFP foram diluídos, separadamente, em meio DMEM para volume final de $100 \mu \mathrm{L}$. Essas diluições foram incubadas por 5 min à temperatura ambiente. Após a incubação, misturaram-se as 
soluções diluídas, com nova incubação por 20min à temperatura ambiente, possibilitando a formação dos complexos lipossomo/DNA. Estes complexos foram dispensados no meio de cultivo das iDCs (quinto ou sétimo dia de cultura) ou mDCs (sétimo dia de cultura) plaqueadas $\left(10^{6}\right.$ células/poço de uma placa de 24 poços) momentos antes da transfecção. Logo após, foi acrescentado IL-4, GM-CSF e as citocinas do coquetel de ativação (Item 3.2). A concentração de DNA recomendada pelo fabricante para os ensaios iniciais de transfecção é de 1 a $5 \mu \mathrm{g}$. Logo, optou-se por testar 1, 2 e $4 \mu \mathrm{g}$ de DNA, utilizando uma relação entre DNA e agente de transfecção de 1:8.

Protocolo 2: DCs imaturas foram retiradas da cultura no quarto dia e plaqueadas em placas de 24 poços, com $2 \times 10^{5}$ células/poço, em $500 \mu \mathrm{L}$ de RPMI, sem SFB e antibióticos ou de AIM-V, acrescidos das citocinas IL-4 e GM-CSF. Estas células foram deixadas aderindo à placa de 24 poços, overnight, e no dia seguinte, foi realizada a transfecção. O agente de transfecção e o plasmídeo pLV-EGFP (ou o mRNA dos antígenos tumorais) foram diluídos, separadamente, em $50 \mu \mathrm{L}$ do meio Opti-MEM (Invitrogen), incubando-se as soluções por 5 min à temperatura ambiente. Após a incubação, misturaram-se as soluções diluídas, com nova incubação por 30min à temperatura ambiente, possibilitando a formação dos complexos de transfecção. Estes complexos foram dispensados no meio de cultivo das iDCs (quinto dia de cultura) e incubados durante 7 horas, quando foi adicionado SFB (no caso da transfecção ser realizada no meio RPMI) e as citocinas do coquetel de ativação (Item 3.2). Diversas proporções entre o DNA e mRNA com agente de transfecção foram testadas: $0,8 \mu \mathrm{g}$ de DNA (ou mRNA) para 2, 2,6 e 3,2 $\mu \mathrm{L}$ de agente de transfecção; 0,6, 1 e 1,4 $\mu$ g de DNA (ou mRNA) para respectivamente 1,8, 3 e $4,2 \mu \mathrm{L}$ de agente de transfecção.

A eficiência da transfecção com DNA foi avaliada pela porcentagem de células positivas para a proteína fluorescente EGFP, após 24 e/ou 48 horas, por citometria de fluxo, ou avaliadas por microscopia de fluorescência. No caso das células transfectadas com mRNA, avaliou-se, por citometria de fluxo, tanto a freqüência de células quanto o aumento da expressão do antígeno transfectado. 


\subsection{Método de análise das DCs transfectadas}

De maneira geral, para avaliação da eficiência de transfecção e para análise fenotípica das células transfectadas, delimitou-se um gate em tamanho e granulosidade, na população que possuía estes parâmetros característicos de DCs, e avaliaram-se os marcadores de interesse na população de células que dentro deste gate eram $\mathrm{HLA}_{-} \mathrm{R}^{+} \mathrm{CD} 14^{-}$. Eventualmente, a análise foi realizada na

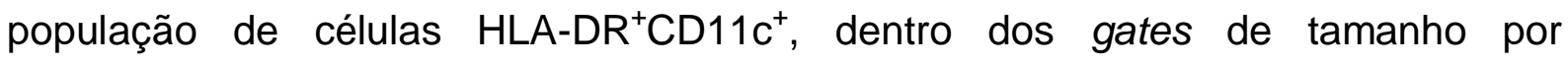
granulosidade (Figura 2A).

No caso das células submetidas à eletroporação, não foi realizado gate de tamanho por granulosidade, pois como este método altera a morfologia das células, fica difícil estabelecer a população característica de DC. Por tanto, as células EGFP ${ }^{+}$ foram avaliadas consideraram-se o gate na população HLA-DR ${ }^{+}$CD11 ${ }^{+}$(Figura 2C).

Já para as DCs transfectadas com mRNA do antígeno survivina, avaliaram-se as células que no gate SSC por FSC eram CD14- e HLA-DR ${ }^{+}$, e nesta população foram delimitados, nos histogramas, gates na intersecção entre as células transfectadas e as células com expressão basal da survivina. Para calcular a eficiência da transfecção, subtraíram-se os valores da porcentagem de células transfectadas pelos valores da porcentagem de expressão basal da survivina (Figura 2B). 
A
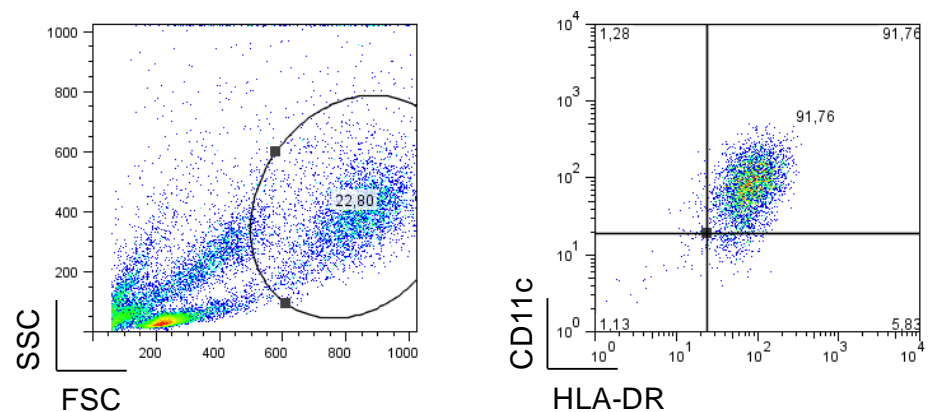

B

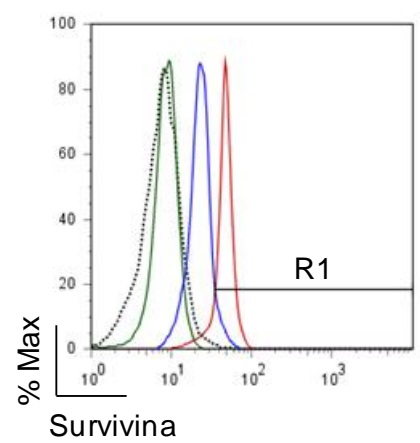

DCs sem tratamento

DCs+lipofectamina

Expressão endógena de survivina

DCs tranfectadas com mRNA

C
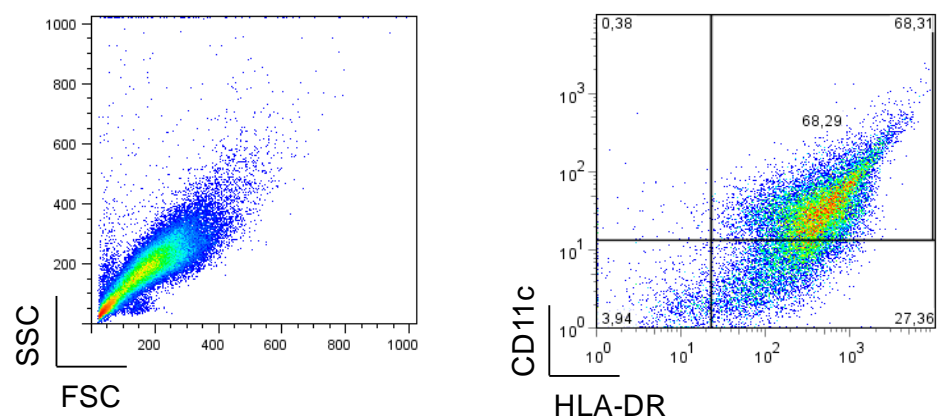

Figura 2 - Gráficos ilustrando o modo de análise das DCs transfectadas com DNA e RNA por citometria de fluxo. As DCs transfectadas foram avaliadas após 24 e/ou 48 horas da transfecção com o plasmídeo pLV-EGFP ou mRNA da survivina. (A) Modo de análise geral da transfecção. À esquerda: Gráfico pseudo-colorido de tamanho (FSC) por granulosidade (SSC), em que se delimitou um gate para seleção da população com tamanho e granulosidade característicos das DCs. À direita: Gráfico pseudo-colorido de CD11c por HLA-DR dentro do gate de tamanho e granulosidade, no qual as análises da eficiência de transfecção foram realizadas. (B). Histograma ilustrando o modo de análise das DCs trasnfectadas com mRNA da survivina. O gate R1 foi feito na intersecção entre as células transfectadas (linha vermelha) e as células sem tratamento com expressão basal da survivina (linha azul). Este gate foi delimitado na população de células que dentro do gate SSCxFSC eram CD14 e HLA-DR ${ }^{+}$. (C) Gráfico pseudo-colorido ilustrando o modo de análise das células eletroporadas com pLV-EGFP. À esquerda: Gráfico de tamanho por granulosidade, em que se delimitou o gate CD11c ${ }^{+} H L A-D R^{+}$(à direita), utilizado para avaliar as células EGFP ${ }^{+}$. 


\subsection{Preparação dos moldes de cDNA da EGFP, RPSA e Survivina para síntese de mRNA por transcrição in vitro}

\subsubsection{Clonagem do gene EGFP no plasmídeo pGEM-T Easy}

Para obtenção do molde de cDNA do EGFP que seria utilizado em reações de síntese do mRNA deste gene, foi necessário clonar o EGFP em um vetor que possuísse os promotores das enzimas polimerases T7 ou SP6.

A região codificadora da proteína EGFP foi obtida a partir da digestão do vetor pLPCX-EGFP com a enzima de restrição EcoRI (Fermentas). O fragmento obtido ( 730 pb) foi purificado após fracionamento em gel de agarose, utilizando-se o kit QIAquick PCR purification (Qiagen). O fragmento purificado foi quantificado e teve sua pureza avaliada espectrofotometricamente através da relação $A_{260 n m} / A_{280 \mathrm{~nm}}$, considerando-se uma relação superior a 1,8, como aceitável.

O plasmídeo pGEM-T Easy foi linearizado com a enzima de restrição EcoRI (Fermentas) para posterior clonagem da região codificadora da proteína EGFP. O vetor PGEM-T Easy linearizado foi desfosforilado com a enzima fosfatase alcalina de camarão (1U) (SAP - Shrimp Alkaline Phosphatase Fermentas) a $37^{\circ} \mathrm{C}$ por $30 \mathrm{~min}$, seguida pela inativação da enzima a $75^{\circ} \mathrm{C}$ por $5 \mathrm{~min}$. O vetor clivado e desfosforilado foi fracionado através de uma eletroforese em gel de agarose $1 \%$ e purificado a partir do gel através do kit QIAquick PCR purification (Qiagen). O fragmento purificado foi quantificado, tendo seu grau de pureza determinado espectrofotometricamente, como descrito anteriormente.

Para subclonagem do inserto EGFP no vetor pGEM-T Easy, seguiu-se com a reação de ligação vetor-inserto através da utilização da enzima T4 DNA Ligase (5 unidades Weiss) (Fermentas). A reação de ligação foi incubada a $16^{\circ} \mathrm{C}$ por 3 horas para o anelamento entre as extremidades coesivas do inserto e vetor e, em seguida, a $22{ }^{\circ} \mathrm{C}$ por 22 horas para ligação entre os fragmentos. Ao término desse período a enzima foi inativada a $65 \stackrel{\circ}{\circ}$ por $10 \mathrm{~min}$.

Alíquotas das reações de ligação foram usadas para transformação de bactérias Escherichia coli (XL1 Blue) por eletroporação. O eletroporador foi ajustado conforme o manual do aparelho para $2.800 \mathrm{~V}$, aplicando-se o pulso e, logo depois, adicionando $1 \mathrm{~mL}$ de meio Luria Bertani (LB). As bactérias foram incubadas a $37^{\circ} \mathrm{C}$ 
sob agitação de 200-250 rpm, por 1 hora. As bactérias transformadas foram plaqueadas em meio LB-ágar 1,5\% com ampicilina $(75 \mu \mathrm{g} / \mathrm{mL})$. As placas foram incubadas a $37^{\circ} \mathrm{C}$ até o dia seguinte (cerca de 16-20 horas). As bactérias recombinantes foram inoculadas em meio LB contendo $75 \mu \mathrm{g} / \mathrm{mL}$ de ampicilina e incubadas em estufa a $37^{\circ} \mathrm{C}$ por 16 horas. Mini-preparações de DNA plasmideal das colônias recombinantes obtidas foram feitas utilizando o Kit GeneJet Miniprep kit (Fermentas), segundo orientações do fabricante.

Para verificar a clonagem do gene EGFP no vetor pGEM-T Easy, o que geraria 0 vetor pGEM-T Easy-EGFP, foi feita a digestão dos plasmídeos recombinantes, purificados, com as enzimas de restrição Ncol, Sall, Pstl e HindllI (Fermentas). Os produtos das digestões foram analisados em gel de agarose 1\%, corado com brometo de etídio $(0,5 \mu \mathrm{g} / \mathrm{mL})$ e visualizados com transluminador UV. Os fragmentos esperados para a digestão de cada plasmídeo recombinante obtido, caso a fase de leitura do gene EGFP esteja na orientação relativa ao promotor SP6 (pGEM-T Easy-EGFP SP6), estão representados na tabela abaixo (Tabela 3).

Tabela 3 - Tamanho dos fragmentos de DNA esperados, após a digestão do vetor pGEM-T Easy-EGFP, caso o gene EGFP esteja clonado no sentido do promotor SP6, com as enzimas de restrição EcoRI, Ncol, Sall, Pstl e Hindlll.

\begin{tabular}{ccc}
\hline \hline Vetor & Enzimas de restrição & Tamanho dos fragmentos $(\mathbf{p b})$ \\
\hline pGEM T Easy-EGFP & EcoRI & 3000 e 730 \\
& Ncol/HindlII & 3700 \\
& Sall/HindllI & 3000 e 730 \\
& Pstl/HindllI & 3000 e 730 \\
\hline \hline
\end{tabular}

\subsubsection{Extração do DNA plasmideal e digestão dos clones de cDNA do RPSA e survivina}

Para se obter o cDNA dos antígenos RPSA e Survivina, optou-se por utilizar clones disponíveis na MGC (Mammalian Gene Collection Full-Length Clones). Foram adquiridas as bactérias recombinantes contendo a região codificadora completa (CDS) da survivina clonada no vetor de expressão pOTB7 (cDNA clone MGC:8592 IMAGE:2961114, Invitrogen), e as bactérias contendo a CDS completa do RPSA, ou OFA-iLRP, clonada no vetor de expressão pCMV-SPORT6 (cDNA clone MGC:17122 IMAGE:3446816, Invitrogen). As bactérias recombinantes contendo esses plasmídeos foram semeadas em placas de Petri contendo meio LB-ágar acrescido 
de $75 \mu \mathrm{g} / \mathrm{mL}$ de cloranfenicol ou $75 \mu \mathrm{g} / \mathrm{mL}$ de ampicilina, referentes à marca de resistência dos plasmídeos pOTB7-survivina e pCMV-SPORT6-RPSA, respectivamente. Após a incubação em estufa a $37^{\circ} \mathrm{C}$ durante 18 horas, algumas colônias foram inoculadas em meio LB líquido acrescido dos antibióticos especificados anteriormente e deixadas sob agitação (250 rpm). Passadas 18 horas de incubação, a extração do DNA plasmideal das colônias recombinantes obtidas foi realizada utilizando o Kit GeneJet Miniprep kit (Fermentas), segundo orientações do fabricante.

Para verificar a orientação dos insertos clonados com relação aos promotores T7 e SP6 presente nos vetores, digeriu-se uma alíquota dos plasmídeos recombinantes purificados usando as enzimas de restrição Ncol, Smal, e a codigestão com as enzimas de restrição EcoRI/Xhol (Fermentas) para o pOTB7survivina. Já o pCMV-SPORT6-RPSA foi digerido com Hindlll, Ncol, e co-digerido com as enzimas de restrição Notl/Sall (Fermentas), assim com indicado pelo fabricante. Para as reações de digestão foram usadas $10 \mathrm{U}$ da enzima de restrição $(10 U / \mu L)$ com o seu tampão correspondente na concentração final 1x. As reações foram incubas a $37^{\circ} \mathrm{C}$ por $30 \mathrm{~min}$. Os produtos das digestões foram analisados em gel de agarose $1 \%$, que posteriormente foi corado com brometo de etídio $(0,5$ $\mu \mathrm{g} / \mathrm{mL}$ ) e visualizado em um transluminador UV. Os fragmentos esperados para a digestão de cada plasmídeo recombinante obtido estão representados na tabela abaixo (Tabela 4).

Tabela 4 - Tamanho dos fragmentos de DNA esperados, após a digestão dos vetores pOTB7survivina e pCMV-SPORT6-RPSA, com as enzimas de restrição Ncol, Smal e EcoRI/Xhol, e com as enzimas Hindlll, Ncol e Notl/Sall, respectivamente, caso o EGFP esteja clonado no sentido do promotor SP6.

\begin{tabular}{ccc}
\hline \hline Vetores & Enzimas de restrição & Tamanho dos fragmentos (pb) \\
\hline pOTB7-survivina & Ncol & 2694 e 774 \\
& Smal & 2560 e 908 \\
& EcoRI/Xhol & 1815 e 1653 \\
pCMV-SPORT6- & & \\
RPSA & HindllI & 4601 e 830 \\
& Ncol & 4361 e 1072 \\
& Notl/Sall & 4396 e 1037 \\
\hline \hline
\end{tabular}




\subsection{Transcrição in vitro}

Para a transcrição in vitro dos cDNAs da Survivina, RPSA e EGFP, primeiramente, efetuou-se a linearização dos vetores com enzimas de restrição que cortassem a 3' do inserto clonado (Figura 3). Para os vetores pOTB7-survivina e pCMV-SPORT6-RPSA, a linearização foi realizada através da digestão dos mesmos, a $37^{\circ} \mathrm{C}$ por 1 hora, com as enzimas de restrição Bglll e Xhol (Fermentas), respectivamente, de acordo com as instruções do fabricante. A linearização do EGFP foi feita com a enzima EcoRI. Em seguida os fragmentos linearizados foram purificados com o kit QIAquick PCR Purification (Qiagen), como recomendado pelo fabricante. O cDNA foi eluído em $50 \mu \mathrm{L}$ do tampão de eluição $(\mathrm{EB})$ do kit, sendo então quantificado pelo espectrofotômetro NanoDrop ND-1000 no comprimento de onda de $260 \mathrm{~nm}$. Adicionalmente, uma alíquota foi analisada por eletroforese em gel de agarose $1 \%$, a fim de observar se houve digestão completa.

Para a reação de transcrição in vitro foi preparada uma mistura de nucleotídeos (NTPs) composta por ATP, CTP e UTP a $10 \mathrm{mM}$ e GTP a $1 \mathrm{mM}$ (Invitrogen). Desta mistura utilizaram-se $10 \mu \mathrm{L}$ para uma concentração final de $2 \mathrm{mM}$ de ATP, CTP e UTP e 0,2 mM de GTP, 2,5 $\mu \mathrm{L}$ da estrutura análoga do cap a $10 \mathrm{mM}$ (7mG(ppp)G RNA Cap Structure Analog, New England BioLabs), DTT (Invitrogen) para uma concentração final de $5 \mathrm{mM}, 50 \mathrm{U}$ do Inibidor de RNAse $(40.000 \mathrm{U} / \mathrm{mL}$, New England BioLabs), 30U da enzima SP6 RNA Polimerase (20.000U/mL, New England BioLabs) com seu tampão na concentração final $1 x$ e $1 \mu \mathrm{g}$ de cDNA linearizado, completando o volume da reação para $50 \mu \mathrm{L}$ com água tratada com DEPC. A reação foi incubada a uma temperatura de $37^{\circ} \mathrm{C}$ por $30 \mathrm{~min}$, adicionando-se, após esse período, $5 \mu \mathrm{L}$ de GTP a $10 \mathrm{mM}$, seguido da incubação por mais $30 \mathrm{~min}$. Em seguida foram acrescentadas $10 \mathrm{U}$ da enzima SP6 RNA Polimerase deixando a reação por mais $60 \mathrm{~min}$ a $37{ }^{\circ} \mathrm{C}$. Por fim, foi feita uma incubação de $20 \mathrm{~min}$ a $-20{ }^{\circ} \mathrm{C}$ para interromper a reação. Uma alíquota foi retirada para checar o RNA sintetizado, através da eletroforese em gel de agarose $1 \%$. O restante foi purificado com o kit RNeasy Mini kit (Qiagen), quantificado pelo NanoDrop ND-1000 a $260 \mathrm{~nm}$ e analisado em gel de agarose $1 \%$. 


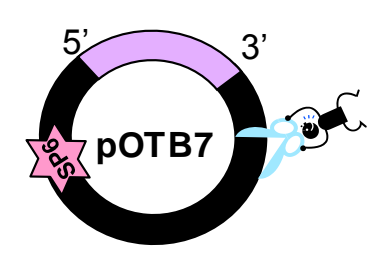

cDNA circular

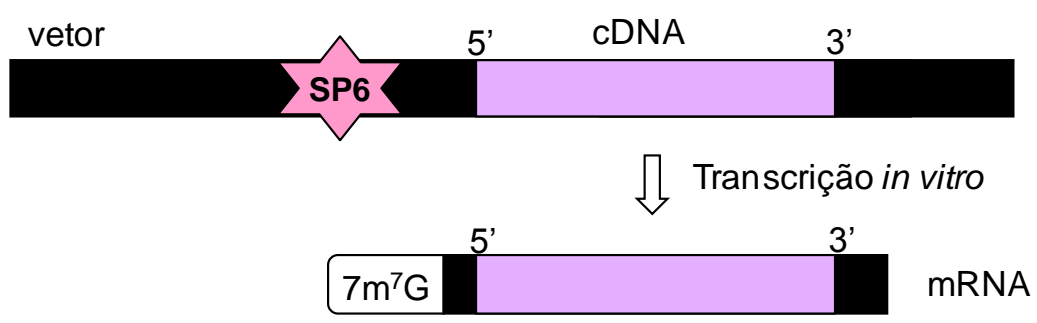

Figura 3 - Esquema simplificado das etapas fundamentais para realização da transcrição in vitro. A figura mostra um vetor hipotético (em preto) com um inserto clonado (em lilás), no sentido do promotor SP6, sendo clivado por uma enzima de restrição a 3' deste inserto. Com o vetor linearizado, é possível que a enzima SP6 polimerase reconheça o promotor SP6 e passe a sintetizar as fitas simples de RNA, através da adição das bases nucleotídicas (ATP, CTP, UTP e GTP) em condições ideais de reação. Sabendo-se que o CAP é um 7-metil-guanosina, este pode ser incorporado na reação de transcrição in vitro, como se fosse uma das bases nucleotídicas. Porém, para que o análogo do CAP seja adicionado à fita de mRNA, deve-se reduzir a concentração do GTP que compete com o CAP nas reações de transcrição in vitro. Assim, tem-se como produto final, teoricamente, um RNA mensageiro maduro, com o CAP e uma parte da cauda poliA, sintetizada a partir da cauda poli-T do cDNA ou inserida no vetor.

\subsection{Avaliação da viabilidade celular}

A viabilidade das células transfectadas, com DNA e mRNA, foi avaliada pela marcação das mesmas com anexina- $\mathrm{V}$ (Proteimax) e iodeto de propídeo (PI) (BD Pharmingen). A anexina é uma proteína com capacidade de se ligar fortemente à fosfatidilserina, exposta na camada externa da membrana em células apoptóticas. Já o PI é um corante que penetra as células mortas e se liga aos ácidos nucléicos. A morte celular por necrose se caracteriza pela presença de células anexina $\mathrm{PI}^{+}$; a morte por apoptose tardia, por células anexina ${ }^{+} \mathrm{PI}^{+}$; e células em apoptose inicial se marcam como anexina ${ }^{+} \mathrm{Pl}^{-}$. As células anexina $\mathrm{Pl}^{-}$são consideradas viáveis.

Após 48 horas da transfecção, as células foram removidas da placa de cultura, aliquotadas em tubos plásticos de $1,5 \mathrm{~mL}$, lavadas com $200 \mu \mathrm{L}$ tampão de ligação diluído 1X (BD Pharmingen) e ressuspendidas em uma mistura contendo anexina (Proteimax), na diluição 1:500, e $5 \mu \mathrm{L}$ de $\mathrm{PI}(50 \mu \mathrm{g} / \mathrm{mL})$, para um volume final de $100 \mu \mathrm{L}$ de tampão de ligação. As amostras foram incubadas por 20min à temperatura ambiente, no escuro. Após esse período, adicionaram-se mais $200 \mu \mathrm{L}$ de tampão de ligação em cada amostra e estas foram lidas imediatamente no citômetro de fluxo (FACSCanto II) com o software FACSDiva (BD Biosciences). Os 
dados obtidos foram analisados com o software FlowJo 8.7 (Tree Stars Inc.). A calibração do citômetro foi efetuda com base em células mortas, as quais foram expostas a $65^{\circ} \mathrm{C}$ por 15 minutos e células vivas, marcadas com anexina e/ou PI. Os gráficos desses controles podem ser observados na Figura 4.
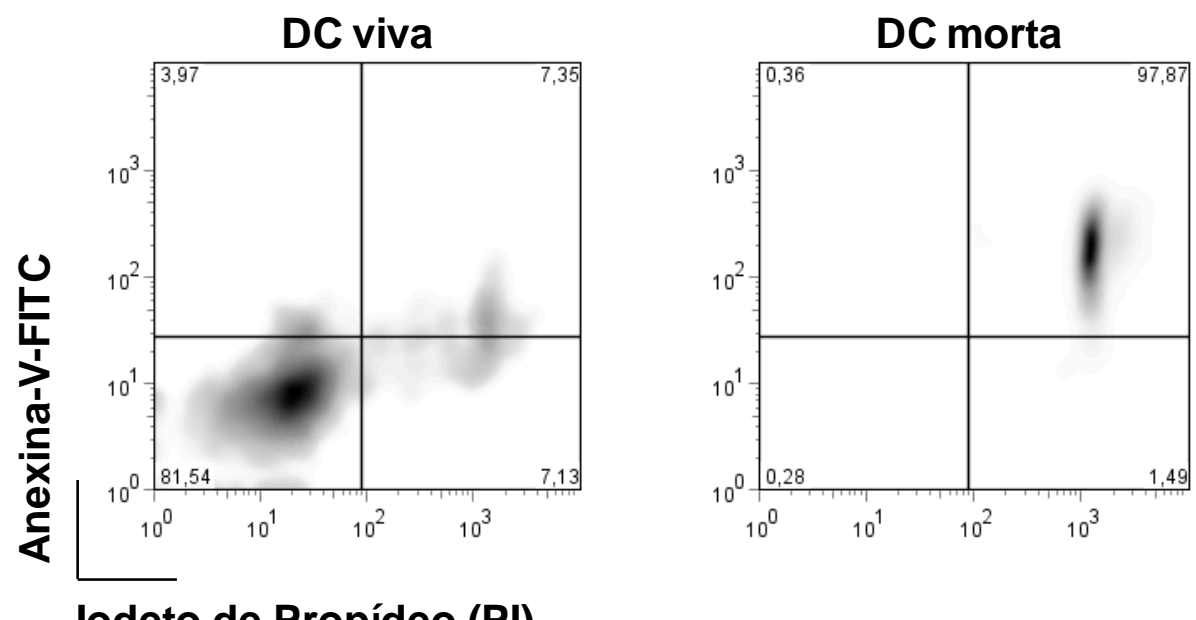

lodeto de Propídeo (PI)

Figura 4 - Gráficos ilustrando as células controles da marcação com anexina-V e PI. Gráficos dos controles da marcação com anexina- $\mathrm{V}$ e iodeto de propídeo $(\mathrm{PI})$ mostrando as $\mathrm{DCs}$ vivas com dupla marcação (à esquerda) e DCs mortas pelo calor, aquecidas a $65^{\circ} \mathrm{C}$ por $15 \mathrm{~min}$, com dupla marcação (à direita). As células $\mathrm{Pl}^{+}$anexina são consideradas necróticas, as células $\mathrm{Pl}^{-}$anexina ${ }^{+}$são consideradas em apoptose inicial, as células $\mathrm{Pl}^{+}$anexina ${ }^{+}$são consideradas em apoptose tardia e as células Pl'anexina são consideradas vivas. As análises foram feitas em gates de tamanho por granulosidade característicos das DCs.

\subsection{Avaliação da atividade aloestimuladora das DCs transfectadas com mRNA}

Para avaliar a capacidade aloestimuladora das células após a transfecção com mRNA da survivina, DCs foram co-cultivadas com linfócitos $T$ alogenêicos na proporção 1:30 em um volume final de $300 \mu \mathrm{L} /$ poço, em placa de 96 poços. As células foram mantidas por cinco dias em estufa com atmosfera contendo $5 \%$ de $\mathrm{CO}_{2}$ e saturada com água, a $37^{\circ} \mathrm{C}$, quando a resposta linfocitária foi avaliada. O isolamento dos linfócitos $\mathrm{T} \mathrm{CD}^{+}$foi obtido através da separação por seleção positiva em coluna imunomagnética com MACS MultiSort MicroBeads, de acordo com o protocolo recomendado pelo fabricante (Miltenyi Biotec).

Para avaliação da proliferação celular, os linfócitos $T$ foram incubados, antes da co-cultura com as DCs, em tampão PBS-BSA 0,1\%, contendo $5 \mu \mathrm{M}$ de CFSE 
(LYONS, 2000). A incubação foi feita a $37{ }^{\circ} \mathrm{C}$, no escuro, por $10 \mathrm{~min}$. Após este período, foram adicionados $5 \mathrm{~mL}$ de meio RPMl gelado, incubando-se as células no gelo, por mais 5 minutos. As células, então, foram lavadas 2 vezes em meio R-10. Os linfócitos marcados foram co-cultivados com DCs e ao término da cultura, as células foram retiradas, colocadas em tubos plásticos de $1,5 \mathrm{~mL}$ e centrifugadas a $17946 \mathrm{~g}$, a $4 \stackrel{\circ}{ } \mathrm{C}$ por $10 \mathrm{~s}$. O sobrenadante foi armazenado para dosagem de citocinas e as células foram submetidas à marcação com anticorpos monoclonais comerciais para CD4 e CD8, adquiridas no citômetro de fluxo (FACSCalibur BD, BD Biosciences) e analisadas pelo software FlowJo.

Os resultados foram representados pelos Índices de Estimulação (IE), calculados pelo coeficiente da Intensidade Mediana de Fluorescência (MFI) do CFSE dos linfócitos isolados (sem estímulo) pela MFI do CFSE de linfócitos mantidos em co-cultura com DCs. Ainda, foi calculado um IE relativo, para avaliar o IE obtido para os linfócitos em cultura com DCs transfectadas com relação ao IE obtido para os linfócitos em cultura com DCs controles (sem tratamento), ou seja, IE relativo indica a razão entre IE do grupo experimental e o IE do grupo controle.

\subsection{Detecção da produção de citocinas por ensaio imunoenzimático (ELISA)}

Para detecção das citocinas no sobrenadante da cultura de DCs (IL-12p70 e IL-10) e das co-culturas (IL-10 e IFN-gama) foram utilizados os kits BD OptEIA ${ }^{\mathrm{TM}}$ (BD, BD Biosciences). Neste método, placas de 96 poços Maxisorp (Nunc) foram sensibilizadas com $50 \mu \mathrm{L} /$ poço do anticorpo (Ac) de captura para cada citocina, diluído em tampão $\mathrm{NaCO}_{3}(\mathrm{pH} 9,5)$ e mantidas a $4{ }^{\circ} \mathrm{C}$ overnight. Após 3 lavagens com $200 \mu \mathrm{L} /$ poço de tampão de lavagem (PBS contendo 0,05\% de Tween 20, pH 7,2 ), as placas foram bloqueadas com $200 \mu \mathrm{L} /$ poço de tampão de bloqueio (PBS com $10 \%$ de soro fetal bovino) por 1 hora à temperatura ambiente. Em seguida, após 3 lavagens, as amostras e a curva-padrão foram incubadas por um período de 2 horas à temperatura ambiente. Para a curva-padrão, as citocinas recombinantes foram incubadas em duplicatas de $45 \mu \mathrm{L}$ por poço das diluições seriadas (fator 2 de diluição), conforme recomendações do fabricante. Após 5 lavagens, foram adicionados $50 \mu \mathrm{L} /$ poço de Ac de detecção diluído em tampão de bloqueio, juntamente com estreptoavidina, seguindo-se uma nova incubação por 1 hora, à temperatura ambiente, no escuro. 
Após esse período a placa foi lavada 7 vezes e adicionaram-se $50 \mu \mathrm{L}$ / poço de substrato $\left(\mathrm{H}_{2} \mathrm{O}_{2}\right.$ e tetrametilbenzidina, $\mathrm{BD}$ Biosciences $)$, com incubação de 30 min, no escuro, à temperatura ambiente. Por fim, $50 \mu \mathrm{L}$ / poço de $\mathrm{H}_{2} \mathrm{SO}_{4}(2 \mathrm{~N})$ foram adicionados para interromper a reação e a densidade óptica foi determinada em espectrofotômetro com filtro de $450 \mathrm{~nm}$. O cálculo das concentrações foi feito com auxílio do software Softmax Pro, através da equação de regressão linear com base na curva padrão e a análise de dados foi executada com auxílio do software Prisma.

\subsection{Obtenção das células leucêmicas}

O sangue periférico dos pacientes portadores de LLC, não submetidos a nenhum um tipo de tratamento, foi coletado em tubo com heparina por venóclise. Para obtenção das PBMCs, $10 \mathrm{~mL}$ de sangue foram processados para separação por gradiente de densidade em centrifugação com Ficoll-Paque Plus (GE Healthcare), conforme descrito no item 3.2. As células mononucleares obtidas foram utilizadas para isolamento dos linfócitos $B$ leucêmicos $\left(C D 19^{+} C D 5^{+}\right)$, através da separação por seleção positiva em coluna imunomagnética com MACS MultiSort MicroBeads (Miltenyi Biotec). Em um primeiro momento, as células foram lavadas com tampão PBS acrescido de $0,5 \%$ de soro albumina bovina (BSA) e $2 \mathrm{mM}$ de EDTA $(\mathrm{pH} 7,2)$ e ressuspendidas em $80 \mu \mathrm{L}$ do mesmo tampão para cada $10^{7}$ células. Para isolar os linfócitos $B\left(C D 19^{+}\right)$foram adicionados $20 \mu \mathrm{L}$ do anticorpo antiCD19 conjugado com esferas magnéticas e incubados a $4^{\circ} \mathrm{C}$ por $30 \mathrm{~min}$. As células foram lavadas, ressuspendidas em $3 \mathrm{~mL}$ de tampão e introduzidas em coluna de afinidade (tipo LS) acoplada ao separador VarioMACS (Miltenyi Biotec), para passagem das células não marcadas ( $1^{\circ}$ seleção negativa), coletadas em tubos de $15 \mathrm{~mL}$. Após isto, retirou-se a coluna do separador, para remoção das células marcadas que ficaram aderidas por força eletromagnética (seleção positiva), colocando-se $5 \mathrm{~mL}$ de tampão e pressionando o êmbolo fornecido. Este procedimento foi repetido 2 vezes, gerando um volume final de $10 \mathrm{~mL}$, do qual uma alíquota foi separada para marcação das células para citometria de fluxo. O próximo passo foi remover enzimaticamente as esferas magnéticas das células CD19+, incubando-as com $20 \mu \mathrm{L} / \mathrm{mL}$ do reagente de liberação (Miltenyi Biotec) a $4{ }^{\circ} \mathrm{C}$ por $15 \mathrm{~min}$. As células foram lavadas e ressuspendidas em $50 \mu \mathrm{L}$ de tampão acrescido de $30 \mu \mathrm{L}$ do reagente de parada, incubando-se por $15 \mathrm{~min}$. Após uma lavagem, as 
células foram passadas em coluna MS para purificar a amostra. Procedeu-se a marcação, com $2 \mu \mathrm{L}$ por $2 \times 10^{5}$ células, do anticorpo anti-CD5 conjugado com FITC, incubando-se por $20 \mathrm{~min}$ a $4{ }^{\circ} \mathrm{C}$. Depois de 2 lavagens, foram adicionados $10 \mu \mathrm{L}$ do anticorpo anti-FITC conjugado às esferas magnéticas às células ressuspendidas em $90 \mu \mathrm{L}$ de tampão, incubando a $4{ }^{\circ} \mathrm{C}$ por $15 \mathrm{~min}$. Após este período, as células foram passadas novamente através das colunas de afinidade MS, para obtenção dos linfócitos $\mathrm{B} \mathrm{CD} 19^{+} \mathrm{CD}^{+}$através de uma seleção positiva. Uma alíquota das células foi separada para marcação das moléculas de superfície, e posterior análise por citometria de fluxo. O restante foi utilizado para extração do RNA total e subseqüente amplificação dos antígenos tumorais de interesse.

\subsection{Extração de RNA total das células leucêmicas}

Cerca de 5-10 $\times 10^{6}$ células tumorais de paciente com LLC tiveram seu RNA extraído com adição de $1 \mathrm{~mL}$ de Trizol $^{\circledR}$ (Invitrogen) e ressuspensão vigorosa com auxílio de pipeta. As amostras foram incubadas por $5 \mathrm{~min}$, à temperatura ambiente, para a completa dissociação dos complexos nucleoprotéicos. Adicionou-se $0,2 \mathrm{~mL}$ de clorofórmio e os tubos fechados contendo as amostras foram agitados manualmente de forma vigorosa por $15 \mathrm{~s}$. Estas foram então incubadas de 2 a $3 \mathrm{~min}$ à temperatura ambiente. Após esse período, as amostras foram centrifugadas a 12000 g por 15 minutos a $4 \stackrel{\circ}{C}$. A fase aquosa incolor superior, contendo o RNA, foi retirada e transferida para outro tubo. O RNA foi então precipitado adicionando-se $0,5 \mathrm{~mL}$ de álcool isopropílico e incubado por $10 \mathrm{~min}$ à temperatura ambiente. $\mathrm{Em}$ seguida, as amostras foram centrifugadas a $12000 \mathrm{~g}$ por $10 \mathrm{~min}$ a $4{ }^{\circ} \mathrm{C}$. $\mathrm{O}$ sobrenadante foi removido e o sedimento lavado com $1 \mathrm{~mL}$ de etanol a $75 \%$ em água DEPC. Após leve agitação, as amostras foram centrifugadas a $7500 \mathrm{~g}$ por 5 min a $4 \stackrel{\circ}{\circ}$, o sobrenadante foi removido e o sedimento seco à temperatura ambiente por alguns minutos. Por fim, o RNA foi dissolvido em água DEPC para um volume de $20 \mu \mathrm{L}$. Em seguida, foi armazenado a $-80 \stackrel{\circ}{ } \mathrm{C}$ para posterior quantificação pelo espectrofotômetro NanoDrop ND-1000 a 260 nm. A integridade do RNA extraído foi avaliada pela visualização de duas bandas fortes, correspondentes aos RNAs das subunidades ribossomais $18 \mathrm{~S}$ e $28 \mathrm{~S}$, após eletroforese em gel de agarose $1 \%$ corado com GelRed ${ }^{\mathrm{TM}}$ Nucleic Acid Gel Stain (Biotium). 


\subsection{Transcrição reversa (RT-PCR) e amplificação do mRNA tumotal total (PCR)}

As reações de transcrição reversa e de amplificação do mRNA total foram adaptadas de Boczkowski (2000).

Para obtenção da primeira fita do cDNA, 300 ng do RNA total foi submetida à transcrição reversa, num volume final de $20 \mu \mathrm{l}$, com $10 \mathrm{pmol}$ do primer modificado de oligo-dT [5'-AAGCAGTGGTATCAACGCAGAGTACT(30)VN-3'], onde $V(G, A$ ou C) e N (G, T, A ou C) (IDT - Integrated DNA technologies - Coralville, IA, USA), e $4 \mu \mathrm{L}$ de dNTPs a $2,5 \mathrm{mM}$ (Invitrogen). Após incubação da reação a $70^{\circ} \mathrm{C}$ por $15 \mathrm{~min}$, esta foi refrigerada a $4{ }^{\circ} \mathrm{C}$ por $5 \mathrm{~min}$, quando foi adicionado uma mistura contendo 200 unidades da enzima de transcrição reversa SuperScript III (Invitrogen) com $4 \mu \mathrm{L}$ do seu tampão 5x,1 $1 \mu \mathrm{L}$ de DTT 0,1M (Invitrogen), e 40 unidades de RNAse OUT (Invitrogen). A reação foi mantida a $25{ }^{\circ} \mathrm{C}$ por $5 \mathrm{~min}$, e depois por mais 1 hora a 42 ${ }^{\circ} \mathrm{C}$. Após essa primeira hora de transcrição reversa foram adicionados $10 \mathrm{pmol}$ do primer T7 modificado (5'-CTAATACGACTCACTATAGGGCGGG-3') (IDT) e a reação foi mantida mais 1 hora a $42{ }^{\circ} \mathrm{C}$ para obtenção da fita complementar. A inativação da reação foi feita a $70^{\circ} \mathrm{C}$ por 15 minutos.

O cDNA foi amplificado pela adição de $2 \mu$ l do produto da reação de transcrição reversa em $50 \mu \mathrm{l}$ de volume final da reação de PCR contendo $20 \mathrm{pmol}$ dos seguintes primers: T7 PCR (5'-CCATCCTAATACGACTCACTATAGGGC-3') (IDT) e 3' PCR (5'- AAGCAGTGGTATCAACGCAGAGT-3') (IDT). As condições de amplificação foram adaptadas para a enzima Taq High Fidelity DNA polymerase (Invitrogen) com adição de 2,5 unidades da enzima com $5 \mu \mathrm{L}$ do seu tampão 10x, 4 $\mu \mathrm{L}$ de dNTPs a 2,5 mM (Invitrogen) e $2 \mu \mathrm{L}$ de $\mathrm{MgCl}_{2}$ para uma concentração final de $2 \mathrm{mM}$. A condição do ciclo foi a seguinte: 2 min de desnaturação inicial a $94{ }^{\circ} \mathrm{C}$, seguido de 35 ciclos de $94{ }^{\circ} \mathrm{C}$ por 30 s para desnaturação, $60{ }^{\circ} \mathrm{C}$ por 30 s para anelamento, e $68^{\circ} \mathrm{C}$ por $3 \mathrm{~min}$ para extensão. A quantificação do material obtido foi feita pelo espectrofotômetro NanoDrop ND-1000 a $260 \mathrm{~nm}$. O cDNA obtido desta reação de amplificação foi usado para posterior transcrição in vitro. 


\subsection{Transcrição in vitro do cDNA total amplificado}

Para reação de transcrição in vitro foi usado $1 \mu \mathrm{g}$ do produto de amplificação do cDNA total. Foi preparada uma mistura de nucleotídeos (NTPs) composta por ATP, CTP e UTP a $10 \mathrm{mM}$ e GTP a $1 \mathrm{mM}$. Desta mistura utilizou-se $10 \mu \mathrm{L}$ para uma concentração final de $2 \mathrm{mM}$ de NTPs (Invitrogen), 2,5 $\mu \mathrm{L}$ da estrutura análoga do Cap a 10 mM (7mG(ppp)G RNA Cap Structure Analog, New England BioLabs), DTT (Invitrogen) para uma concentração final de $5 \mathrm{mM}, 50 \mathrm{U}$ do Inibidor de RNAse (40.000U/mL, New England BioLabs), $30 \mathrm{U}$ da enzima T7 RNA Polimerase (50U/ $\mu \mathrm{L}$, Invitrogen) com seu tampão na concentração final 1x, completando-se o volume da reação para $50 \mu \mathrm{L}$ com água tratada com DEPC. A reação foi incubada a uma temperatura de $37^{\circ} \mathrm{C}$ por $30 \mathrm{~min}$, adicionando-se, após esse período, $5 \mu \mathrm{L}$ de GTP a $10 \mathrm{mM}$, seguido da incubação por mais $30 \mathrm{~min}$. Em seguida foi acrescentado $10 \mathrm{U}$ da enzima T7 RNA Polimerase deixando a reação por mais 60 min a $37^{\circ} \mathrm{C}$. Por fim, foi feita uma incubação de 20 min a $-20^{\circ} \mathrm{C}$ para interromper a reação. Parte do RNA foi tratada com RQ1 RNAse-free DNAse (Promega) de acordo com as instruções do fabriacante. A quantificação foi feita pelo NanoDrop ND-1000 a $260 \mathrm{~nm}$.

\subsection{PCR quantitativa em tempo real (qPCR)}

Para avaliar a expressão do mRNA dos antígenos tumorais survivina e RPSA pelas células leucêmicas, e verificar se a expressão destes se mantém após a amplificação do mRNA total e reações de transcrição in vitro utilizou-se a técnica de PCR em tempo real com o kit SYBR ${ }^{\circledR}$ Green PCR Master Mix (Applied Biosystems). Para tanto, as amostras de RNA extraído das células leucêmicas foram submetidas à transcrição reversa para obtenção do cDNA, conforme descrito no item 3.17 , que por sua vez foi amplificado (item 3.17) e submetido a transcrição in vitro, para finalmente gerar mRNAs dos genes expressos no momento da extração. Como não é possível verificar a funcionalidade da técnica de transcrição in vitro através da corrida do mRNA total sintetizado em gel de agarose, já que não seria visualizada uma banda única referente a um antígeno específico, resolveu-se sintetizar fitas de cDNA, a partir deste mRNA transcrito, e novamente amplificá-lo. Do primeiro e segundo produtos de PCR obtidos, foi verificada a expressão dos antígenos survivina e RPSA, por qPCR. 
Cada reação $(12,5 \mu \mathrm{L})$ foi composta por $6,25 \mu \mathrm{L}$ de SYBR, 4,25 $\mu \mathrm{L}$ de água ultrapura autoclavada, $0,375 \mu \mathrm{L}$ de cada iniciador $(10 \mathrm{pmol} / \mu \mathrm{L})$ e $1 \mu \mathrm{L}$ de cDNA. As condições para a reação foram: $95 \stackrel{\circ}{\mathrm{C}}$ por 10 minutos para a ativação da enzima AmpliTaq Gold DNA Polimerase presente no SYBR mix, 40 ciclos de desnaturação a $95{ }^{\circ} \mathrm{C}$ por 15 segundos e anelamento e extensão a $60{ }^{\circ} \mathrm{C}$ por 1 minuto, seguido da curva de dissociação (95 ${ }^{\circ} \mathrm{C}$ por 1 minuto, $60 \stackrel{\circ}{\mathrm{C}}$ por 30 segundos e $95{ }^{\circ} \mathrm{C}$ por 30 segundos). A reação de qPCR foi realizada no equipamento Stratagene $\mathrm{Mx3000P}$ QPCR System e aquisição dos resultados pelo software MxPro ${ }^{\mathrm{TM}}$ 3.0. Pares de oligonucleotídeos iniciadores exônicos, para os genes Survivina, RPSA e $\beta$-actina, foram desenhados com base em seqüências de referência depositadas no NCBI (http://www.ncbi.nlm.nih.gov) com o auxílio do software PRIMER 3 (frodo.wi.mit.edu) (Tabela 5). Figuras representativas das curvas de amplificação e de dissociação padronizadas para os primers desenhados podem ser observadas na Figura 5.

Tabela 5 - Seqüências dos primers utilizados nas reações de PCR em tempo real. Seqüências dos primers foward $(F)$ e reverse $(R)$ para survivina, RPSA e $\beta$-actina, e números de identificação das seqüências de cDNA presentes no banco de dados do NCBI utilizadas para o desenho desses.

\begin{tabular}{ccc}
\hline \hline Gene & Seqüências dos primers & \#NCBI \\
\hline \multirow{2}{*}{ Survivina } & F5'- CCCATAGAGGAACATAAAAAGCATTC -3' & NM_000017.9 \\
& R5'- TCAAAAATTCACCAAGGGTTAATTCT -3' & \\
RPSA & F5'- GGTGGCACCAATCTTGACTT -3' & NM_000003.11 \\
& R5'- ATCAGCAGGGTTTTCAATGG -3' & \\
ß-actina & F5'- ACGAAACTACCTTCAACTCCATCAT -3' & NM_001101.3 \\
& R5'- ATGATCTTGATCTTCATTGTGCTG-3' & \\
\hline \hline
\end{tabular}




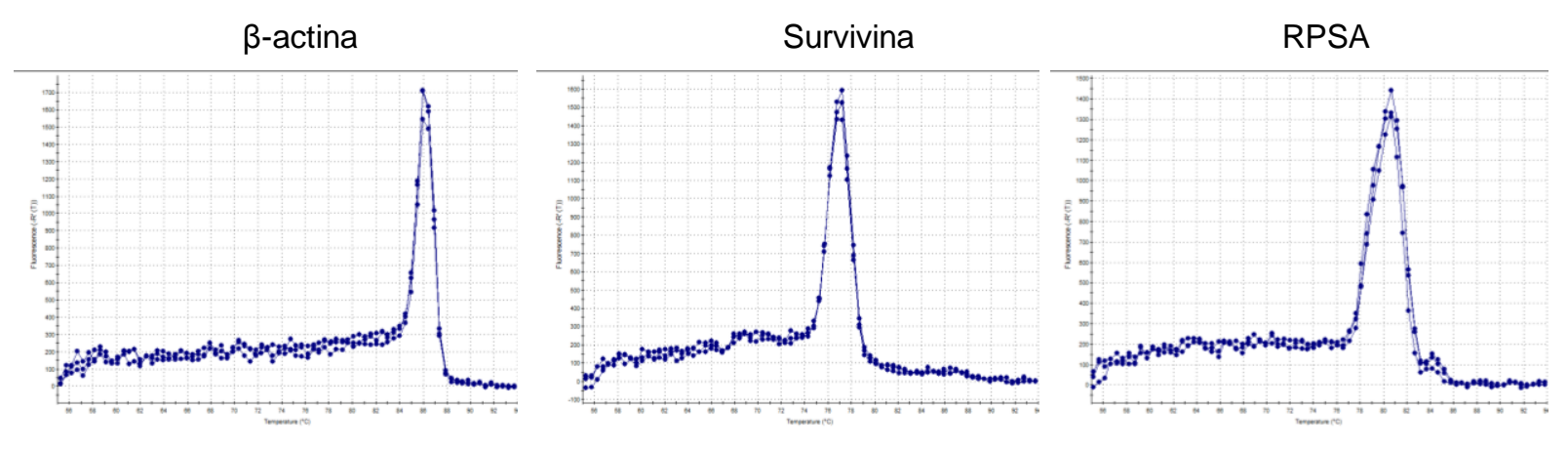

Figura 5 - Curvas de dissociação dos primers para os genes $\beta$-actina, survivina e RPSA. Curvas de dissociação obtidas por PCR em tempo real, a partir de RNA extraído das células tumorais. A presença de um pico único de dissociação corresponde à amplificação de um produto especifico. (A) Curva de dissociação da $\beta$-actina. (B) Curva de dissociação da survivina. (C) Curva de dissociação da RPSA.

A expressão relativa dos genes alvos foi analisada pelo método do $2^{-\triangle \Delta C T}$ descrito por Livak e Schimittgen (2001). Segundo este método, subtrai-se o $\mathrm{Ct}$ (Threshold cicle) da amostra de interesse pelo $\mathrm{Ct}$ do gene constitutivo dessa mesma amostra, no caso, $\beta$-actina, dando origem ao valor $\Delta \mathrm{Ct}$. Em seguida, calcula-se o $\Delta \Delta \mathrm{Ct}$, que trata da diferença entre o valor de $\Delta \mathrm{Ct}$ de uma amostra em questão e o $\Delta \mathrm{Ct}$ de uma amostra calibradora, a partir da qual todas as amostras farão referência. Neste trabalho, utilizaram-se os valores de $\triangle \mathrm{Ct}$ do produto da primeira PCR, feita para amplificação do cDNA total, como amostra calibradora. Por fim, calcula-se o valor de $2^{-\Delta \Delta C t}$, obtendo-se, assim, a expressão relativa de determinado gene de interesse. Este método parte do princípio de que a eficiência da reação de amplificação do gene alvo deve ser igual à do gene constitutivo, ambas próximas de $100 \%$. Testaram-se as eficiências de amplificação dos diferentes genes, e após constatação de eficiências acima de $90 \%$, foi possível eleger esse método de análise.

\subsection{Análises estatísticas}

Os dados obtidos quanto à fenotipagem de monócitos, iDCs e mDCs foram, inicialmente, analisados quanto à homogeneidade da variância, utilizando-se o Teste de Bartlett. Após este teste, as amostras foram avaliadas pelo teste de análise da variância (ANOVA), seguida pelo teste de comparações múltiplas de Tukey-Kramer. As células cultivadas nos meios R10 e AIM-V foram comparadas pelo teste $T$ de 
Student. Em todas as análises, considerou-se significante o valor de $p<0,05$. As análises estatísticas dos resultados foram auxiliadas pelo software GraphPad Prisma (GraphPad Software Inc. - La Jolla, CA, USA). 
4 RESULTADOS 


\subsection{Caracterização morfológica e fenotípica de monócitos, DCs imaturas e maduras}

Para verificar as alterações morfológicas e fenotípicas induzidas pela cultura de geração de DCs a partir de monócitos do sangue periférico, avaliou-se a aparência das células em cultura, observadas ao microscópio de luz, e a presença das moléculas de superfície nas células obtidas nos dias zero, cinco e sete da cultura, usando os marcadores HLA-DR, CD14, CD80, CD86, CD40, CD83, CD11c e CD1a, através da citometria de fluxo. A diferenciação em DCs foi realizada nos meios de cultura AIM-V e RPMI-1640 suplementado com 10\% de soro fetal bovino (R-10), pois a padronização da metodologia de transfecção foi feita em DCs cultivadas em ambos os meios.

De maneira geral, no dia zero da cultura foram observadas, à microscopia de luz, pequenas células arredondadas aderidas ao plástico, que são consideradas monócitos (Figura 6A). No quinto dia da cultura, mediante ao tratamento com as citocinas IL-4 e GM-CSF, as células, agora consideradas DCs imaturas, apresentaram-se mais alongadas, aparentando maior superfície celular (Figura 6B). Já no sétimo dia da cultura, as $\mathrm{DC}$, que já foram ativadas com coquetel de citocinas, amadurecem e encontram-se soltas na cultura com um aspecto oval e pequenas projeções de membrana (Figura 6C).

$\mathbf{A}$

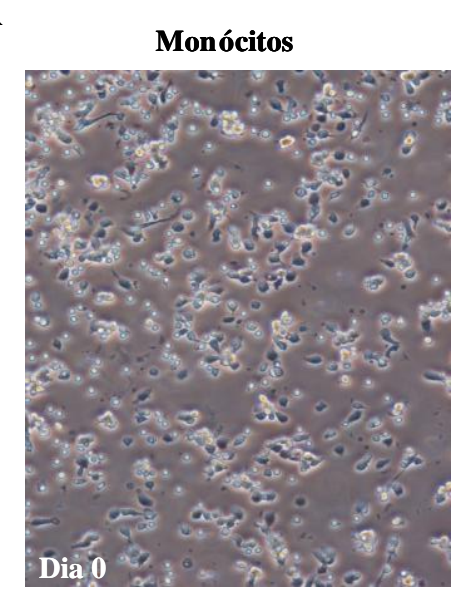

B

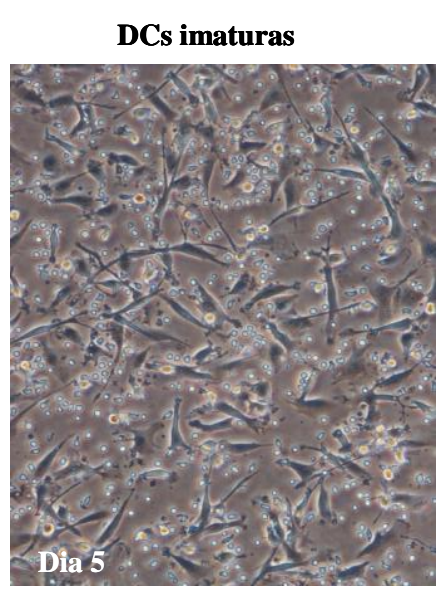

$\mathbf{C}$

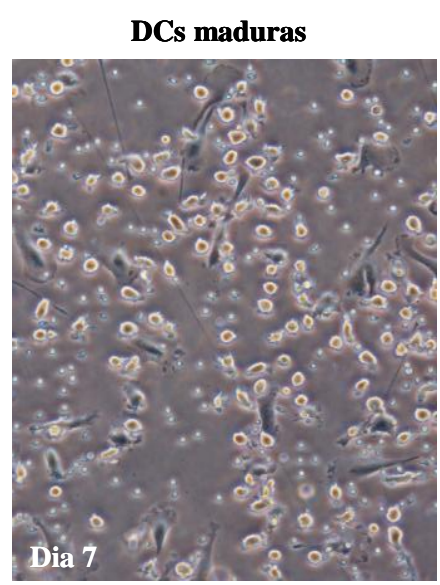

Figura 6 - Fotomicrografias do aspecto morfológico da cultura de diferenciação em DCs. (A) Células aderentes ao plástico, obtidas a partir de PBMCs separadas por gradiente de ficoll, no dia zero da cultura, correspondentes aos monócitos. (B) Células alongadas, obtidas após o tratamento com IL-4 e GM-CSF, no quinto dia da cultura, correspondente às DCs imaturas. (C) Células não-aderentes ovais com projeções de membrana, obtidas após adição de TNF-a, IL-1 $\beta$, IL-6 e PGE2, no sétimo dia da cultura, correspondente às DCs maduras. Aumento de 200x. 
$\mathrm{Na}$ análise morfológica, a freqüência de células grandes e granulosas, características de DCs, analisadas no gate de FSC e SSC, apresentou-se mais elevada quando a cultura foi realizada no meio R10 ( $p=0,0106)$ (Figura 7). Já para DCs imaturas não houve diferença significativa.
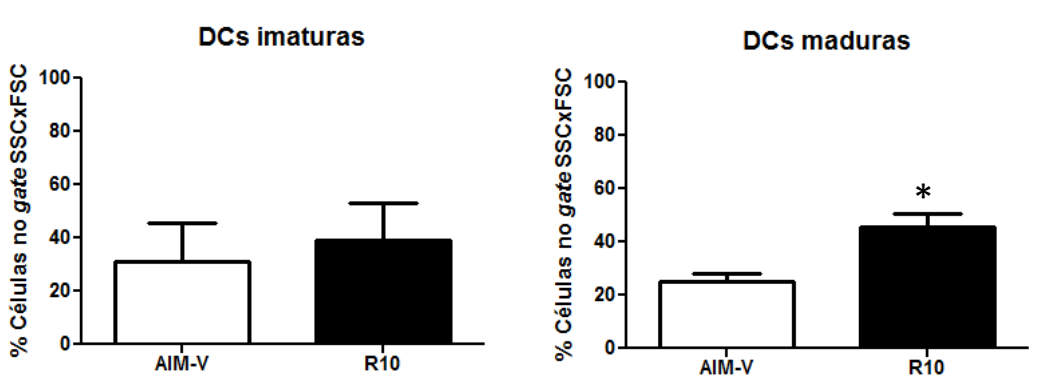

Figura 7 - Freqüência de células no gate de tamanho (FSC) por granulosidade (SSC) característicos de DCs, nos meios de cultura AIM-V e R10. As análises estatísticas foram realizadas pelo teste t não-pareado; ${ }^{*} p=0,0106$.

Na análise fenotípica, observou-se que durante os estágios de diferenciação e maturação em DCs há diminuição significativa na freqüência de células CD14+, marcadoras de monócitos e macrófagos, tanto no meio de cultura AIM-V (monócitos $76,9_{ \pm} 9,0 \%$, iDCs $19,4 \pm 14,3 \%$ e mDCs $\left.8,6 \pm 5,1 \%, \quad p=0,0001\right)$ quanto no $R 10$ (monócitos $72,2 \pm 6,0 \%$, iDCs $10,5 \pm 8,7 \%$ e mDCs $9,7 \pm 12,2 \%, p<0,0001$ ). Para HLADR, molécula de MHC de classe II, foi observada alta freqüência de células positivas

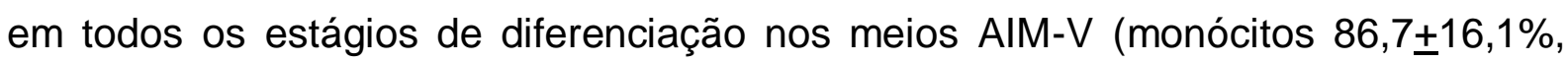
iDCs $89,3 \pm 10,2 \%$ e mDCs $88,1 \pm 11,8 \%$ ) e R10 (monócitos $78,9 \pm 26,8 \%$, iDCs $89,6 \pm 9,7 \%$ e mDCs $91,7 \pm 10,9 \%)$. Por ser uma molécula constitutiva, a freqüência de células positivas para CD86, mostrou-se elevada desde o dia zero da cultura no AIM-V (monócitos $87,4 \pm 17,0 \%$, iDCs $67,2 \pm 29,3 \%$ e mDCs $88,5 \pm 18,3 \%$ ) e no $\mathrm{R} 10$ (monócitos $89,4 \pm 18,4 \%$, iDCs $71,9 \pm 30,1 \%$ e mDCs $84,7 \pm 16,7 \%$ ). Já para as outras moléculas co-estimuladoras, observou-se um aumento significativo de células CD80+, no AIM-V (monócitos $17,3 \pm 20,2 \%$, iDCs $54,4 \pm 23,1 \%$ e mDCs $54,1 \pm 26,4 \%$, $\mathrm{p}=0,0133$ ) e no R10 (monócitos 18,6 $\pm 20,5 \%$, iDCs 46,6 $\pm 24,3 \%$ e mDCs $72,3 \pm 12,5 \%, p=0,0005)$, e pouca variação na porcentagem de células $C D 40^{+}$, no AIM-V (monócitos $19,9 \pm 28,5 \%$, iDCs $21,5 \pm 30,8 \%$ e mDCs $21,8 \pm 38,2 \%$ ) e no $\mathrm{R} 10$ (monócitos 10,8 $\pm 21,3 \%$, iDCs $14,4 \pm 24,9 \%$ e mDCs $13,2 \pm 17,9 \%$ ). Houve uma 
tendência ao aumento da freqüência de células $\mathrm{CD}_{83} 3^{+}$, presentes em condições de ativação, no AIM-V (monócitos $51,0 \pm 43,0 \%$, iDCs $52,4 \pm 32,5 \%$ e mDCs $76,1 \pm 16,5 \%$ ) e no R10 (monócitos $61,9 \pm 29,0 \%$, iDCs $65,4 \pm 28,7 \%$ e mDCs $73,0 \pm 33,3 \%$ ). Em

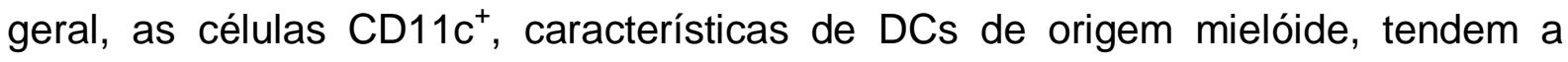
permanecer freqüentes desde o dia zero, tanto no AIM-V (monócitos $87,8 \pm 21,3 \%$, iDCs $85,2 \pm 7,9 \%$ e mDCs $82,6 \pm 10,9 \%$ ) quanto no R10 (monócitos $94,2 \pm 3,8 \%$, iDCs $89,2 \pm 20,7 \%$ e mDCs $86,4 \pm 14,7 \%$ ), enquanto as células CD123, consideradas características de DCs linfóides, foram significativamente menos freqüentes conforme as células vão se diferenciando e maturando, no AIM-V (monócitos $78,0 \pm 17,5 \%$, iDCs $37,6 \pm 33,6 \%$ e mDCs $38,2 \pm 32,3 \%, p=0,0287$ ) e também no R10 (monócitos $78,4 \pm 19,8 \%$, iDCs $28,6 \pm 25,8 \%$ e mDCs $30,7 \pm 29,5 \%, p=0,0091$ ). A porcentagem de células $\mathrm{CD} 1 \mathrm{a}^{+}$, molécula apresentadora de lipídeos e glicolipídeos, vai aumentando durante os estágios de diferenciação quando a cultura é realizada no meio R10 (monócitos $3,2 \pm 3,6 \%$, iDCs $54,5 \pm 25,5 \%$ e mDCs $48,7 \pm 28,0 \%$ ), o qual contém grande quantidade de lipídeos devido a presença do soro fetal bovino, e sua freqüência é mantida quando a cultura é feita no AIM-V $(3,7 \pm 4,8 \%$, iDCs $10,4 \pm 14,7 \%$ e mDCs $5,5 \pm 8,8 \%$ ) (Figuras 8 e 9). 

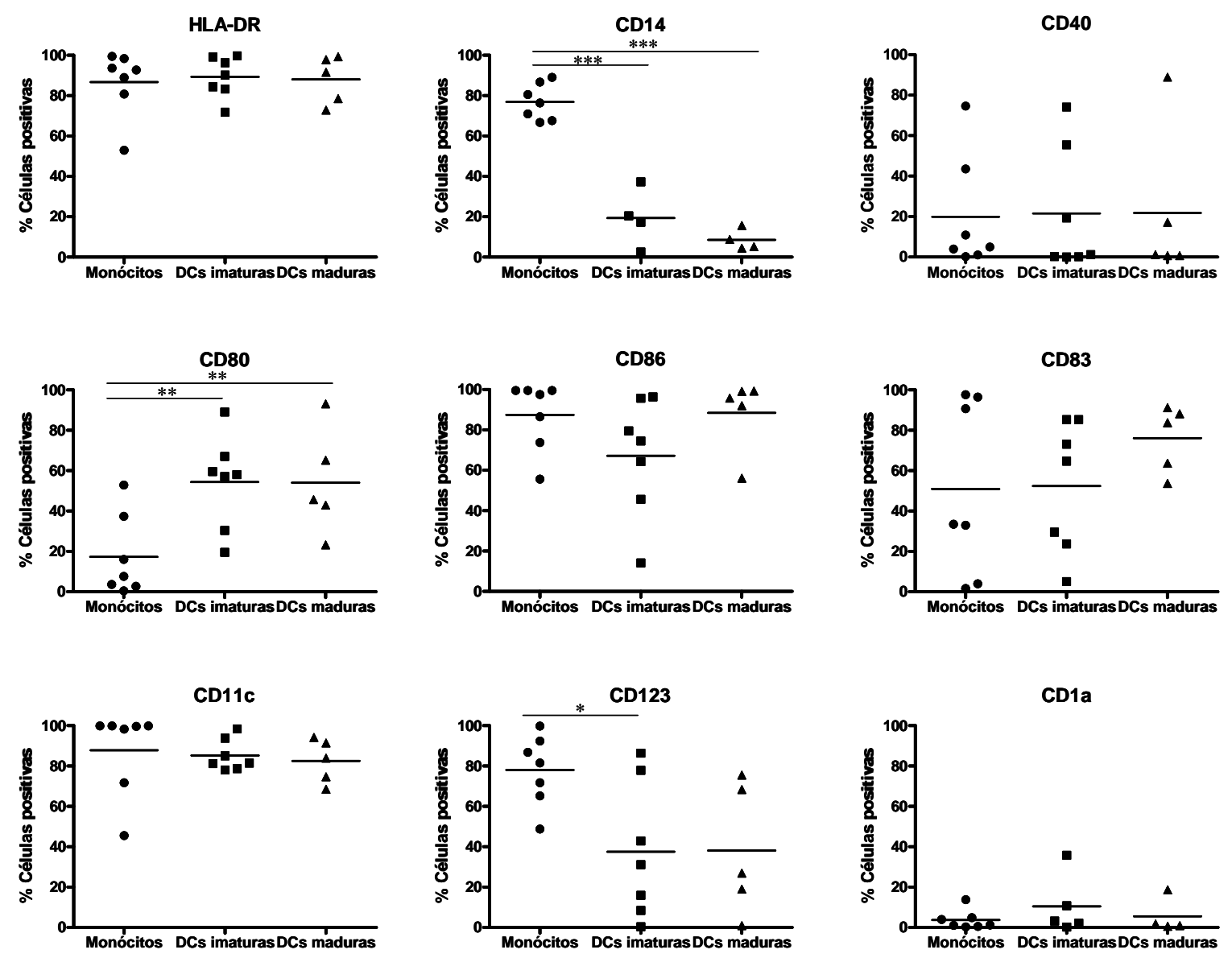

Figura 8 - Freqüência de células expressando os marcadores HLA-DR, CD14, CD80, CD86, CD40, CD83, CD11c, CD123 e CD1a, em monócitos iDCs e mDCs cultivadas no meio AIM-V. As análises foram feitas englobando as células que no gate SSCXFSC eram CD14 e HLA-DR ${ }^{+}$. Para as análises estatísticas foi utilizado ANOVA seguido do teste de comparações múltiplas de Tukey-Kramer; ${ }^{* * *} p<0,001 ;{ }^{* *} p=0,0133 ;{ }^{*} p=0,0287$. 

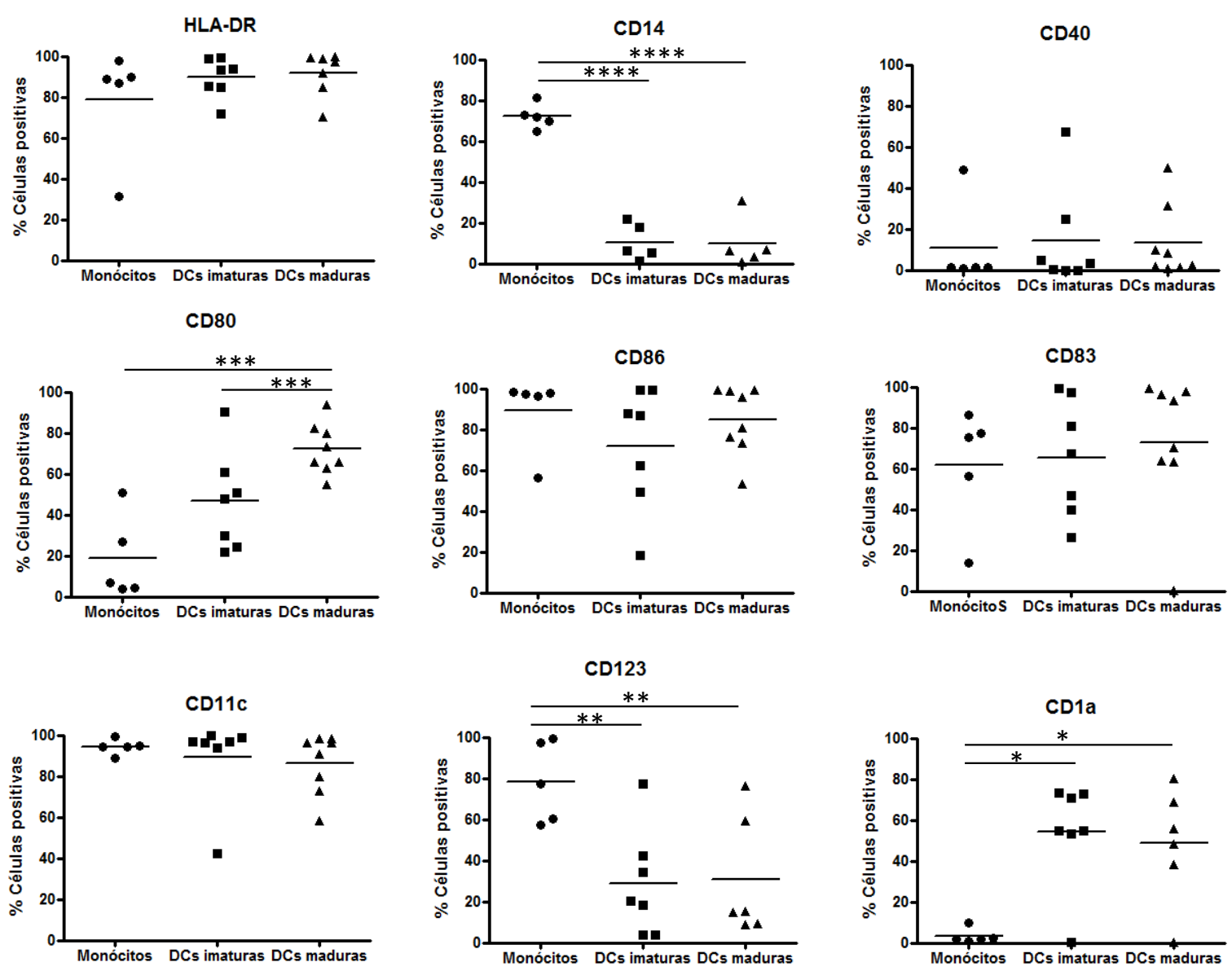

Figura 9 - Freqüência de células expressando os marcadores HLA-DR, CD14, CD80, CD86, CD40, CD83, CD11c, CD123 e CD1a, em monócitos iDCs e mDCs cultivadas no meio R10. As análises foram feitas englobando as células que no gate SSCxFSC eram CD14 e HLA-DR ${ }^{+}$. Para as análises estatísticas foi utilizado ANOVA seguido do teste de comparações múltiplas de Tukey-Kramer; ${ }^{* \star *} p<0,0001 ;{ }^{* \star *} p=0,0005 ;{ }^{* *} p=0,0091$; ${ }^{*} p=0,0038$. 


\subsection{Transfecção das DCs com vetor plasmideal pLV-EGFP}

Visto que existem vários métodos de transferência gênica, para padronização inicial dos experimentos foram testadas diferentes metodologias, tais como eletroporação e lipofecção, numa tentativa de determinar a mais eficaz para dar continuidade ao estudo. Em experimentos prévios, otimizou-se a transfecção nas DCs através do emprego de um vetor plasmideal ( $p L V$ ) contendo o gene que codifica a proteína fluorescente EGFP. Esta estratégia foi adotada por facilitar a identificação das células transfectadas, observando-se a fluorescência da proteína EGFP através da citometria de fluxo ou em microscópio de fluorescência.

A princípio, foi avaliada a funcionalidade da construção do vetor plasmideal pLV-EGFP transfectando-na na linhagem 293T, já que esta possui alta eficiência de transfecção. Neste caso foi utilizado a lipofecção das células com o agente de transfecção lipofectamina 2000. Após 24 e 48 horas, os resultados obtidos mostraram que este vetor plasmideal foi funcional, pois expressou eficientemente a proteína EGFP, observando-se que cerca de $50 \%$ das células foram transfectadas (Figuras 10). 
A

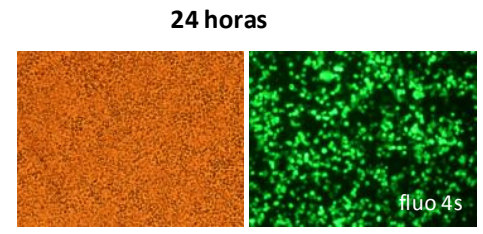

C

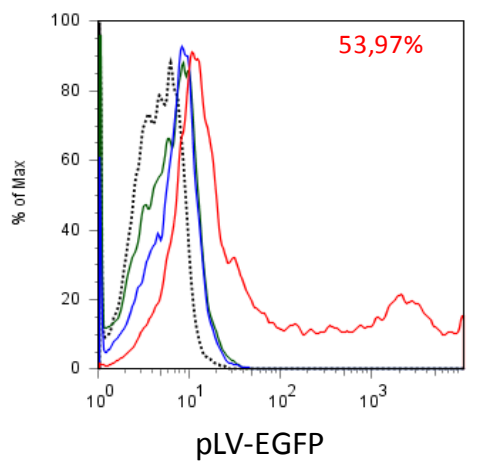

B

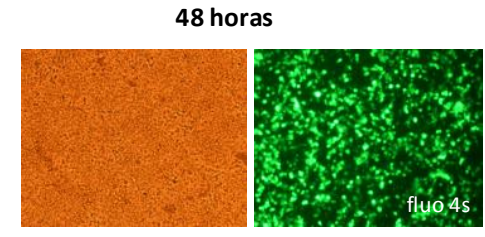

D

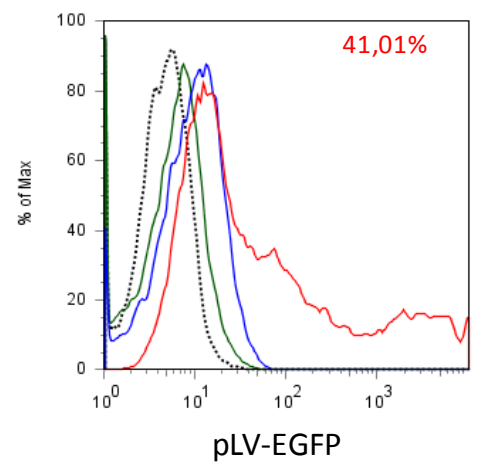

Figura 10 - Verificação da funcionalidade do vetor plasmideal pLV-EGFP através da lipofecção em linhagem celular 293T. (A) e (B): Fotografias da microscopia de fluorescência mostrando a lipofecção das células usando Lipofectamine ${ }^{\mathrm{TM}} 2000$, após 24 (A) e 48 (B) horas da transfecção. As imagens da esquerda foram tiradas com luz branca e as da direita com luz fluorescente após 4 segundos de exposição. (C) e (D): Histogramas indicativos da porcentagem de transfecção das células com o vetor pLV-EGFP usando lipofectamina 2000, após 24 (C) e 48 (D) horas da transfecção. As linhas pontilhadas representam as células não transfectadas, em linhas verdes estão as células tratadas apenas com agente de transfecção, em linhas azuis estão as células tratadas com o vetor pLV vazio, e as linhas vermelhas representam a transfecção com pLV-EGFP. Na parte superior de cada gráfico estão os valores da porcentagem de células transfectadas.

\subsubsection{Eletroporação das DCs}

Uma vez confirmada a funcionalidade da construção plasmideal, partiu-se para a transferência gênica nas DCs. Devido a facilidade de realização da técnica, e por não necessitar de reagentes adicionais, a eletroporação foi, inicialmente, estudada, com uso do pLV-EGFP, em DCs imaturas. Dois diferentes protocolos foram avaliados (Item 3.7). Em um deles a eletroporação procedeu no meio de glicose a $5 \%$ e no outro os procedimentos foram feitos no meio RPMI. Em ambos os protocolos, diversos parâmetros foram testados, como a variação dos volumes finais na cubeta e as capacitâncias. Sendo assim, utilizou-se para transfectar $20 \mu \mathrm{g}$ de pLV-EGFP e volumes finais de 0,2, 0,5, e $1 \mathrm{~mL}$ em cubeta de 0,4cm. Avaliou-se a eletroporação usando uma voltagem de $300 \mathrm{~V}$ e capacitâncias de 25 e $150 \mu \mathrm{F}$. A análise no citômetro de fluxo foi feita 24 e/ou 48 horas após a eletroporação. 
Conforme pode ser observado na Tabela 6, após 24 horas, a eletroporação em $1 \mathrm{~mL}$ de glicose a $25 \mu \mathrm{F}$ levou $6 \%$ das células a expressarem EGFP, havendo um aumento para 13\% quando passadas 48 horas. Para estas mesmas condições, mudando apenas a capacitância para $150 \mu \mathrm{F}$, houve diminuição na eficiência da transfecção que foi de 0 a 1,4\%, em 24 horas. As células transfectadas com 0,2mL de glicose e capacitância de $150 \mu \mathrm{F}$ mostraram 2\% das células positivas, 24 horas após a transfecção. Quando observadas após 48 horas, notou-se um aumento na porcentagem destas células expressando EGFP para 4\%. No caso do meio estudado RPMI, de três experimentos realizados, apenas um deles apresentou positividade com $14 \%$ das células expressando a proteína fluorescente (Tabela 6).

De acordo com os dados observados, pode-se dizer que para a técnica de eletroporação, até então, a melhor eficiência conseguida foi com os seguintes parâmetros: $1 \mathrm{~mL}$ de glicose $5 \%$ a $25 \mu \mathrm{F}$. Embora a porcentagem de células positivas tenha sido levemente maior quando foi usado o meio RPMI.

Tabela 6 - Porcentagem de células expressando EGFP, observadas após 24 e/ou 48 horas da eletroporação com diferentes combinações de meio (glicose $5 \%$ ou RPMI), em volumes finais na cubeta de $0,2,0,5$ ou $1 \mathrm{~mL}$, e com capacitâncias de $25 \mu \mathrm{F}$ ou $150 \mu \mathrm{F}$.

\begin{tabular}{|c|c|c|c|c|c|}
\hline & & \multicolumn{4}{|c|}{ Células expressando EGFP (\%) } \\
\hline & & \multicolumn{2}{|c|}{24 horas } & \multicolumn{2}{|c|}{48 horas } \\
\hline & & \multicolumn{2}{|c|}{ Capacitância } & \multicolumn{2}{|c|}{ Capacitância } \\
\hline & & $25 \mu \mathrm{F}$ & $150 \mu \mathrm{F}$ & $25 \mu \mathrm{F}$ & $150 \mu \mathrm{F}$ \\
\hline \multirow[t]{2}{*}{ Glicose 5\% } & $0,2 \mathrm{~mL}$ & não testado & 2,2 * & não testado & 3,8 * \\
\hline & $1 \mathrm{~mL}$ & 5,9 * & $0-1,5^{* *}$ & $13,2^{*}$ & não testado \\
\hline RPMI & $0,5 \mathrm{~mL}$ & não testado & não testado & $0-13,8^{* * *}$ & não testado \\
\hline
\end{tabular}

Desta forma, algumas mudanças no protocolo foram realizadas para obtenção de uma eletroporação mais eficiente. Diminuiu-se a concentração de pLV-EGFP de $20 \mu \mathrm{g}$ para $1 \mu \mathrm{g}$ e foi usado 10 vezes menos células. O meio escolhido foi $0,5 \mathrm{~mL}$ de glicose a 5\%. Assim, com estas condições, dentre as capacitâncias estudadas, àquela que mostrou maior eficiência foi de $150 \mu \mathrm{F}$ (33\%) em comparação com a de $25 \mu \mathrm{F}$, em que se observou $21 \%$ das células expressando EGFP (Figura 11). 


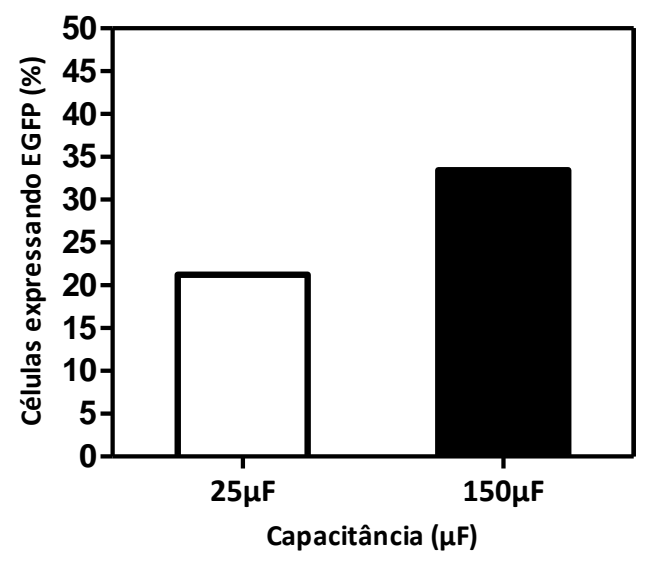

Figura 11 - Eletroporação das DC imaturas com pLV-EGFP em glicose 5\%. Gráfico representativo da porcentagem de células expressando EGFP, após eletroporação de $10^{6}$ células com $0,5 \mathrm{~mL}$ de glicose $5 \%$, a $300 \mathrm{~V}$ e, usando as capacitâncias de $25 \mu \mathrm{F}$ ou $150 \mu \mathrm{F}$.

Com esta técnica, em todas as condições estudadas, nota-se uma modificação na morfologia das células, que se apresentam menores e mais granulosas (Figura 12). Por este motivo, as DCs submetidas à eletroporação foram marcadas com iodeto de propídeo (PI) e anexina-V, para verificação da viabilidade celular, avaliada por citometria de fluxo. Quando foi utilizada uma capacitância de $25 \mu \mathrm{F}$, nota-se que apenas $28 \%$ (no caso de DCs eletroporadas sem DNA) e $25 \%$ (no caso das DCs eletroporadas com vetor vazio pLV) das células permanecem viáveis. Já com a capacitância de $150 \mu \mathrm{F}$, cerca de $39 \%$ das células foram viáveis, tanto para as DCs eletroporadas sem DNA, quanto para aquelas eletroporadas com o vetor vazio pLV (Figura 13). De maneira geral, observa-se mais de 50\% de células mortas após o choque elétrico, em ambos os parâmetros testados. Ainda, a presença do DNA não parece ser a causa da morte celular, nestes casos, já que não houve um aumento significante na porcentagem de células mortas. Existe uma diferença sutil entre o tipo de morte celular causada quando foram aplicados os diferentes valores de capacitância. Com $25 \mu \mathrm{F}$, pode-se visualizar uma pequena população (aproximadamente $8 \%$ ) de células que está em apoptose inicial, identificada pela marcação simples com anexina-V. Com $150 \mu \mathrm{F}$, observa-se que houve praticamente apenas células necróticas, identificadas pela marcação simples com PI (Figura 13). 


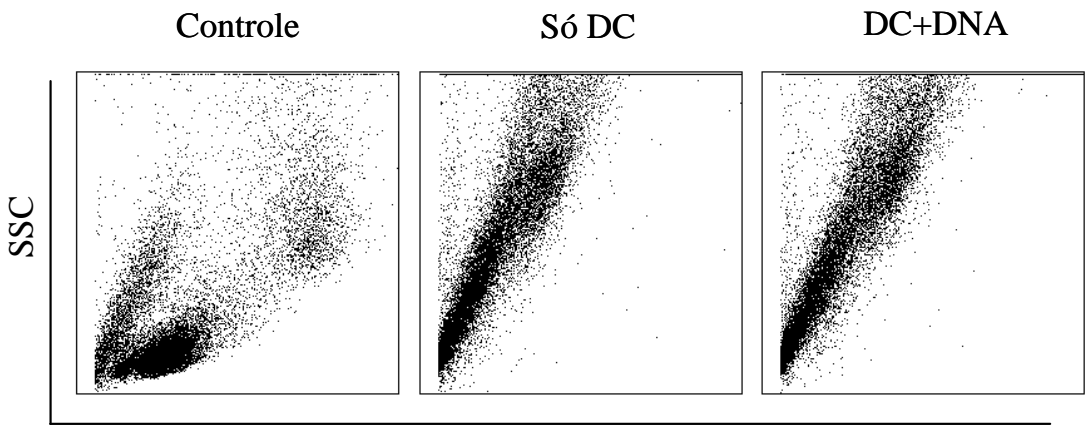

FSC

Figura 12 - Morfologia das células após eletroporação. Gráficos representativos das populações de células em tamanho (FSC) por granulosidade (SSC), antes e após eletroporação. Da esquerda para direita, estão células antes da eletroporação, células eletroporadas sem nada e células eletroporadas com DNA-EGFP. Nesse caso foram usadas $10^{6}$ células em $0,5 \mathrm{~mL}$ de glicose $5 \%$, a $300 \mathrm{v}$ e $150 \mu \mathrm{F}$.
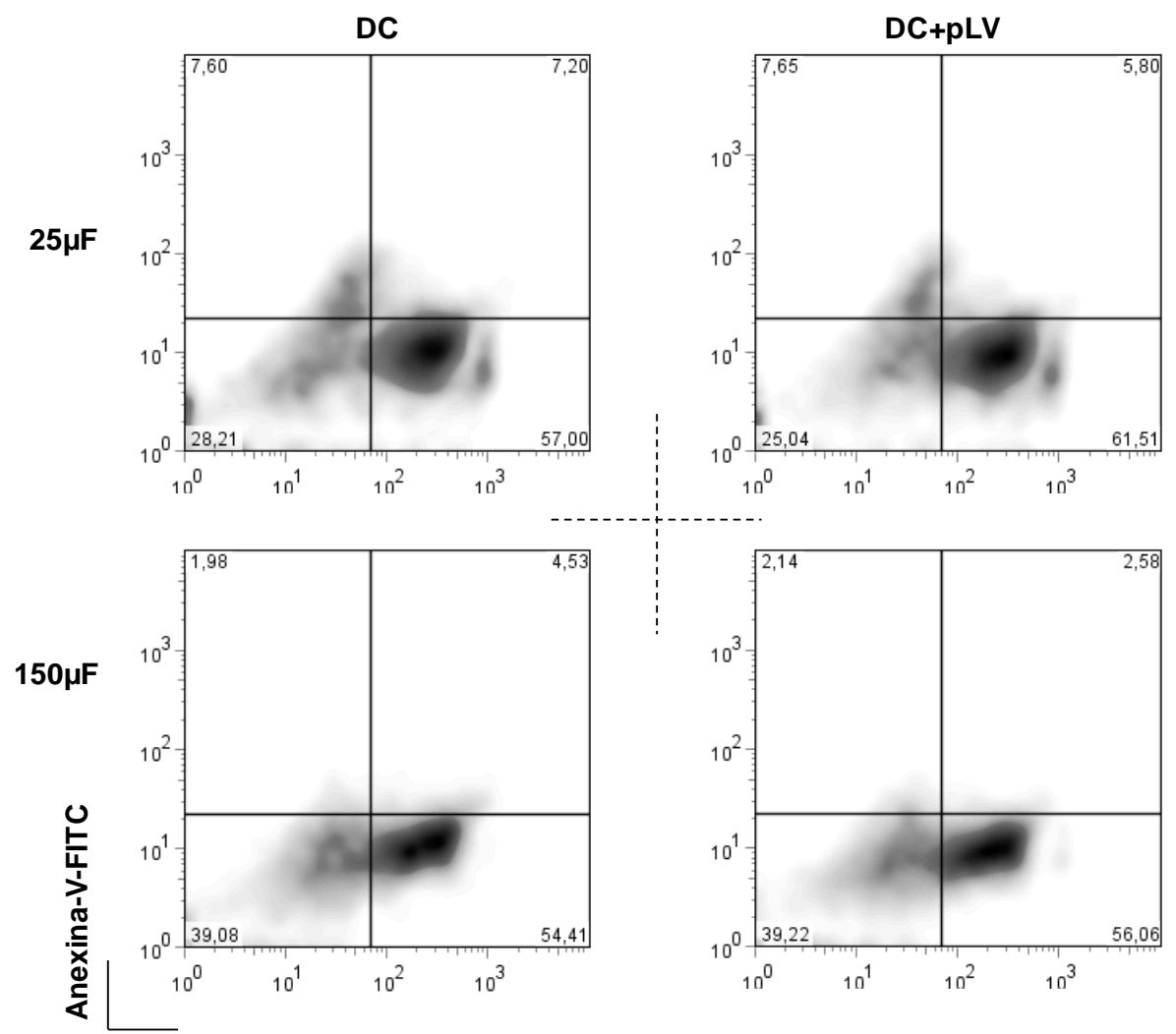

lodeto de Propídeo (PI)

Figura 13 - Gráficos representativos da viabilidade celular após eletroporação. As células foram marcadas com anexina-V e iodeto de propídeo (PI) para avaliar a viabilidade celular. As células $\mathrm{Pl}^{+}$anexina são consideradas necróticas, as células $\mathrm{Pl}^{-}{ }^{-}$nexina ${ }^{+}$são consideradas em apoptose inicial, as células $\mathrm{PI}^{+}$anexina ${ }^{+}$são consideradas em apoptose tardia e as células Pl'anexina são consideradas vivas. Acima: representa DCs eletroporadas sem nada (à esquerda) e DCs eletroporadas com vetor vazio pLV (à direita) numa capacitância de $25 \mu \mathrm{F}$. Abaixo: representa DCs eletroporadas sem nada (à esquerda) e DCs eletroporadas com vetor vazio pLV (à direita) numa capacitância de $150 \mu \mathrm{F}$. Neste experimento foram usadas $10^{6}$ células em $0,5 \mathrm{~mL}$ de glicose $5 \%$, a 300v. 


\subsubsection{Lipofecção das DCs}

Em paralelo a eletroporação, foi explorada a técnica de lipofecção das DCs. Num primeiro momento, foi estudada a transfecção em DCs maduras (mDCs) e DCs imaturas (iDCs) cultivadas no meio R10, afim de definir o melhor estágio de maturação para realização desta técnica. Assim, no quinto dia de cultura foi adicionado TNF-alfa para maturação das células e obtenção das $\mathrm{mDCs}$, enquanto as iDCs foram mantidas em meio de cultura até sétimo dia, afim de obter-se as duas formas de maturação de um único doador e transfectar as células no mesmo dia com as mesmas condições. Tais células foram transfectadas com o agente de transfecção lipofectamina 2000, neste caso, por complexos contendo diferentes quantidades de plasmídeo pLV-EGFP (1, 2 e 4 ug) e do agente de transfecção na proporção de 1:8, respectivamente. A proporção de células fluorescentes foi avaliada após 48 horas, em microscópio de fluorescência.

Houve detecção de fluorescência apenas nas iDCs, sendo os melhores resultados obtidos através da utilização de $1 \mu \mathrm{g}$ de plasmídeo pLV-EGFP (Figura 14), embora, ainda assim, a eficiência da transfecção tenha sido muito baixa (uma ou nenhuma célula fluorescente por campo). As demais concentrações pareceram tóxicas para as células (dados não mostrados). Portanto, baseado nestes resultados prévios e em dados da literatura que mostram a transfecção mais eficiente quando realizada nas iDCs, nos experimentos seguintes priorizou-se o uso destas células para padronizar a melhor forma de transferência gênica. Ainda, optou-se por estudar concentrações de DNA em torno de $1 \mu \mathrm{g}$, além de diminuir a proporção DNA/lipossomos, a fim de tentar reduzir a toxicidade celular. Dois outros agentes de transfecção foram testados, Gene Juice® e Turbofect, com os quais não se observaram resultados satisfatórios (dados não mostrados). 

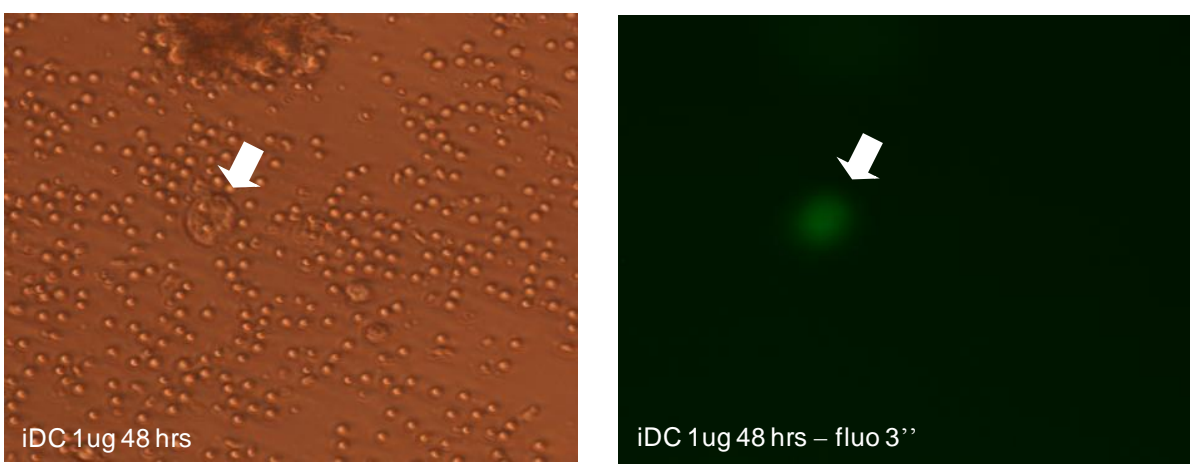

Figura 14 - Fotografias de microscopia de fluorescência indicativas da lipofecção das DCs. A lipofecção foi feita com lipofectamina 2000 e avaliada após 48 horas. A imagem da esquerda foi tirada com luz branca e a da direita com luz fluorescente após 3 segundos de exposição. As setas brancas indicam as células contendo o plasmídeo pLV/EGFP. Representativo de 2 experimentos.

Nova estratégia de transfecção com lipofectamina 2000 foi adotada empregando-se, agora, o meio de cultura AIM-V para o cultivo das DCs e para a transfecção, ao invés do meio R10, utilizado anteriormente. Para os procedimentos de transfecção, os meios de cultura, preferencialmente, não devem conter SFB, presente no R10, mas não no AIM-V. O soro pode reduzir a eficiência da metodologia, pois a sua presença interfere com a formação dos complexos DNA/lipossomos. Por isso, nos experimentos anteriores, as células eram transfectadas em meio RPMI e, em seguida lavadas e transferidas para meio R10. Então passou a ser utilizado o meio AIM-V, a fim de reduzir o número de manipulações com as DCs, e assim, as transfecções poderiam ser feitas diretamente neste meio sem necessitar dos demais procedimentos, como no caso do R10. As transfecções foram feitas, no quinto dia da cultura, em iDCs empregando-se diferentes quantidades do agente de transfecção lipofectamina 2000 e de plasmídeo

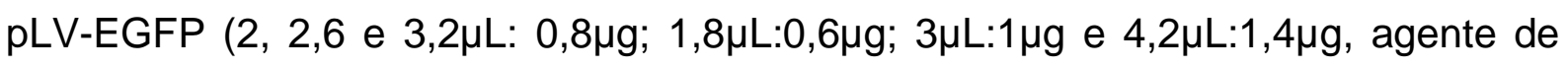
transfecção: plasmídeo pLV-EGFP).

Após 48 de transfecção, observaram-se, por citometria de fluxo, que as DCs expressavam a proteína EGFP variando na porcentagem de células positivas (35$43 \%$ ), de acordo com as quantidades de plasmídeo e agente de transfecção usadas (Figura 15). 


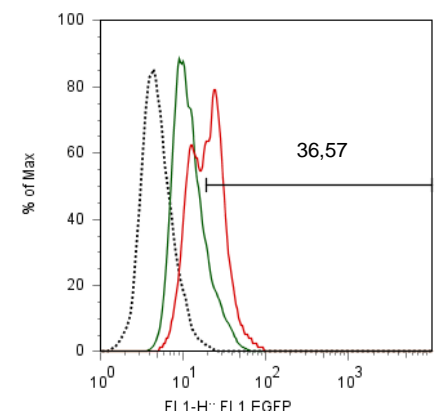

$0,6 \mu \mathrm{g} \mathrm{pLV} / \mathrm{EGFP}$

$1,8 \mu \mathrm{L}$ Lipofectamine ${ }^{\mathrm{TM}} 2000$

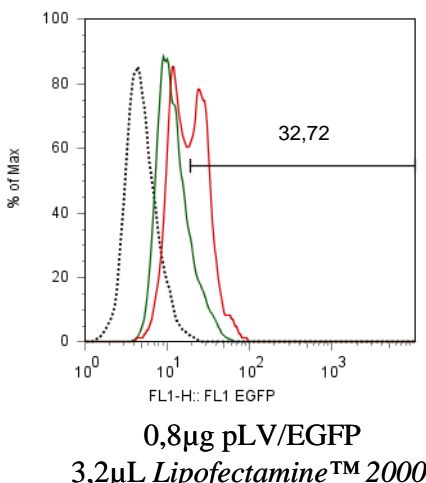

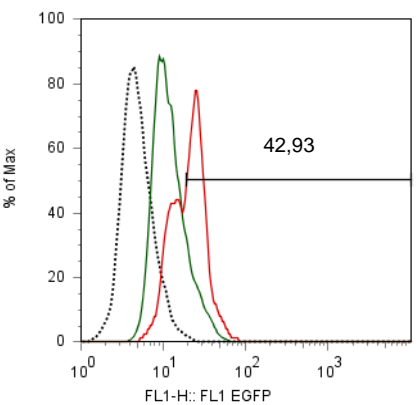

$0,8 \mu \mathrm{g} \mathrm{pLV/EGFP}$

$2 \mu \mathrm{L}$ Lipofectamine ${ }^{\mathrm{TM}} 2000$

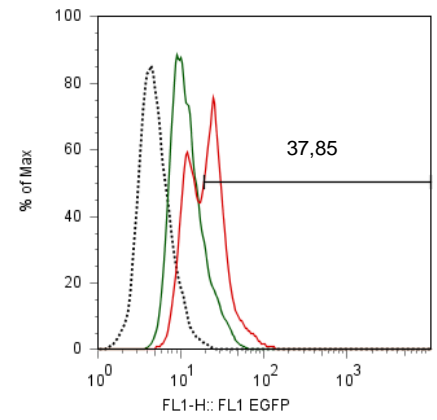

$1 \mu \mathrm{g} \mathrm{pLV/EGFP}$

$3 \mu \mathrm{L}$ Lipofectamine ${ }^{\mathrm{TM}} 2000$

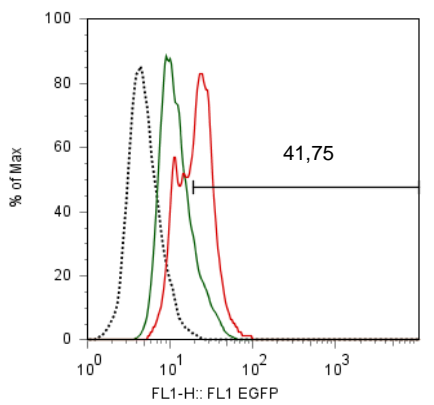

$0,8 \mu \mathrm{g} \mathrm{pLV/EGFP}$

$2,6 \mu \mathrm{L}$ Lipofectamine ${ }^{\mathrm{TM}} 2000$

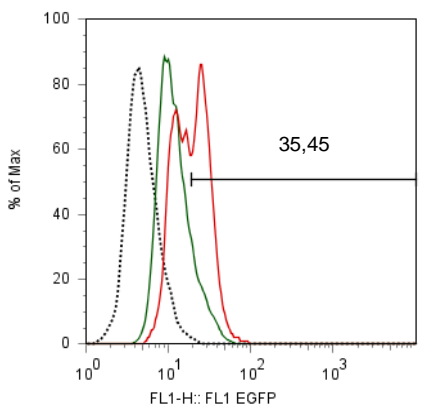

$1,4 \mu \mathrm{g} \mathrm{pLV} / \mathrm{EGFP}$

$4,2 \mu \mathrm{L}$ Lipofectamine ${ }^{\mathrm{TM}} 2000$

Figura 15 - Histogramas representativos da porcentagem de lipofecção das DCs imaturas, em meio AIM-V, com diferentes concentrações de pLV/EGFP e lipossomos. As concentrações de pLV-EGFP e agente de transfecção usadas estão especificadas abaixo de cada gráfico. As linhas pontilhadas representam as DCs sem tratamento, em linhas verdes estão as DCs tratadas apenas com agente de transfecção e as linhas vermelhas representam as populações especificas de cada tratamento com DNA e agente de transfecção. As análises foram feitas englobando as células que no gate SSCXFSC eram CD11c e HLA-DR ${ }^{+}$, e nestas células foram delimitados, nos histogramas, gates no limite entre as células tratadas apenas com agente de transfecção e as transfectadas.

Nos histogramas apresentados, nota-se a presença bem nítida de duas populações, uma delas parece ter sido transfectada enquanto que a outra não. No limite delas foi feito o gate de análise eliminando-se a interferência de 16,29\% de células que foram fluorescentes apenas pelo tratamento com o agente de

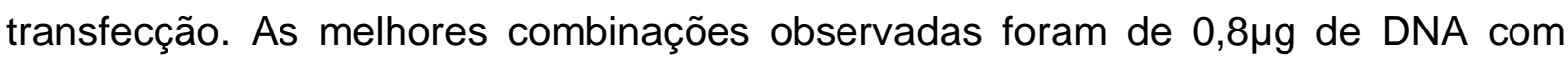
$2 \mu \mathrm{L}$ de agente de transfecção (43\% de células positivas) e de $0,8 \mu \mathrm{g}$ de DNA com $2,6 \mu \mathrm{L}$ de agente de transfecção (42\% de células positivas). Estes grupos também mostraram uma quantidade menor de células na população não transfectada, representadas nos histogramas pelos picos menores, em comparação com a subpopulação de células não transfectadas dos outros grupos (Figura 15). Ainda neste aspecto, das duas populações observadas, uma delas tinha baixa expressão de CD86 (low) enquanto a outra tinha uma expressão maior (high). Então, optou-se 
por fazer um gate (L, para a população low e H, para a população high) delimitando cada população e avaliar qual delas estava transfectando. Os resultados mostraram que, em todos os grupos, as populações com baixa expressão de CD86 eram positivas e as que expressavam CD86 high não estavam transfectando (Figura 16).
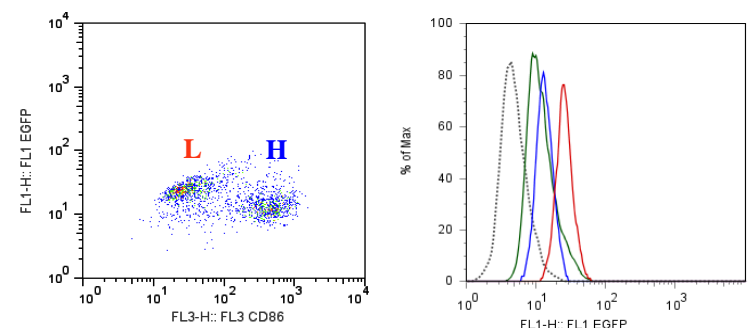

$0,6 \mu \mathrm{g} \mathrm{pLV/EGFP}$

$1,8 \mu \mathrm{L}$ Lipofectamine ${ }^{\mathrm{TM}} 2000$
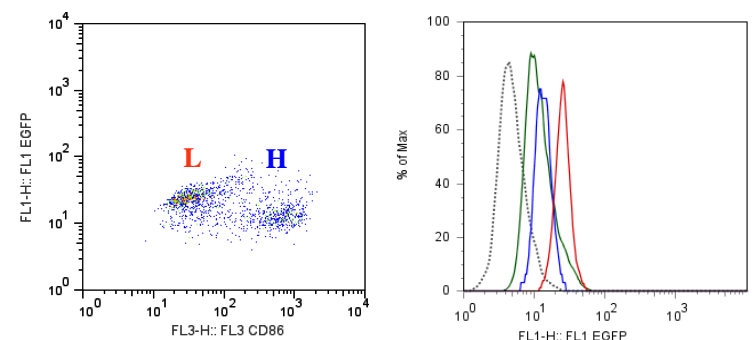

$0,8 \mu \mathrm{g} \mathrm{pLV/EGFP}$

$2 \mu \mathrm{L}$ Lipofectamine ${ }^{\mathrm{TM}} 2000$
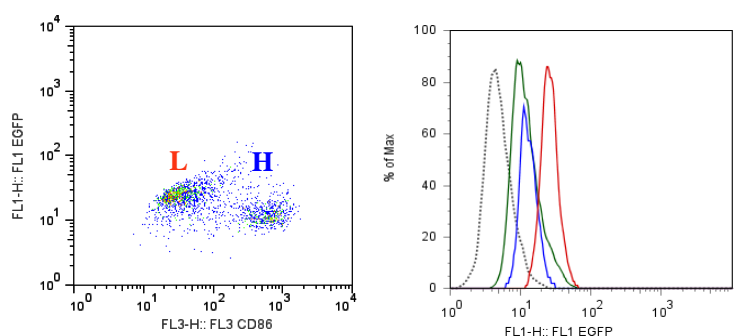

$0,8 \mu \mathrm{g} \mathrm{pLV/EGFP}$

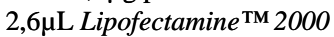
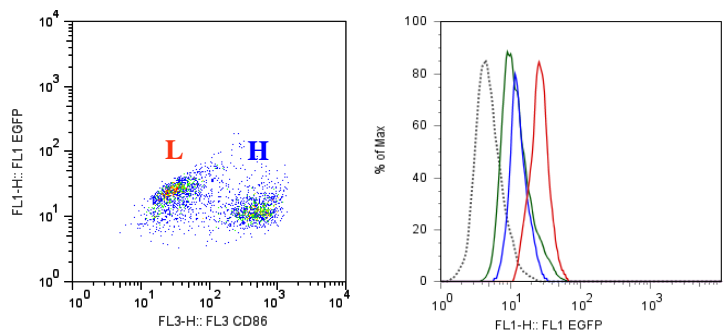

$0,8 \mu \mathrm{g} \mathrm{pLV} / \mathrm{EGFP}$

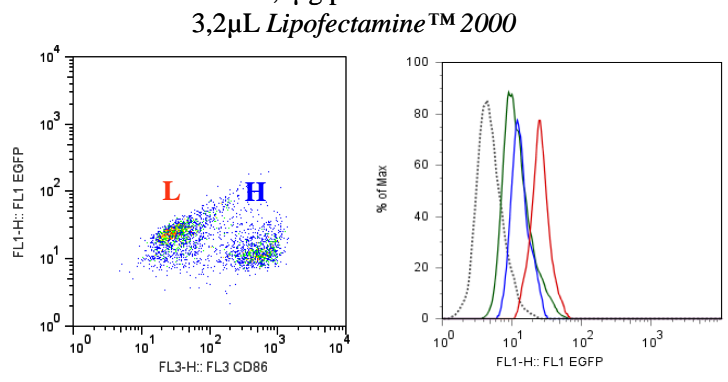

$1 \mu \mathrm{g} \mathrm{pLV/EGFP}$

$3 \mu \mathrm{L}$ Lipofectamine ${ }^{\mathrm{TM}} 2000$
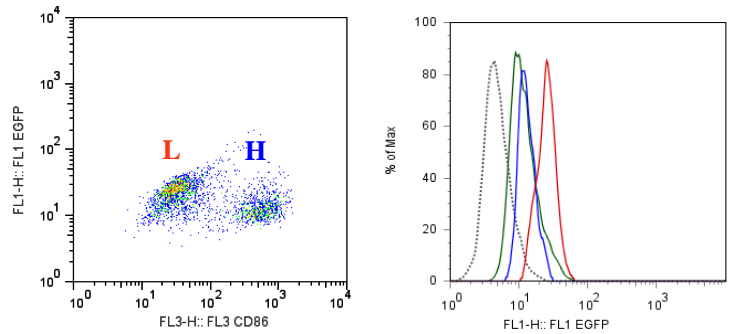

$1,4 \mu \mathrm{g} \mathrm{pLV} / \mathrm{EGFP}$

$4,2 \mu \mathrm{L}$ Lipofectamine ${ }^{\mathrm{TM}} 2000$

Figura 16 - Comparação da transfecção do pLV-EGFP entre as populações de DCs com alta e baixa expressão de CD86. Após a transfecção com o vetor plasmideal pLV-EGFP, foram verificadas duas populações de DCs expressando CD86 e em cada população foram feitos gates específicos. A análise das populações de CD86 foram feitas nas células que no gate SSCxFSC eram CD11c ${ }^{+}$e HLA-DR ${ }^{+}$. L: delimita a população CD86 low e H: delimita a população CD86 high. Nos histogramas estão representados em azul a população do gate $\mathrm{H}$ e em vermelho a população do gate $\mathrm{L}$. As linhas pontilhadas representam as DCs sem tratamento e em linhas verdes estão as DCs tratadas apenas com agente de transfecção.

Apesar de ter mostrado bons resultados, a transfecção das DCs no meio AIM$V$ causou, em todos os grupos, diminuição em tamanho e granulosidade das células transfectadas, permanecendo uma população esparsa quando se compara com o grupo controle (apenas lipofectamina) (Figura 17A). 
Para tentar contornar este problema, o próximo passo foi, então, repetir o mesmo experimento, empregando, no momento da transfecção, o meio de cultura RPMI, sem antibióticos e SBF. A transfecção no RPMI foi realizada com as mesmas proporções de plasmídeo e agente de transfecção descritas acima. Desta vez, não se observaram mudanças no tamanho e granulosidade das células (Figura 17B). Contudo, a porcentagem de células expressando EGFP foi praticamente nula (0-5\%) (dados não mostrados), mostrando que com a mudança do meio de cultura, não houve alteração morfológica das DCs, mas também não houve transfecção.

$\mathbf{A}$

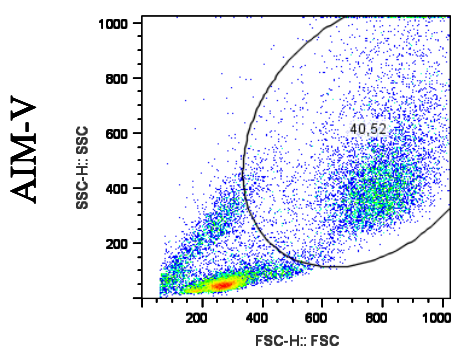

$2 \mu \mathrm{L}$ Lipofectamine TM $^{\mathrm{TM}} 2000$

$\mathbf{B}$

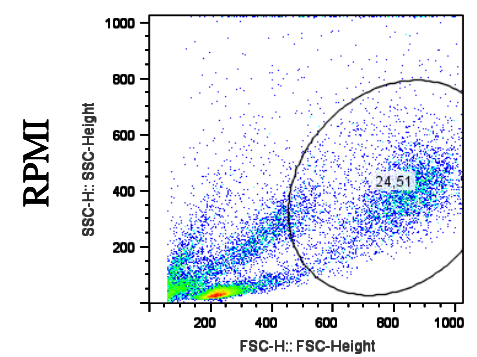

$2 \mu \mathrm{L}$ Lipofectamine $^{\mathrm{TM}} 2000$
48 horas

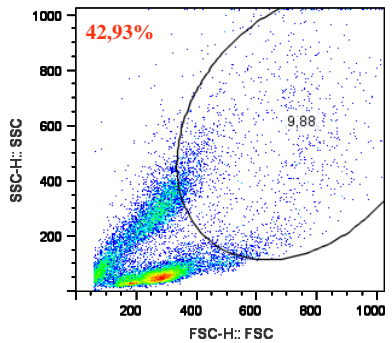

$0,8 \mu \mathrm{g}$ pLV/EGFP

$2 \mu \mathrm{L}$ Lipofectamine ${ }^{\mathrm{TM}} 2000$

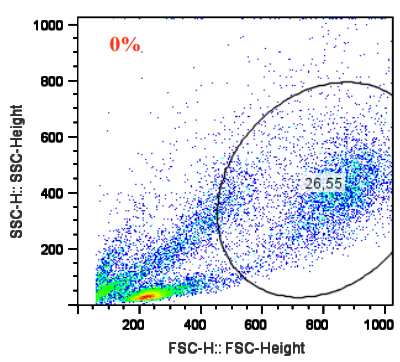

$0,8 \mu \mathrm{g} \mathrm{pLV} / \mathrm{EGFP}$ $2 \mu \mathrm{L}$ Lipofectamine $^{\mathrm{TM}} 2000$

Figura 17 - Comparação das populações de células transfectadas com pLV-EGFP nos meios de cultura AIM-V e RPMI. Gráficos pseudo-coloridos de tamanho (FSC) por granulosidade (SSC), em que se delimitou um gate para as células com tamanho e granulosidade característicos de células dendríticas, após 48 horas da transfecção com $0,8 \mu \mathrm{g}$ de pLV-EGFP e $2 \mu \mathrm{L}$ de agente de transfecção, nos meios AIM-V (A) e RPMI (B). Os valores em vermelho indicam a porcentagem de células transfectadas. FSC: forward scatter, SSC: side scatter. 


\subsection{Síntese do mRNA de antígenos específicos}

Antes de transfectar as DCs com mRNA, uma série de procedimentos foram necessários para que fosse possível produzi-lo in vitro. Uma das exigências para transcrição in vitro é a presença de um molde de cDNA que contenha as regiões promotoras das enzimas polimerases SP6 ou T7. Isto porque são elas as responsáveis pela síntese da fita de RNA. Além disso, estes moldes, no caso plasmídeos, devem estar linearizados. Neste trabalho, optamos por produzir o mRNA da proteína fluorescente EGFP e dos antígenos tumorais survivina e RPSA.

\subsubsection{Clonagem do EGFP no plasmídeo pGEM-T Easy}

Para servir como controle da eficácia da transcrição in vitro e detecção das células efetivamente transfectadas, o mRNA do gene EGFP foi escolhido, pois além da fácil detecção, não é expresso endogenamente pelas DCs. Para isto, o cDNA do EGFP foi clonado em um vetor que apresentasse os promotores SP6 e T7, neste caso o pGEM-T Easy. Em um primeiro momento, o mRNA do EGFP foi transfectado na linhagem celular 293T, em que esta técnica já está bem estabelecida.

Para clonagem do EGFP no vetor pGEM-T Easy procedeu-se conforme descrito no item 3.10.1. A fim de determinar se houve clonagem do cDNA do EGFP no vetor pGEM-T Easy foi realizada uma digestão com a enzima EcoRI (Figura 18A). Caso a clonagem tivesse ocorrido, os fragmentos esperados seriam de $3000 \mathrm{pb}$ e $730 \mathrm{pb}$. Observou-se que apenas um dos vetores analisados (canaleta 1) possui o perfil esperado. Para avaliar o sentido do EGFP com relação aos promotores T7 e SP6 nesse vetor, seguiu-se com a determinação do perfil de restrição com as enzimas Ncol, Sall, Pstl que reconhecem sítios no vetor pGEM-T Easy e com enzima Hindlll que reconhece um único sítio no cDNA do EGFP (Figura 18B, canaletas 2, 3 e 4). Foi realizada a co-digestão com a combinação das enzimas $\mathrm{Ncol}$ e HindlII (canaleta 2), com tamanho de fragmentos esperado 730pb e $3000 \mathrm{pb}$, caso a orientação da fase de leitura do EGFP estivesse relacionado ao promotor T7, Sall e HindIII (canaleta 3) e Pstl e HindllI (canaleta 4), com tamanho de fragmentos esperado $730 \mathrm{pb}$ e $3000 \mathrm{pb}$, caso a orientação da fase de leitura do EGFP estivesse relacionado ao promotor SP6. Os tamanhos dos fragmentos esperados para todas essas digestões estão detalhados na Tabela 3. O vetor pGEM-T Easy vazio foi 
digerido com as mesmas combinações das enzimas usadas para digerir o vetor pGEM-T Easy-EGFP para servir como controle da funcionalidade da reação de restrição. Sendo assim, na canaleta 5 está representada a co-digestão com as enzimas Ncol e HindlII, na canaleta 6 a co-digestão com as enzimas Sall e HindIII e na canaleta 7 a co-digestão com as enzimas Pstl e Hindlll, todas elas com um fragmento esperado de 3700pb (Figura 18B).
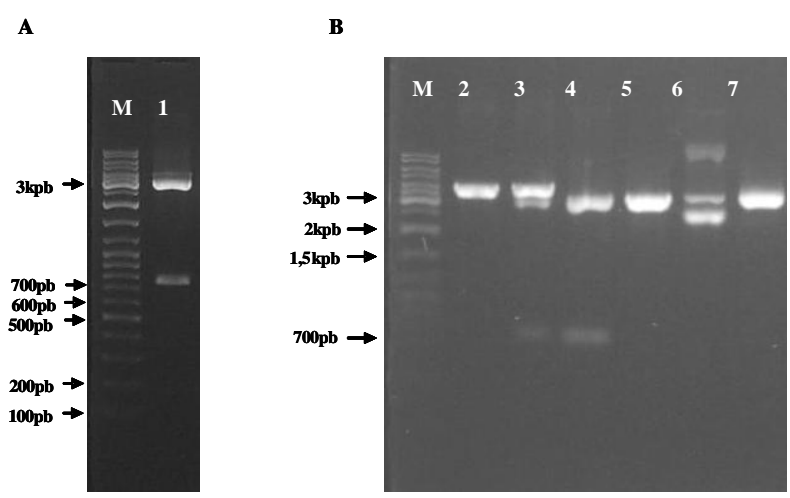

Figura 18 - Perfil de restrição do vetor pGEM-T Easy-EGFP. Fotografia da eletroforese em gel de agarose $1 \%$ para analisar se houve clonagem e qual a orientação do cDNA do EGFP, com relação aos promotores SP6 e T7, com base nos seus perfis de digestão. A: A enzima de restrição usada para verificar se houve clonagem foi EcoRI com fragmentos esperados de 3000 e 730pb (canaleta 1), correspondentes aos tamanhos do vetor e do EGFP, respectivamente. B: Perfil de restrição observado após a digestão do vetor pGEM-T Easy-EGFP, para identificar a orientação de clonagem do cDNA da EGFP. As canaletas 2, 3 e 4 representam a digestão do vetor pGEM-T Easy-EGFP e as canaletas 5, 6, 7 representam a digestão do vetor pGEM-T Easy (vazio). Os fragmentos esperados para a co-digestão com as enzimas Ncol e Hindlll eram de 3000 e 730pb (canaleta 2), caso a orientação da fase de leitura do EGFP estivesse relacionado ao promotor T7. Os fragmentos esperados para a co-digestão com as enzimas Sall e Hindlll e co-digestão com as enzimas Pstl e Hindlll eram de 3000 e $730 \mathrm{pb}$, caso a orientação da fase de leitura do EGFP estivesse relacionado ao promotor SP6 (canaletas 3 e 4). Os fragmentos esperados para as co-digestões do vetor vazio, com as três combinações de enzimas, eram de $3700 \mathrm{pb}$. M: marcador de peso molecular.

Como pode ser observado na Figura 18B, houve digestão parcial do vetor pGEM-T Easy-EGFP com a combinação das enzimas Sall e HindIII, observada pela presença de bandas de alto peso molecular correspondentes ao vetor não digerido (canaletas 3 e 6). Esse fenômeno foi devido à incompatibilidade das condições ideais de reação para as duas enzimas atuarem.

De maneira geral, o perfil de restrição obtido indica que o cDNA da EGFP está clonado na orientação do promotor SP6. Portanto, pode-se realizar a linearização do vetor para dar continuidade com a transcrição in vitro do EGFP. Para a linearização do pGEM-T Easy-EGFP, foi usada a enzima de restrição EcoRI. O 
tamanho do fragmento esperado era de 3730pb referente aos tamanhos do vetor pGEM-T Easy (3015pb) somado ao cDNA do EGFP ( 700pb) (dados não mostrados).

\subsubsection{Obtenção e linearização das regiões codificadoras dos antígenos tumorais RPSA e survivina}

Para obtenção das regiões codificadoras dos antígenos escolhidos RPSA e Survivina, super-expressos pelas células leucêmicas, optou-se pelo uso de clones disponíveis na biblioteca de cDNAs MGC do consórcio IMAGE, que possuem as seqüências codificadoras dos antígenos sem mutações, clonadas em plasmídeos com os promotores T7 e SP6 e transformadas em bactérias, sendo necessário apenas extrair e linearizar o vetor para dar continuidade aos experimentos.

A orientação, em relação aos promotores T7 e SP6, dos cDNAs da RPSA e Survivina clonados nos plasmídeos pCMV-SPORT6 e pOTB7, respectivamente, foi identificada pelas digestões com as enzimas de restrição descritas na metodologia (Item 3.10.2). O resultado deste perfil de restrição está representado na Figura 19.

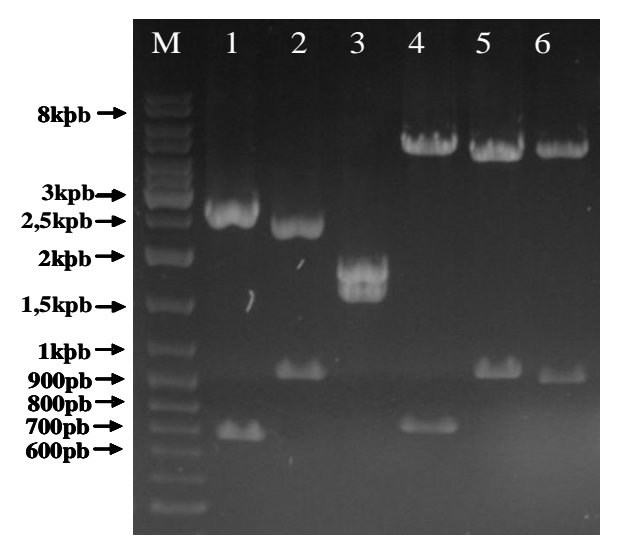

Figura 19 - Perfil de restrição dos vetores pOTB7-survivina e pCMV-SPORT6-RPSA. Fotografia da eletroforese em gel de agarose 1\% para análise da orientação dos cDNAs da survivina e RPSA, com relação aos promotores SP6 e T7, com base nos seus perfis de digestão. As enzimas de restrição usadas para análise da orientação de clonagem da survivina com seus respectivos fragmentos esperados, caso a orientação estivesse no sentido do SP6, foram Ncol, com fragmentos de 2694 e 774pb (canaleta 1), Smal, com fragmentos de 2560 e $908 \mathrm{pb}$ (canaleta 2), EcoRI e Xhol, com fragmentos de 1815 e $1653 \mathrm{pb}$ (canaleta 3). As enzimas de restrição usadas para identificar a orientação de clonagem da RPSA com seus respectivos fragmentos esperados, caso a orientação estivesse no sentido do SP6, foram Hindlll, com fragmentos de 4601 e 830pb (canaleta 4), Ncol, com fragmentos de 4361 e 1072pb (canaleta 5), Notl e Sall, com fragmentos de 4396 e 1037pb (canaleta 6). M: marcador de peso molecular. 
No caso da análise do perfil de restrição relacionado ao clone pOTB7survivina, foram utilizadas enzimas (Ncol, Smal, EcoRl e Xhol) que reconhecem sítios tanto no vetor como no cDNA. Mais especificamente, as enzimas Ncol (canaleta 1) e Smal (canaleta 2) reconhecem um sítio presente no vetor e outro no cDNA, e as enzimas EcoRl e Xhol (canaleta 3) reconhecem sítios de restrição apenas no vetor. Da mesma forma, na análise do perfil de restrição relacionado ao vetor pCMV-SPORT6-RPSA, foram utilizadas enzimas (HindlII, Ncol, Notl e Sall) que reconhecem sítios no vetor e no cDNA. As enzimas Hindlll e Ncol (canaletas 4 e 5 , respectivamente) reconhecem um sítio no vetor e outro sítio no cDNA da RPSA, e as enzimas Notl e Sall (canaleta 6) reconhecem sítios apenas no vetor. Os tamanhos dos fragmentos esperados para todas essas digestões estão descritos na Tabela 4.

De maneira geral, os resultados obtidos, como observado na Figura 19, foram correspondentes ao perfil de restrição caso os cDNAs da survivina e da RPSA estivessem clonados na orientação do promotor SP6. Existe, apenas, uma pequena discrepância de aproximadamente 100pb para menos, nos fragmentos menores, no caso do pCMV-SPORT6-RPSA. Esse resultado deve ser confirmado posteriormente por seqüenciamento.

Com a orientação dos cDNAs da RPSA e Survivina clonados nos vetores pCMV-SPORT6 e pOTB7, respectivamente, conhecida, foi possível escolher uma enzima de restrição para linearizar os vetores e, desta forma, fazer a transcrição in vitro. Foram escolhidas enzimas que cortassem apenas o vetor, a 3' do cDNA clonado. Para linearizar o pOTB7-survivina foi usada a enzima Bglll e para o pCMVSPORT6-RPSA a enzima Xhol. O tamanho do fragmento esperado, no caso da restrição com BgllI, era de 3468pb referente aos tamanhos do vetor pOTB7 (1815pb) somado ao cDNA da survivina (1653pb), já no caso da restrição com Xhol, era de 5433pb referente aos tamanhos do vetor pCMV-SPORT6 (4396pb) somado ao cDNA da RPSA (1037pb). Como pode ser observado na Figura 20, foi conseguida a digestão completa de ambos os vetores, com os tamanhos dos fragmentos esperados. 


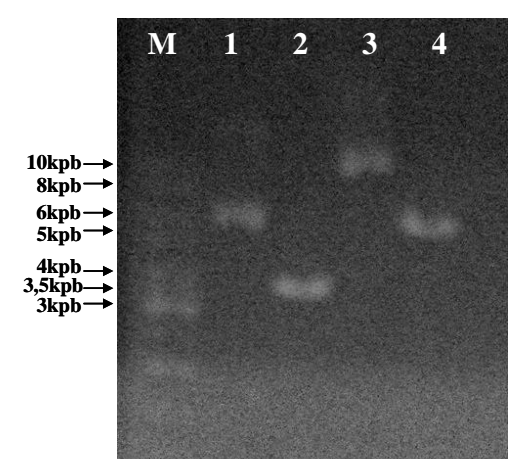

Figura 20 - Linearização dos vetores pOTB7-survivina e pCMV-SPORT6-RPSA. Fotografia da eletroforese em gel de agarose $1 \%$ para avaliar a linearização dos vetores. As canaletas 1 e 3 correspondem aos vetores pOTB7/survivina e pCMV-SPORT6/RPSA, respectivamente, não digeridos. A enzima de restrição usada para a digestão do pOTB7-survivina foi Bglll, gerando um fragmento de 3468pb (canaleta 2), e a enzima Xhol foi usada para linearizar o pCMV-SPORT6/RPSA, gerando um fragmento de 5433pb (canaleta 4). M: marcador de peso molecular.

\subsubsection{Transcrição in vitro do EGFP, RPSA e survivina}

Com os vetores linearizados, foi realizada a transcrição in vitro para produzir mRNA dos antígenos específicos, que seriam posteriormente transfectados em DCs. Como já foi dito anteriormente, espera-se que este mRNA seja traduzido nas células. É importante lembrar que nas células eucarióticas, após a transcrição, o transcrito primário de RNA sofre algumas modificações para que possa ser traduzido, tais como o splicing alternativo, além de duas outras modificações: o capeamento e caudeamento (adição da cauda poliA). No capeamento ocorre adição de uma base, diferente das demais que compõe o RNA, 7-metil-guanosina na sua extremidade 5'. Esta é importante para a ligação de fatores de iniciação da tradução, para o transporte núcleo-citoplasmático e proteção contra nucleases celular (BOCZKOWSKI e NAIR, 2010). Portanto, durante as manipulações in vitro para síntese de RNA, foi necessário adicionar o análogo do cap sintético. As condições da reação foram descritas nos métodos (Item 3.11). Deve-se considerar que as polimerases SP6 e T7 requerem o nucleotídeo GTP para iniciar a transcrição, porém só incorporam o análogo do Cap, como nucleotídeo 5', se este estiver em maior concentração do que o GTP. Por isso, foram utilizadas dez vezes menos GTP em comparação com os outros nucleotídeos, na reação de transcrição. 
A padronização desta técnica foi conseguida, como pode ser observado na Figura 21.

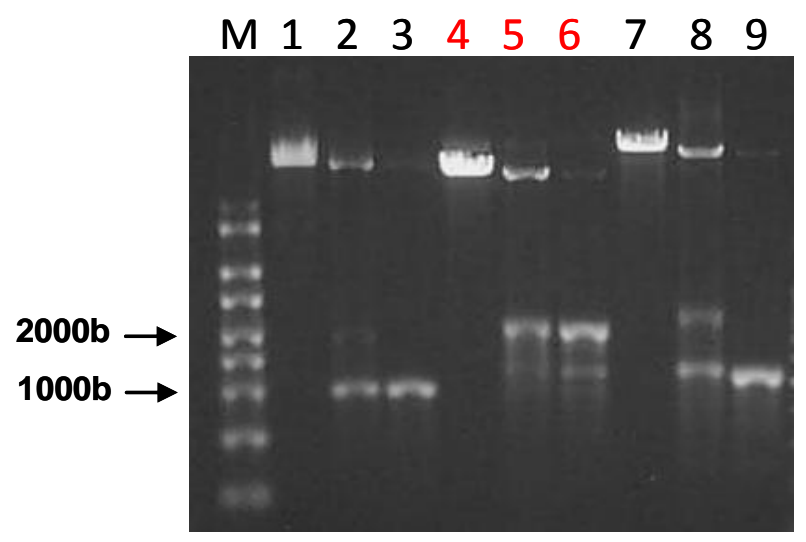

Figura 21 - Transcrição in vitro dos cDNAs do EGFP, survivina e RPSA. Fotografia da eletroforese em gel de agarose $1 \%$ para avaliar o produto da reação de transcrição in vitro. As canaletas 1, 2 e 3 correspondem ao EGFP, as canaletas 4,5 e 6 correspondem à survivina e as canaletas 7,8 e 9 correspondem à RPSA. Em 1, 4 e 7 estão os fragmentos de plasmídeo linearizado, referentes aos respectivos genes. As canaletas 2, 5 e 8 são correspondentes aos produtos transcritos antes da purificação e nas canaletas 3, 6 e 9 pós-purificação. M: marcador de peso molecular.

Na eletroforese em gel de agarose $1 \%$ foi possível notar, a presença de uma banda com aproximadamente 2000 bases, correspondente ao mRNA da região codificadora da survivina (1653pb) e parte do vetor, somado ao análogo Cap (Figura 21, canaleta 6). O mesmo foi encontrado para RPSA e EGFP, observando-se bandas de aproximadamente 1000 bases para ambos os transcritos, correspondentes às regiões codificadoras de $888 \mathrm{pb}$, no caso do RPSA (Figura 21, canaleta 9) e aproximadamente 730pb, no caso do EGFP (Figura 21, canaleta 3).

Obteve-se, na quantificação, cerca de 1000ng/ $\mathrm{LL}$ de RNA com uma pureza razoável, pois houve a presença de uma banda maior correspondente a resquícios de cDNA não transcrito (Figura 21, canaletas 2, 5 e 8 referentes a EGFP, survivina e RPSA). Contudo, após a purificação do produto da transcrição foi conseguido uma concentração de 100 a 300ng/ $\mu \mathrm{L}$ de RNA com uma ótima pureza, observada pela eliminação da banda correspondente ao cDNA (Figura 21, canaletas 3, 6 e 9). Ainda, na canaleta 6, aparece um fragmento menor do que as 2000 bases referente ao mRNA da survivina, que provavelmente deve ser transcrição de alguma região que a enzima SP6 reconhece inespecificamente. 


\subsection{Transfecção com mRNA dos antígenos tumorais}

Com as informações obtidas através da transfecção das DCs com DNA, e já dominada a técnica de transcrição in vitro, partiu-se para a transfecção com mRNA. Iniciou-se a padronização da transfecção com o uso do mRNA do antígeno survivina, freqüentemente super-expresso na LLC. A técnica escolhida foi a lipofecção com lipofectamina 2000, utilizando as condições empregadas anteriormente para o plasmídeo pLV-EGFP que foram mais eficientes. As transfecções foram, inicialmente, realizadas no meio de cultura AIM-V, já que para o DNA conseguiu-se melhores resultados com este meio de cultura. Contudo, a lipofecção de mRNA não foi bem sucedida neste meio, passando, portanto, a ser realizada no meio de cultura RPMI.

Sendo assim, considerando-se que as DCs sem tratamento apresentaram expressão endógena de survivina, observou-se um aumento, tanto em porcentagem de células quanto na intensidade mediana de fluorescência (MFI), após a lipofecção com o mRNA específico da survivina, como pode ser notado pelo deslocamento dos picos nos histogramas da Figura 22. 

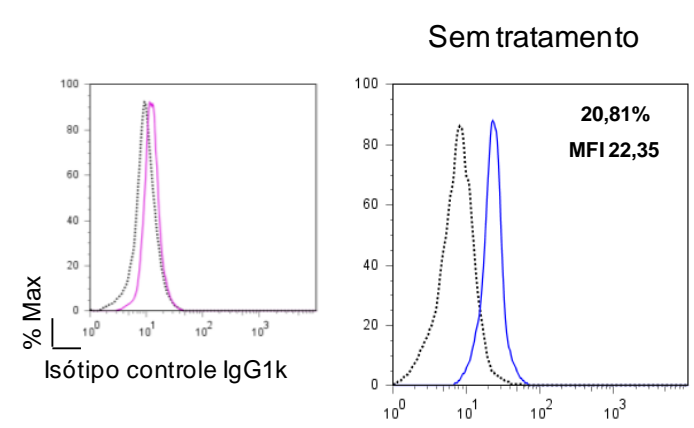

$1 \mu \mathrm{g}$ mRA Survivina $3 \mu \mathrm{L}$ lipofectamina 2000

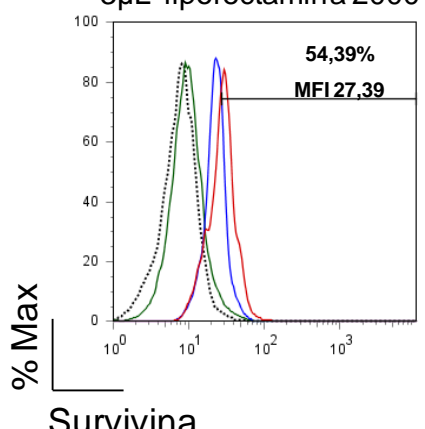

$0,8 \mu \mathrm{g}$ mRNA Survivina $2 \mu \mathrm{L}$ lipofectamina 2000

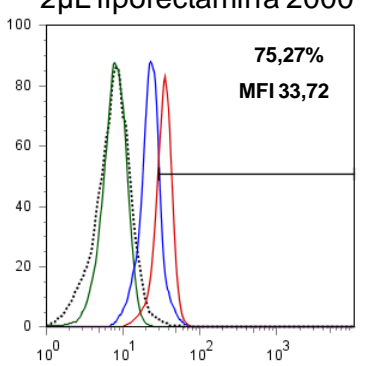

$1,4 \mu \mathrm{g}$ mRNA Survivina $4,2 \mu \mathrm{L}$ lipofectamina 2000

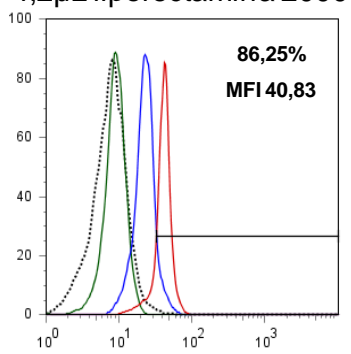

$0,8 \mu \mathrm{g}$ mRNA Survivina

$3,2 \mu \mathrm{L}$ lipofectamina 2000

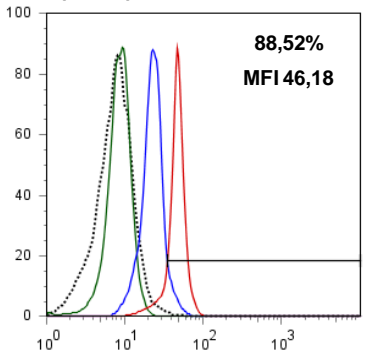

$2 \mu \mathrm{g}$ mRNA Survivina $6 \mu \mathrm{L}$ lipofectamina 2000

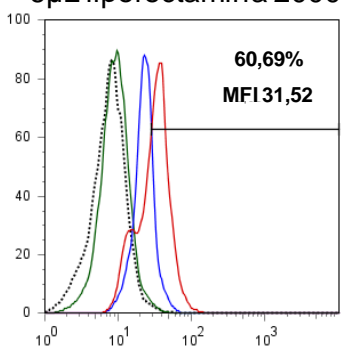

Figura 22 - Histogramas representativos da lipofecção de DCs imaturas, em meio R10, com diferentes concentrações de mRNA da survivina e agente de transfecção. No primeiro gráfico, à esquerda, está representado a marcação do isótipo controle, lgG1k (linha lilás). No gráfico seguinte, está representada a expressão basal de survivina pelas DCs sem tratamento (linha azul). Linhas pontilhadas: DCs sem tratamento; Linhas verdes: DCs tratadas apenas com agente de transfecção; Linhas azuis: expressão basal de survivina nas DCs sem tratamento; Linhas vermelhas: populações específicas de cada tratamento com mRMA e agente de transfecção. Na parte superior de cada gráfico estão os valores da porcentagem de células transfectadas e do MFI-R. Abaixo de cada gráfico estão especificadas as concentrações de mRNA e agente de transfecção utilizadas. As análises foram feitas englobando as células que no gate SSCxFSC eram CD14 e HLA-DR ${ }^{+}$, e nestas células foram delimitados, nos histogramas, gates na intersecção entre as células transfectadas e as células com expressão basal da survivina. Representativo de 4 experimentos.

Diferentes concentrações de RNA/lipossomos foram avaliadas para estabelecer a melhor quantidade a ser utilizada nos experimentos futuros. A média da porcentagem de células transfectadas foi de $35,8 \%( \pm 18,0)$ para $0,8 \mu \mathrm{g}$

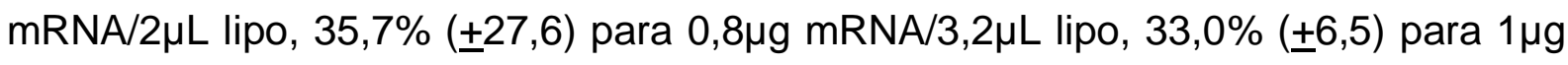
mRNA/3 $\mu \mathrm{L}$ lipo, 41,0\% $( \pm 21,7)$ para $1,4 \mu \mathrm{g}$ mRNA/4,2 $\mu \mathrm{L}$ lipo e $26,1 \%( \pm 18,5)$ para $2 \mu \mathrm{g}$ mRNA/6uL lipo. Observa-se que não houve diferença significativa entre as médias da porcentagem de células positivas para survivina nas diferentes quantidades de RNA/lipossomos testadas (Figura 23). Contudo, nota-se uma grande variação na porcentagem de células transfectadas entre os diferentes experimentos 
realizados. Isto dificulta a escolha da melhor quantidade de RNA/lipossomo para seguir as transfecções.

Com relação ao $\mathrm{MFI}$, os valores encontrados foram normalizados a partir do valor obtido para as DCs sem tratamento e passou a ser chamando de MFI-relativo (MFI-r). O MFI-r também se manteve semelhante para as cinco quantidades de RNA/lipossomos testadas $(1,3 \pm 0,2$ para $0,8 \mu \mathrm{g}$ mRNA/2 $\mu \mathrm{L}$ lipo, $1,4 \pm 0,5$ para $0,8 \mu \mathrm{g}$

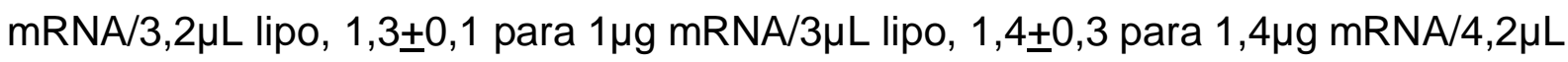
lipo e $1,2 \pm 0,3$ para $2 \mu \mathrm{g}$ mRNA/6 $\mu \mathrm{L}$ lipo). Porém, a variação entre os experimentos foi menor que a observada para a porcentagem de células (Figura 23).

Apesar de não ser a quantidade que mostrou maiores porcentagens de transfecção, a concentração de $1 \mu \mathrm{g}$ de mRNA com $3 \mu \mathrm{L}$ de lipofectamina foi a que apresentou valores mais homogêneos entre os diferentes experimentos tanto em porcentagem de células transfectadas quanto em MFI-r. Portanto, esta foi a concentração de escolha para dar continuidade aos experimentos.
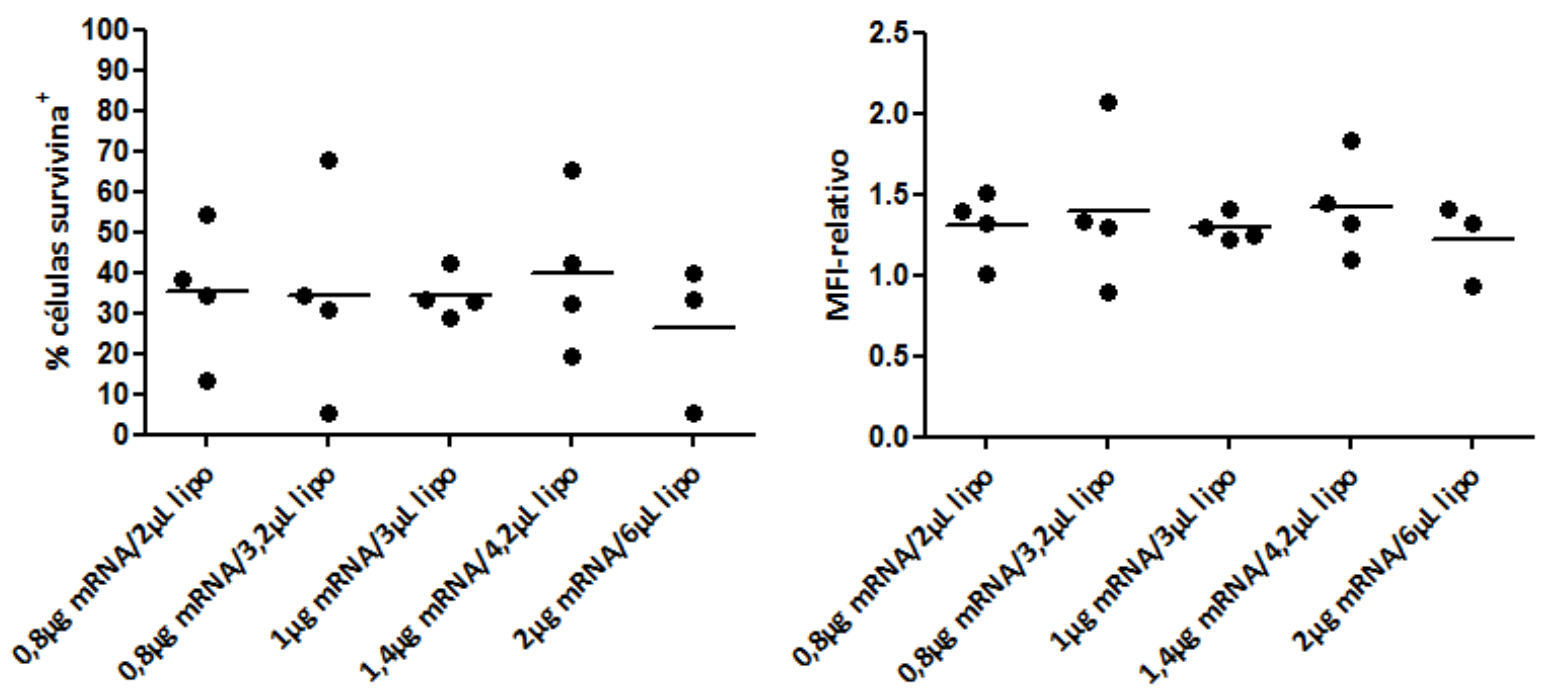

Figura 23 - Comparação das freqüências e dos valores de MFI-relativo entre DCs transfectadas com diferentes concentrações de mRNA da survivina e agente de transfecção. (A) Gráficos de dispersão mostrando as porcentagens de transfecção das DCs imaturas, baseadas na freqüência de células positivas para survivina, após transfecção. (B) Gráficos de dispersão mostrando os valores das intensidades mediana de fluorescência (MFIs) das células transfectadas com mRNA da survivina. Os MFIs foram normalizados a partir dos valores de MFI das DCs sem tratamento (MFI-relativo). Nos dois gráficos, as barras representam a média da porcentagem de células positivas para survivina $(A)$ e a média dos valores de MFI-r (B), após a transfecção. 
$\mathrm{Na}$ análise morfológica, não houve diferença significativa na freqüência de células grandes e granulosas, características de DCs (analisadas no gate de FSC e SSC), entre as DCs tratadas com agente de transfecção ou com os complexos RNA/lipossomos em comparação às células sem tratamento (Figura 24).

Grupo 1

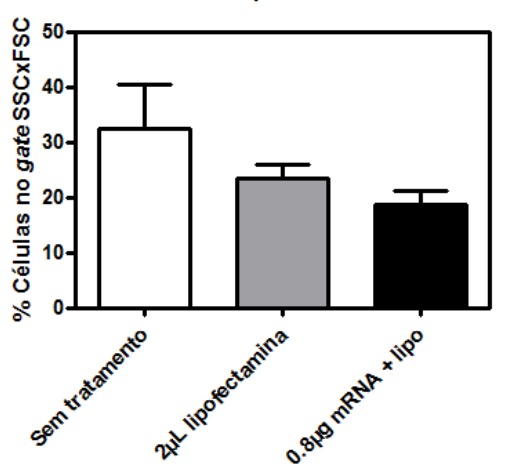

Grupo 2

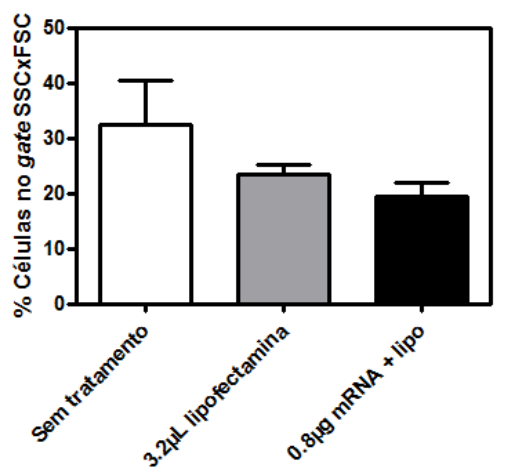

Grupo 3

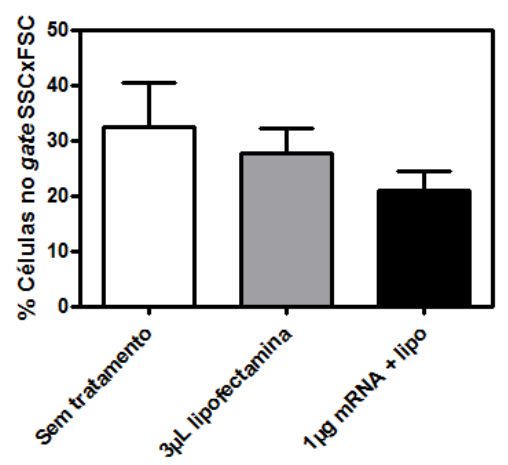

Grupo 4

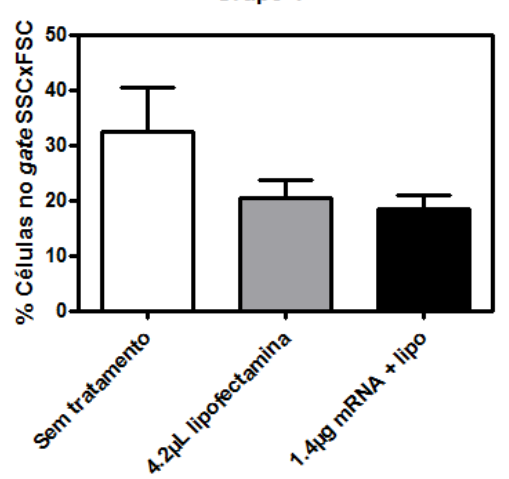

Grupo 5

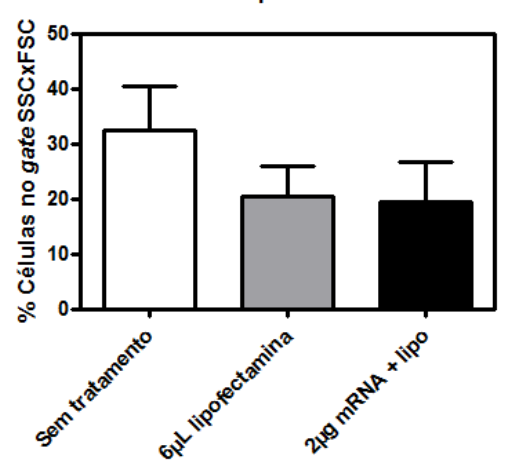

Figura 24 - Comparação das freqüências de células no gate de tamanho (FSC) por granulosidade (SSC) entre DCs sem tratamento, DCs tratadas com agente de transfecção e DCs transfectadas com os complexos mRNA/lipossomos. Gráficos de barras mostrando a porcentagem de células analisadas no gate de tamanho por granulosidade. Foram comparadas as freqüências de células antes do tratamento (barras brancas), após o tratamento com o agente de transfecção lipofectamina 2000 (barras cinza) e após a transfecção com mRNA da survivina (barras pretas). Cada gráfico representa um grupo de tratamento.

Para estabelecer o momento em que o mRNA transfectado passa a ser expresso pelas DCs, e o período de duração desta proteína pós transfecção, resolveu-se estudar a cinética da expressão da survivina pelas DCs. Observa-se que o mRNA transfectado começa aumentar a expressão da survivina 12 horas após a ativação das DCs com coquetel de citocinas, sendo alcançado o pico de expressão dentro de 48 horas (Figura 25B). A porcentagem de células expressando este 
antígeno tumoral aumenta aproximadamente 16\%, 28\% e 43\% em 12, 24 e 48 horas, respectivamente (Figura 25A). Após 1 e 72 horas de transfecção, não se encontra aumento na expressão de survivina nem na freqüência de células postivas (Figura 25A e B).

A

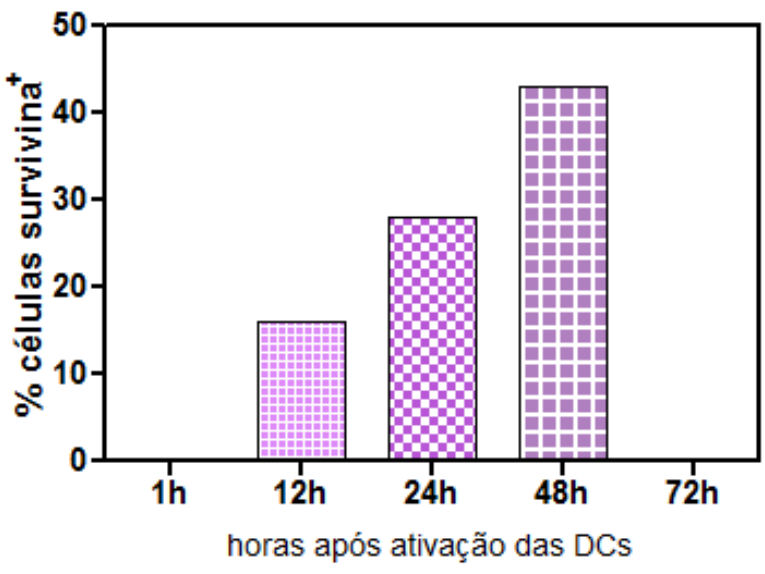

B
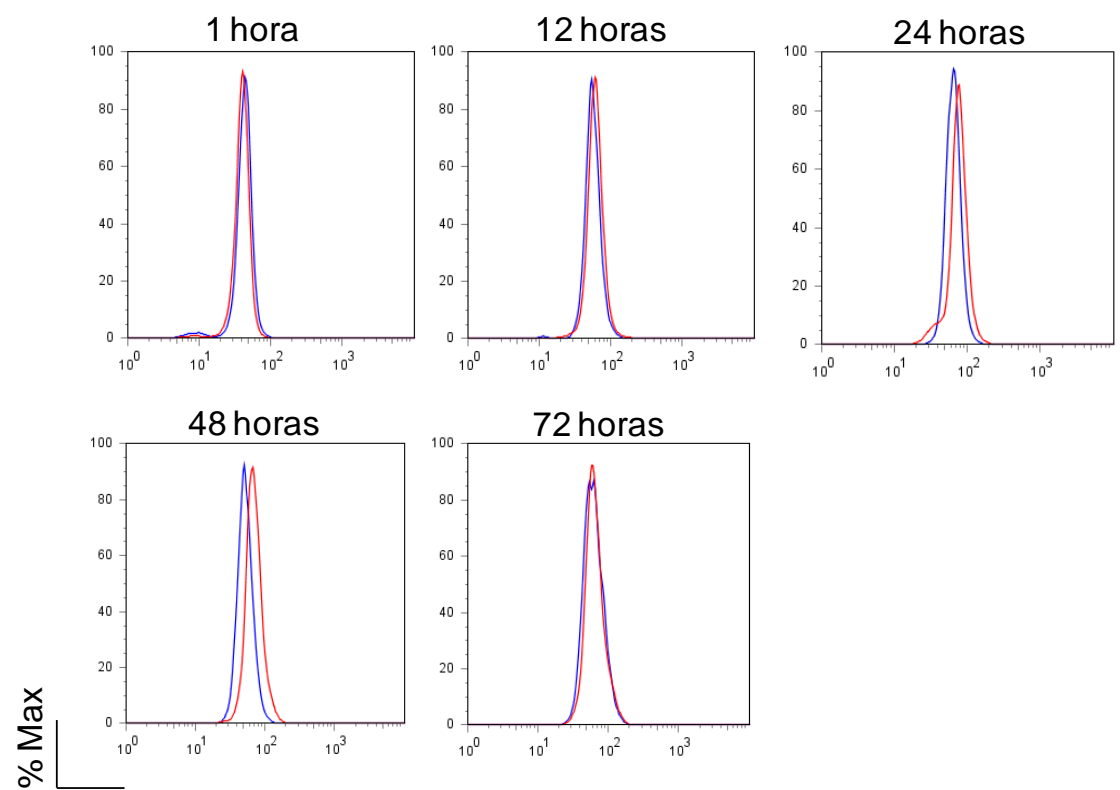

FL1: Survivina

Figura 25 - Cinética da porcentagem de células survivina ${ }^{+}$e da intensidade mediana de fluorescência da survivina após a transfecção das DCs com mRNA. As análises foram feitas englobando as células que no gate SSCxFSC eram CD14 e HLA-DR ${ }^{+}$. As DCs foram transfectadas com $1 \mu \mathrm{g}$ de mRNA da survivina/3$\mu \mathrm{L}$ de lipofectamina 2000. (A) Gráficos mostrando a porcentagem de células survivina ${ }^{+}$após 1, 12, 24, 48 e 72 horas da ativação das DCs transfectadas com coquetel de citocinas. (B) Histogramas mostrando a expressão da survivina nas DCs transfectadas com mRNA após 1, 12, 24, 48 e 72 horas da ativação com coquetel de citocinas. Linhas azuis: expressão basal da survivina pelas DCs. Linhas vermelhas: expressão da survivina após a transfecção com mRNA. 


\subsubsection{Avaliação da viabilidade celular após a transfecção com mRNA}

Uma vez determinada as melhores condições de transfecção, para protocolo aplicado, e observado que não houve mudança significativa na morfologia das células, resolveu-se avaliar a viabilidade das células transfectadas, a fim de observar se este realmente é um bom método para transfectar as DCs.

Com base nos resultados mostrados através da marcação com anexina-V e $\mathrm{PI}$, nota-se que cerca de $60 \%$ das células permanecem viáveis com a metodologia da lipofecção estudada (Figura 26A). O tratamento das DCs apenas com agente de transfecção parece induzir por volta de $28,5 \%$ das células à apoptose tardia, observada pela dupla marcação anexina-V/PI. Já a transfecção com mRNA da survivina não mostrou muita diferença, levando a cerca de $20,6 \%$ das células à apoptose tardia e um pequeno aumento na porcentagem de células necróticas de 7,5 para 11,7\%, comparada ao tratamento com agente de transfecção (Figura 26A). Deve-se considerar também que cerca de $18 \%$ das células morrem devido às manipulações as quais as DCs são submetidas durante a cultura de diferenciação. Isto mostra que, provavelmente o agente de transfecção estaria causando morte em aproximadamente $20 \%$ das células (Figura 26B). 

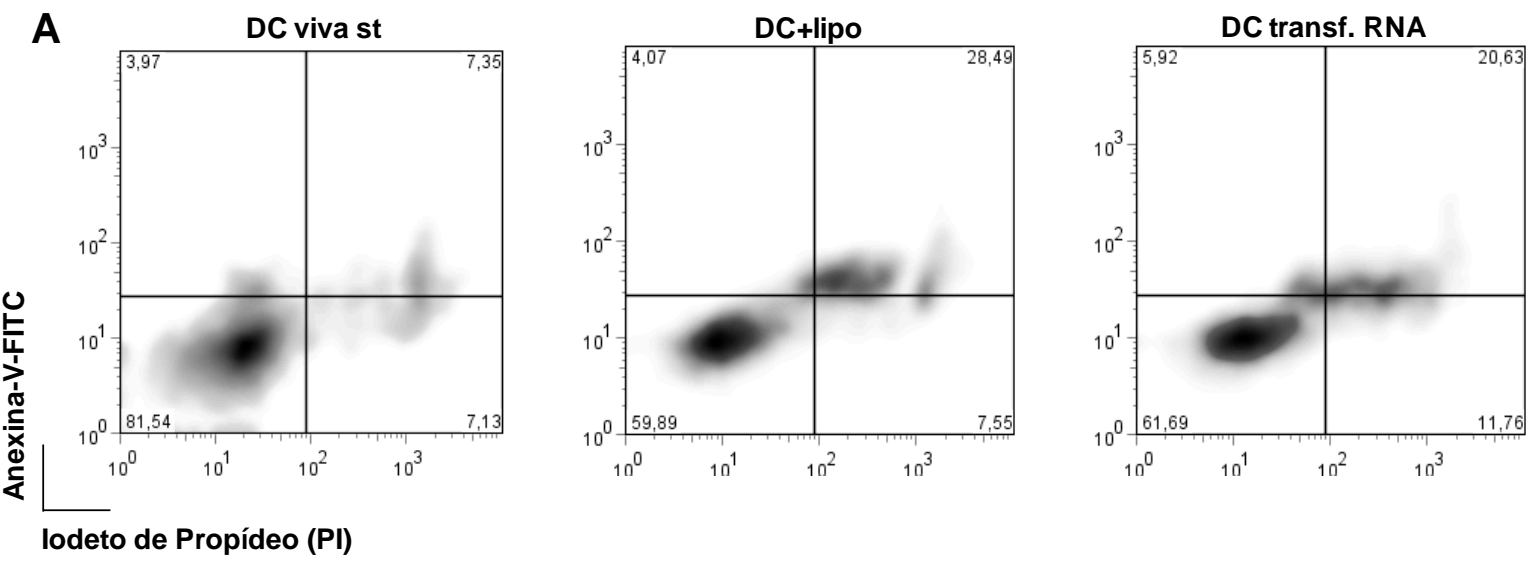

B

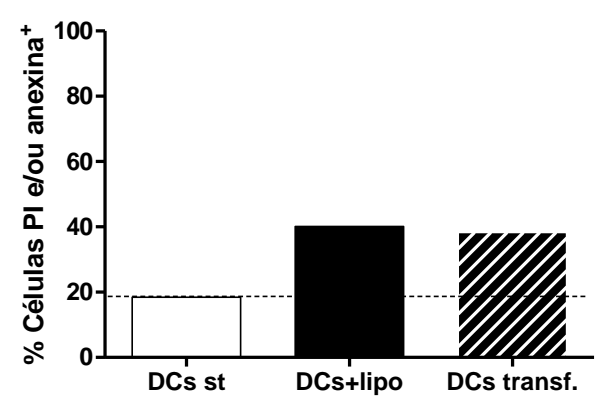

Figura 26 - Gráficos representativos da viabilidade celular após lipofecção com mRNA da survivina. As células foram marcadas com anexina-V e iodeto de propídeo (PI) para avaliar a viabilidade celular. (A): Gráficos de densidade discriminando as porcentagens de células marcadas com PI e anexina. Da esquerda para direita, as DCs controles vivas e sem tratamento, as DCs tratadas apenas com agente de transfecção lipofectamina 2000 e DCs transfectadas com mRNA da survivina. As células $\mathrm{Pl}^{+}$anexina são consideradas necróticas, as células $\mathrm{Pl}^{-}$anexina ${ }^{+}$são consideradas em apoptose inicial, as células $\mathrm{Pl}^{+}$anexina ${ }^{+}$são consideradas em apoptose tardia e as células Pl'anexina são consideradas vivas. (B): Graficos de barras mostrando a porcentagem de células mortas. DCs st: DCs sem tratamento (barras brancas); DCs+lipo: DCs tratadas apenas com agente de transfecção lipofectamina 2000 (barras pretas); DCs transf: DCs transfectadas com mRNA da survivina (barras listradas). Em A e $\mathrm{B}$, as análises foram feitas em gates de tamanho por granulosidade característicos das DCs.

\subsubsection{Avaliação fenotípico-funcional das DCs transfectadas com mRNA}

Para verificar se as DCs tratadas com agente de transfecção ou RNA apresentavam as mesmas características fenotípicas das DCs não submetidas a tratamento algum, estas células foram analisadas quanto à presença das moléculas de superfície HLA-DR, CD14, CD80, CD86, CD40 e CD83, através da citometria de fluxo. 
A comparação do fenótipo de membrana das DCs com e sem tratamento foi realizada considerando-se a população de células grandes e granulosas, característica de DCs, presentes no gate de SSC por FSC (Figura 27). Os resultados desta análise mostraram que o agente de transfecção lipofectamina 2000 ativou as DCs, que apresentaram aumento na freqüência dos marcadores presentes em condições de ativação, CD40 e CD83. Além disso, houve aumento na população de células CD86 ${ }^{\text {hi }}$, e uma pequena diminuição na freqüência de células $C D 14^{+}$, após tratamento com agente de transfecção (Figura 27).

Entretanto, estas alterações encontradas nas DCs após o tratamento com agente de transfecção, só foram observadas quando se considera a população de células duplo-positivas para os marcadores analisados. De maneira geral, não foram encontradas mudanças significativas na porcentagem de células positivas para nenhum dos marcadores avaliados (Figura 28).

A

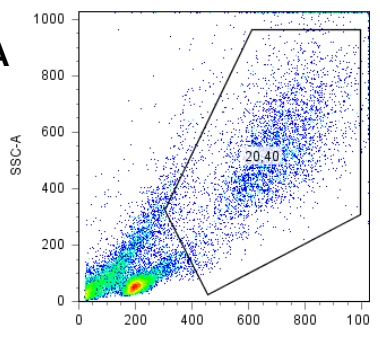

FSC-A

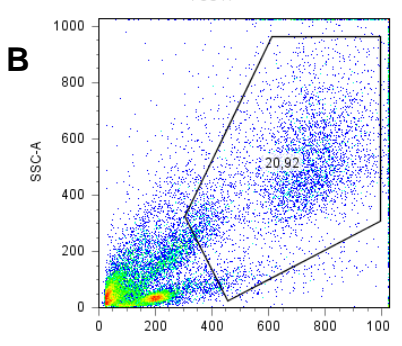

FSC-A

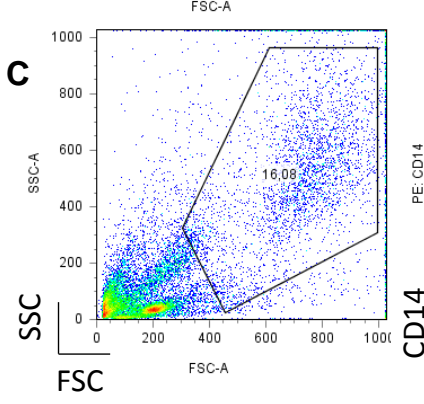

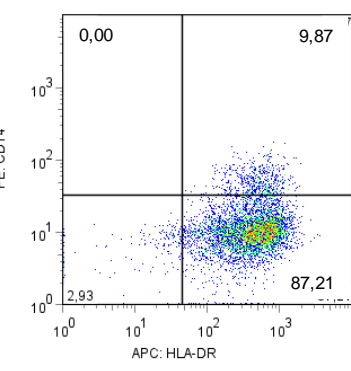
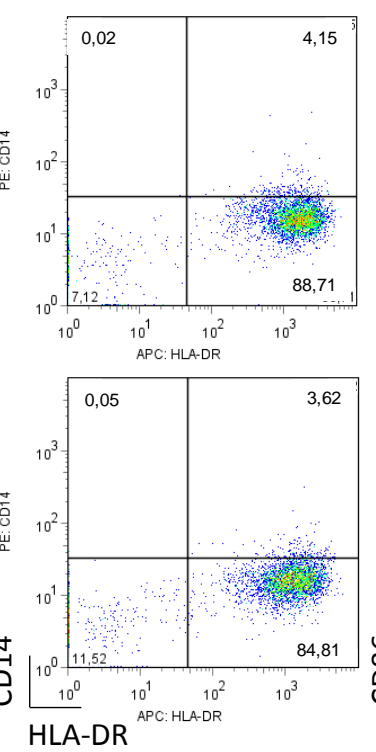
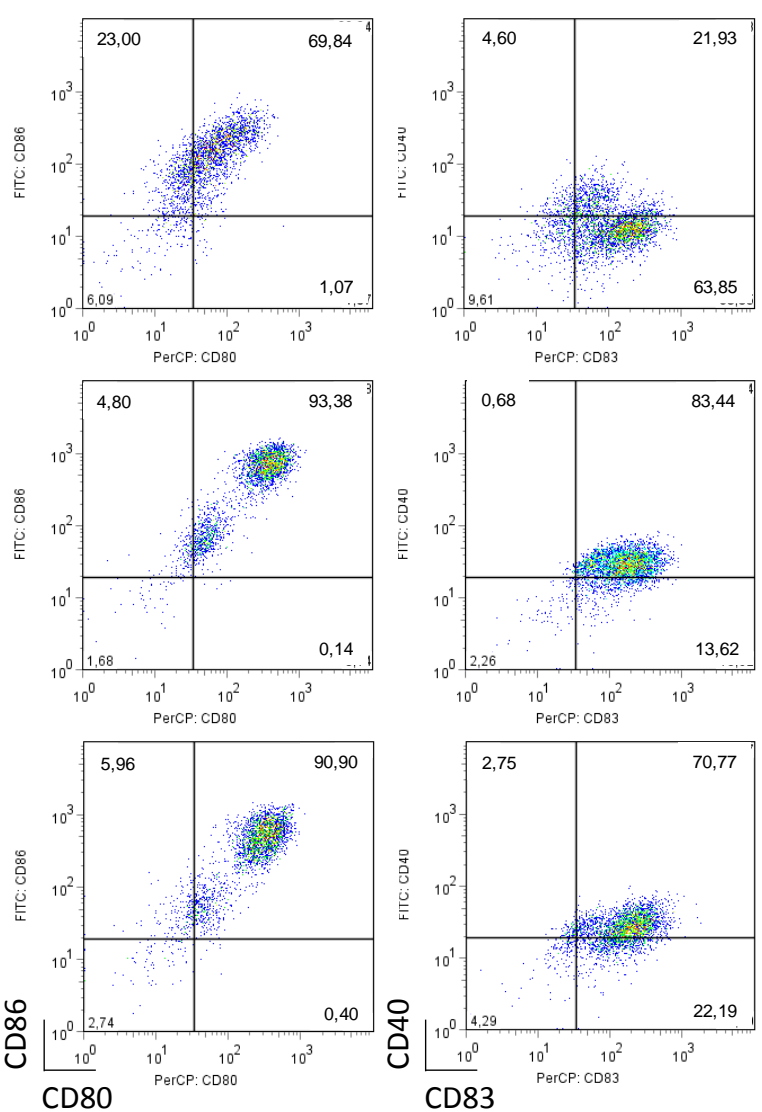

Figura 27 - Comparação fenotípica entre DCs sem tratamento e DCs tratadas com agente de transfecção ou com mRNA da survivina. As análises foram feitas englobando as células que no gate SSCxFSC eram CD14- e HLA-DR ${ }^{+}$. (A) DCs sem tratamento. (B) DCs tratadas com agente de transfecção lipofectamina 2000. (C) DCs transfectadas com mRNA da survivina. Representativo de 2 experimentos independentes. 

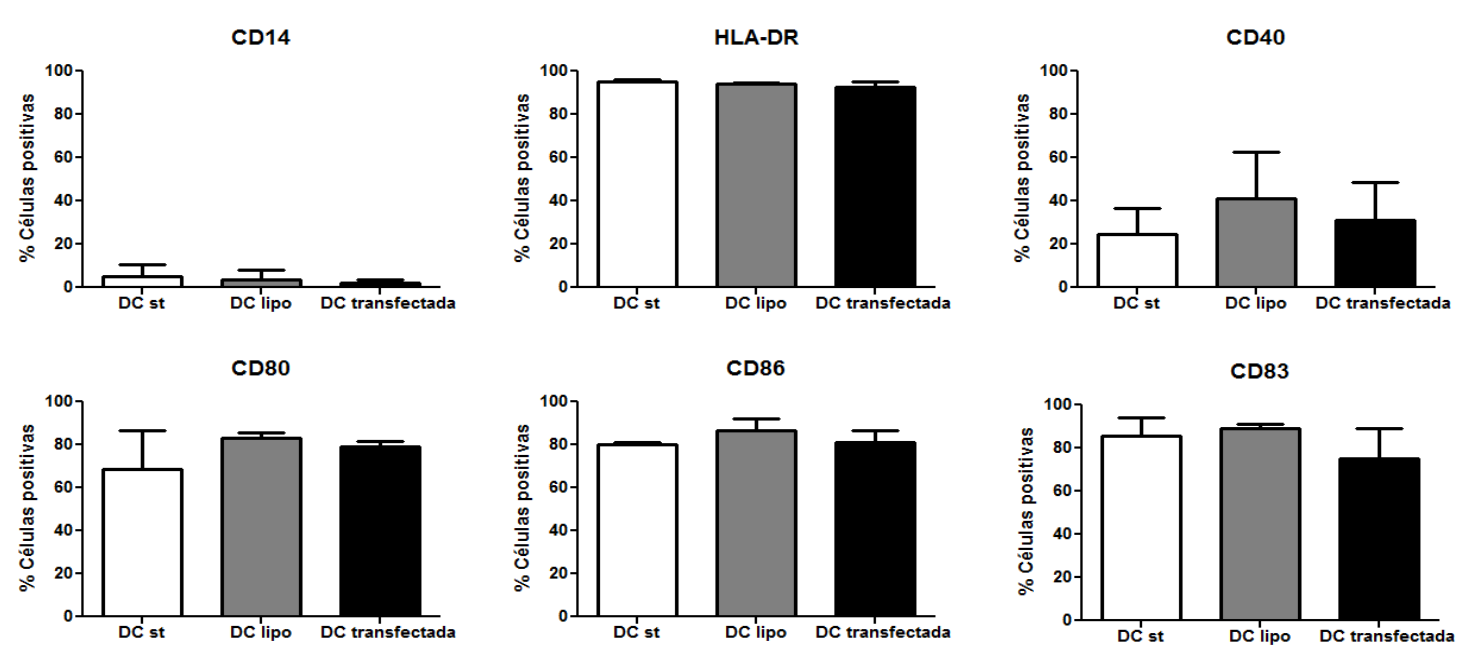

Figura 28 - Gráficos mostrando a freqüência de células expressando os marcadores HLA-DR, CD14, CD80, CD86, CD40 e CD83 em DCs sem tratamento, DCs tratadas com agente de transfecção e DCs transfectadas com mRNA da survivina. As análises foram feitas englobando as células que no gate SSCxFSC eram CD14 e HLA-DR ${ }^{+}$. As barras brancas representam as DCs sem tratamento, as cinzas representam as DCs tratadas apenas com agente de transfecção lipofectamina 2000 e as pretas representam as DCs transfectadas com mRNA da survivina.

Para verificar se ocorre alteração no padrão de citocinas produzidas pelas DCs, após o tratamento com agente de transfecção ou após a transfecção das DCs com mRNA da survivina, avaliou-se no sobrenadante das mesmas a presença de IL12 p70 e IL-10. Apesar de não serem estatisticamente significantes, os resultados para IL-12p70 mostraram que parece haver uma tendência ao aumento de sua produção, das DCs sem tratamento $(4,4 \mathrm{pg} / \mathrm{mL} \pm 2,2)$ para as DCs tratadas com lipofectamina $(5,8 \mathrm{pg} / \mathrm{mL} \pm 3,3)$ e DCs transfectadas $(8,1 \mathrm{pg} / \mathrm{mL} \pm 3,7)$ (Figura 29). Já na análise da concentração de IL-10, observaram-se valores mais elevados do que para IL-12p70, que aumentaram, de forma não significante, com os tratamentos das DCs (DCs sem tratamento 27,8 pg/mL $\pm 21,6$, DCs+lipofectamina 35,7 pg/mL $\pm 29,4$ e DCs transfectadas 79,5 pg/mL $\pm 92,1$ ) (Figura 29). 

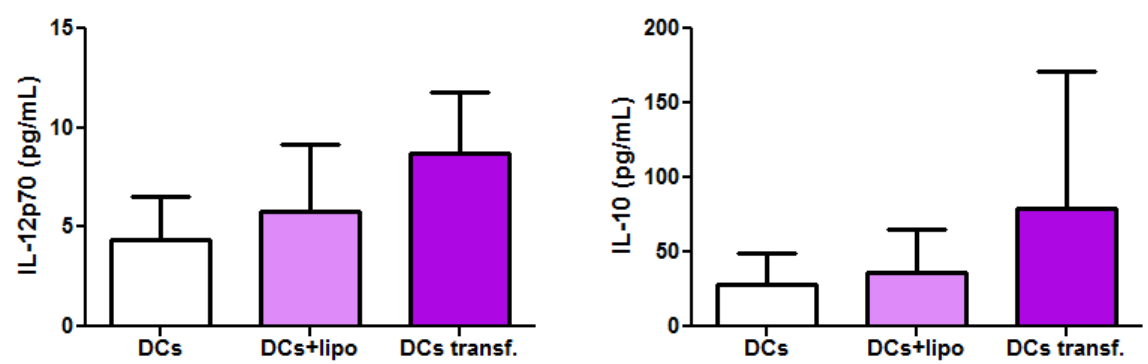

Figura 29 - Concentração de IL-12p70 e IL-10 no sobrenadante da cultura de DCs sem tratamento, DCs tratadas com agente de transfecção e DCs transfectadas com mRNA da survivina. No primeiro gráfico estão às concentrações de IL-12p70 e no segundo gráfico de IL-10. $\mathrm{N}=2$.

A capacidade funcional das DCs transfectadas foi avaliada através de ensaios de estimulação de linfócitos $T$ alogenêicos (MLR) co-cultivados com as DCs transfectadas comparadas às DCs sem tratamento. Nas análises, consideraram-se as células presentes dentro do gate definido como de linfócitos, em tamanho por granulosidade, e verificou-se o índice de divisão celular nesta população, através da diluição do corante CFSE. Para avaliar se houve aumento relativo na estimulação de linfócitos na presença das DCs transfectadas quando comparado com DCs sem tratamento, utilizou-se como referência o índice de estimulação obtido para os linfócitos cultivados com DCs sem tratamento.

Não foram encontradas diferenças na capacidade estimuladora das DCs sem tratamento e transfectadas para linfócitos $\mathrm{T} \mathrm{CD}^{+}$e nem quando se considera a proliferação de linfócitos totais. Contudo, inicialmente, pode-se notar um aumento no índice de estimulação relativa de linfócitos $\mathrm{T} \mathrm{CD}^{+}$, quando as células estimuladoras eram DCs transfectadas com mRNA (1 para 1,34), após uma hora de ativação com coquetel de citonas. Houve um aumento de quase quatro vezes $(1$ para 3,8$)$ no índice de linfócitos T CD4 ${ }^{+}$quando cultivados com DCs transfectadas, após 24 horas de ativação (Figura 30A).

Por outro lado, até então, estes resultados não se repetiram, e não foram mais observadas diferenças entre os índices de estimulação relativa de linfócitos $T$ $\mathrm{CD}^{+}$na presença de DCs transfectadas, com 24 e 48 horas após ativação das DCs. O mesmo foi observado para os índices de proliferação de linfócitos T CD8+ e linfócitos T totais (Figura 30B). 
A
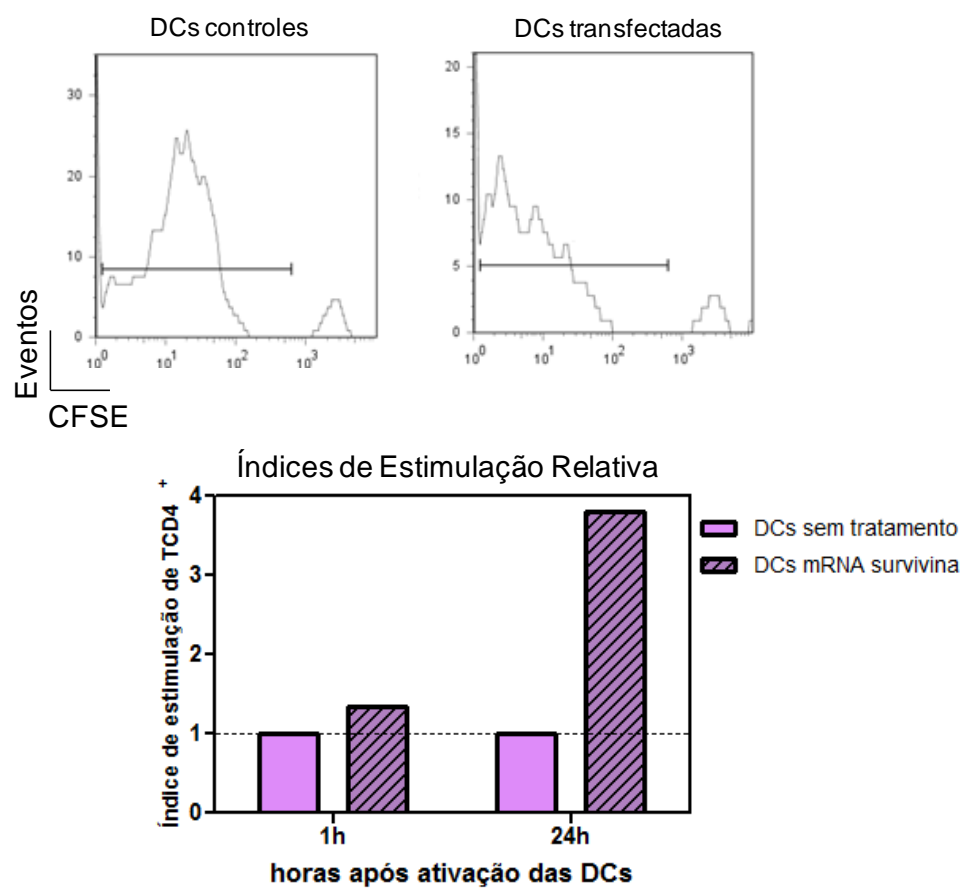

B

LT CD4+

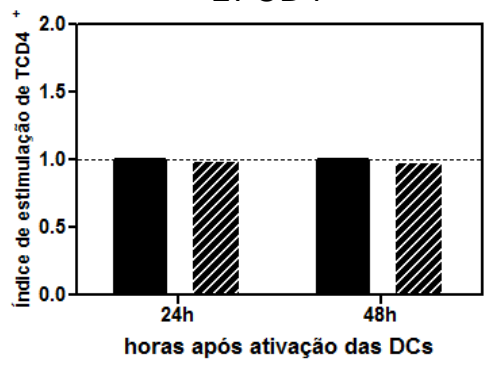

$\mathrm{LTCD}^{+}$

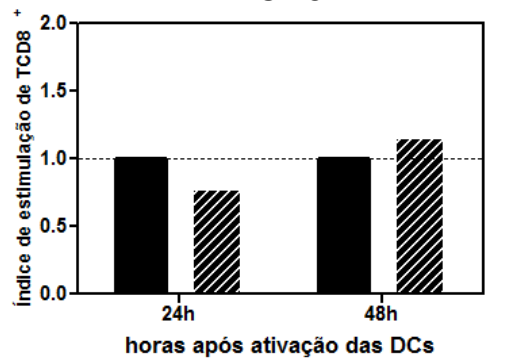

DCs sem tratamento

re DCs mRNA survivina
LT totais

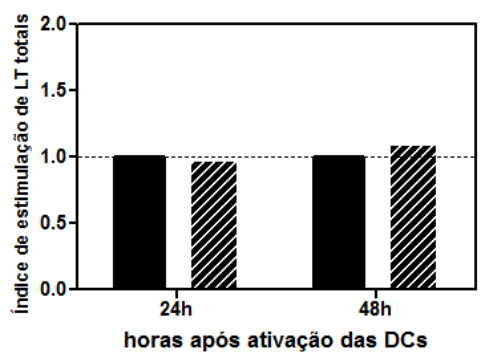

Figura 30 - Capacidade das DCs transfectadas com mRNA da survivina estimularem linfócitos T alogenêicos. (A) Acima: Histogramas ilustrando a diluição do CFSE em linfócitos $T$ $\mathrm{CD}^{+}$mantidos em cultura com DCs transfectadas ou DCs controles, indicando maior diluição quando estes foram cultivados com DCs transfectadas. Abaixo: Índices de estimulação relativa (IE-r) de linfócitos T CD4 ${ }^{+}$, após 1 e 24 horas da ativação das DCs transfectadas, usadas como células estimuladoras, em comparação com DCs controles. (B) IE-r de linfócitos T CD4 $4^{+}, \mathrm{T} \mathrm{CD8}^{+}$e totais mantidos em cultura com DCs controles ou DCs transfectadas após 24 e 48 horas de ativação com coquetel de citocinas. $O$ índice de estimulação relativa (IE-r) foi calculado pelo coeficiente: IE DCs transfectadas/ IE DCs controles. Índice de estimulação (IE) refere-se ao coeficiente: MFI dos linfócitos CFSE ${ }^{+}$ não estimulados/ $\mathrm{MFI}$ dos linfócitos $\mathrm{CFSE}^{+}$experimentais. As análises dos linfócitos totais foram feitas na população de linfócitos dentro do gate de tamanho por granulosidade característico destas células, as análises das células T CD4 e TCD8 foram feitas nas células que dentro do gate de linfócitos eram positivas para estes marcadores. 
No sobrenadante das co-culturas de linfoproliferação foram dosadas as citocinas IFN-gama e IL-10 (Figura 31). Não foram observadas grandes diferenças entre a produção de IL-10 pelos linfócitos cultivados com DCs controles ou DCs transfectadas com mRNA, após 24 e 48 horas da ativação das mesmas (Figura 31A). Já para o IFN-gama, houve maior detecção desta citocina (cerca de $1200 \mathrm{pg} / \mathrm{mL}$ ) do que de IL-10 (cerca de $50 \mathrm{pg} / \mathrm{mL}$ ), nas co-culturas. Entretanto, não houve diferenças na produção de IFN-gama entre linfócitos cultivados com DCs controles e transfectadas, em nenhum dos tempos avaliados (Figura 31B).

A

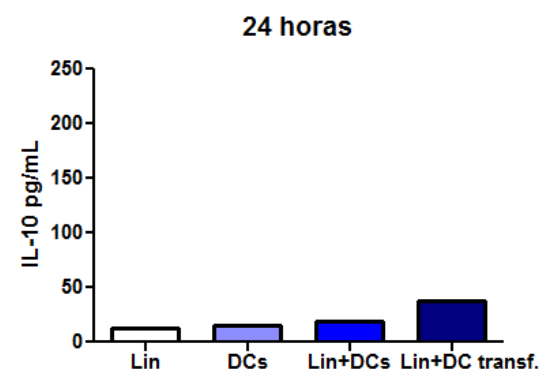

B

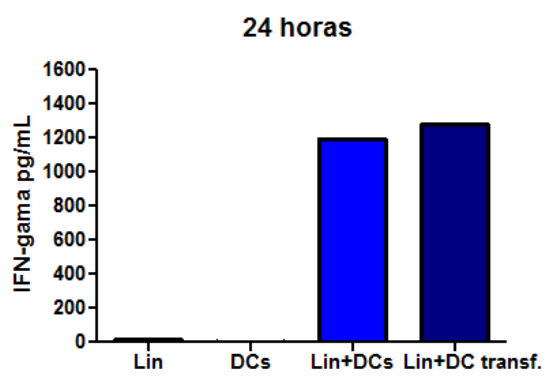

48horas

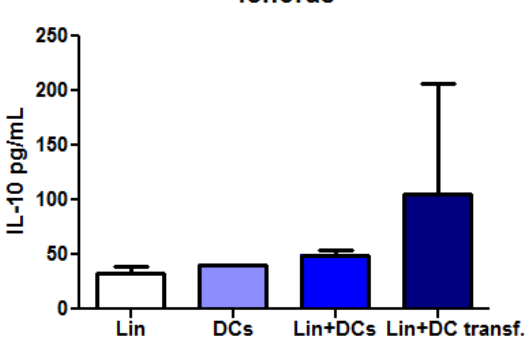

48 horas

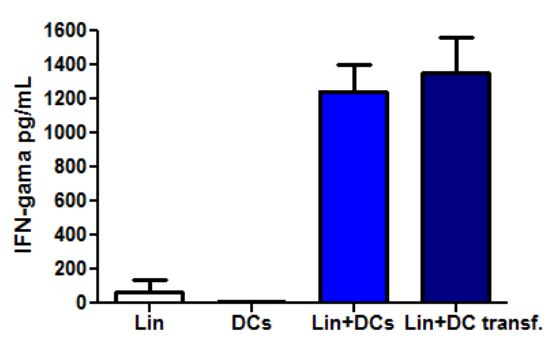

Figura 31 - Concentração de IFN- $\gamma$ e IL-10 no sobrenadante da co-cultura de linfócitos alogenêicos com DCs controles e DCs transfectadas com mRNA da survivina após 24 e 48 horas. Gráficos ilustrando a produção de IL-10 (A) e IFN-gama (B) por linfócitos cultivados, durante 5 dias, com DCs controles e Dcs transfectadas com mRNA da survivina, as quais foram adicionadas à cultura após 24 e 48 horas da ativação com coquetel de citocinas.

\subsection{Obtenção das células leucêmicas}

O próximo passo realizado foi a obtenção das células tumorais, de pacientes com LLC, para, em seguida, extrair o RNA tumoral e aplicar as técnicas de amplificação, transcrição in vitro e transfecção, assim como foi conseguido para o mRNA do antígeno específico survivina. As células leucêmicas foram separadas a 
partir de PBMCs, por esferas magnéticas, em duas etapas seqüenciais. A primeira foi uma seleção positiva para separar as células $C D 19^{+}$, e a segunda foi uma seleção positiva indireta, para obter as células $C D 19^{+} C D 5^{+\cdot}$ Nesta etapa, as células

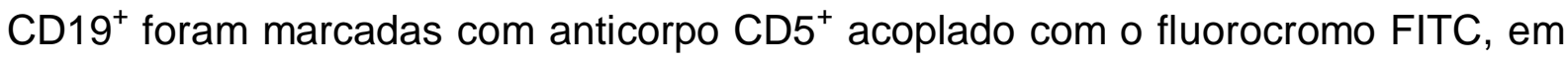
seguida utilizou-se um anticorpo anti-FITC acoplado às esferas magnéticas para, enfim, separar as células duplo-positivas.

Como pode ser observado na Figura 32, houve isolamento das células CD19+ $\mathrm{CD}^{+}$com um grau de pureza em média 62\% (55-70\%). As células duplo-positivas $\left(\mathrm{CD} 19^{+} \mathrm{CD}^{+}\right)$foram analisadas quanto à presença dos marcadores CD20 e CD23, mostrando co-expressão destas moléculas e, desta forma, caracterizando as células leucêmicas.

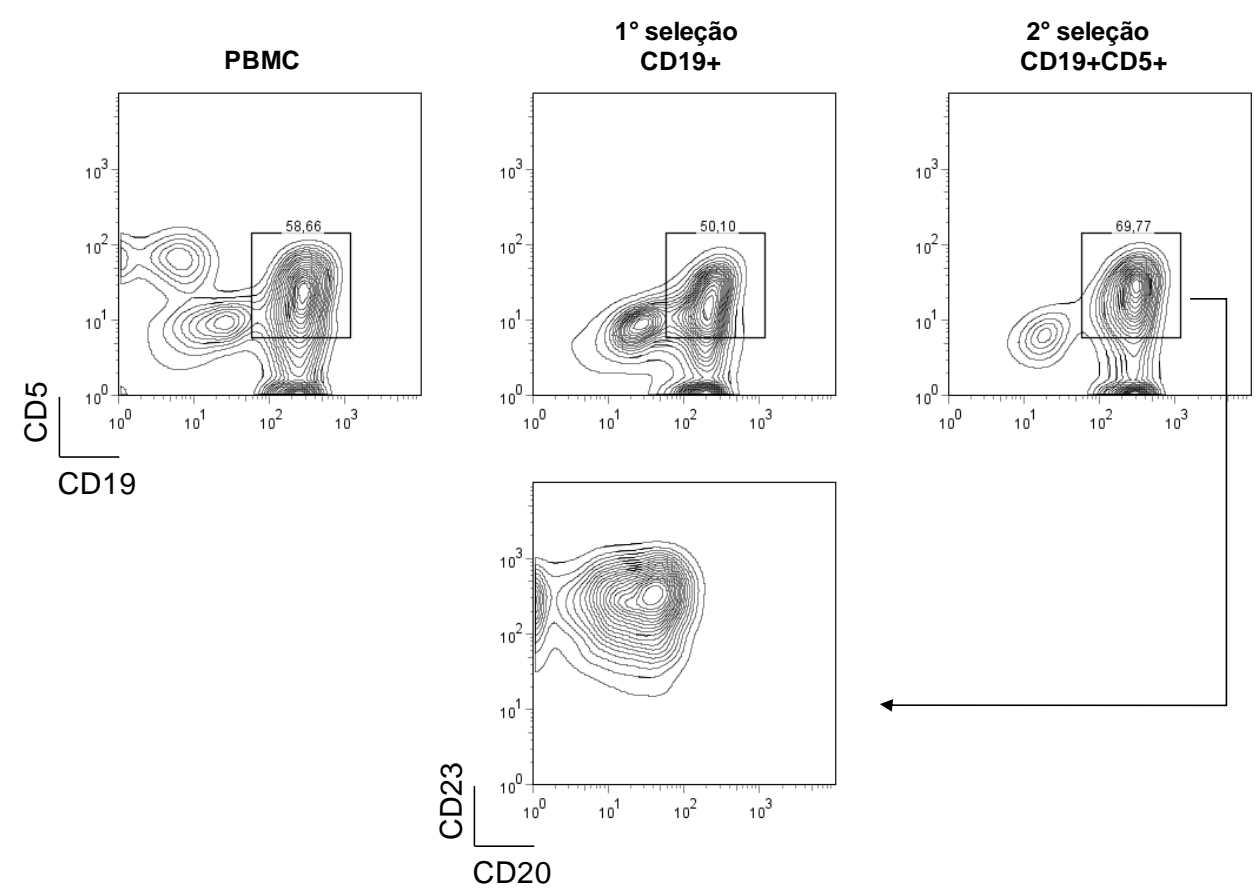

Figura 32 - Separação de células tumorais, obtidas a partir de células do sangue periférico de paciente com LLC, por esferas magnéticas. Gráficos ilustrando a freqüência de

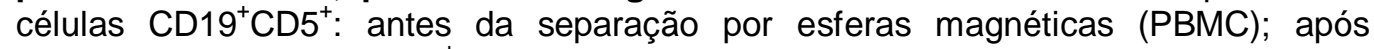
seleção das células $\mathrm{CD}_{19^{+}}$, obtida através da separação por anticorpos anti-CD19 acoplados às esferas magnéticas $\left(1^{\circ}\right.$ seleção $\left(D 19^{+}\right)$, seguida da seleção de células duplo positivas $\mathrm{CD} 19^{+} \mathrm{CD} 5^{+}$, através da separação positiva indireta, em que se marcou as células $\mathrm{CD}_{19^{+}}$com anticorpos anti-CD5-FITC e, em seguida, marcou-se estas células com esferas magnéticas anti-FITC, obtendo as células duplo marcadas $\left(2^{\circ}\right.$ seleção CD19+CD5+). O gráfico abaixo mostra as moléculas de superfície, CD20 e $\mathrm{CD} 23$, analisadas dentro do gate $\mathrm{CD} 19^{+} \mathrm{CD}^{+}$. Análises feitas com gate englobando somente as células com tamanho (FSC) e granulosidade (SSC) característicos de linfócitos. Representativo de 2 experimentos. 


\subsection{Extração, amplificação e transcrição in vitro do RNA tumoral total}

A extração do RNA total de células leucêmicas foi realizada com Trizol ${ }^{\circledR}$ (Invitrogen) e a integridade do produto obtido foi avaliada através de gel de agarose $1 \%$, pela presença das bandas $28 \mathrm{~S}$ e $18 \mathrm{~S}$ do RNA ribossomal (Figura 33). Os extratos de RNA foram quantificados no equipamento nanodrop, conseguindo-se

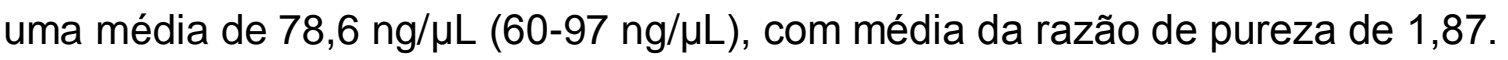

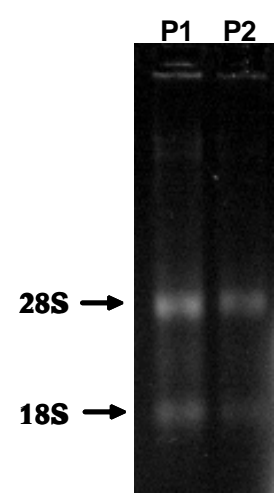

Figura 33 - Eletroforese em gel de agarose dos extratos de RNA tumoral total de células leucêmicas. Fotografia da eletroforese em gel de agarose $1 \%$ de $1 \mu \mathrm{l}$ dos extratos de RNA total do paciente 1 (P1 - canaleta 1) e do paciente 2 (P2 - canaleta 2), evidenciando o padrão de migração dos RNAs das subunidades ribossomais $18 \mathrm{~S}$ e $28 \mathrm{~S}$.

A transcrição reversa é um passo limitante na geração de cDNAs para amplificar todo o mRNA obtido no momento da extração. Para obtenção do cDNA foi utilizado um primer de oligodT modificado que se anelava na cauda poliA do mRNA e uma enzima transcriptase reversa, para síntese da primeira fita de cDNA. A transcriptase reversa adiciona três ou quatro resíduos de $C$ (citosina) na extremidade 5' do cDNA. Essa propriedade é usada para ancorar o primer contendo três resíduos de $\mathrm{G}$, que se anela na repetição de nucleotídeos acrescentados na primeira fita, sendo que este primer continha a sequência do sítio promotor de T7. Isso permite a extensão da segunda fita do cDNA (Figura 34A). 
A

Transcrição reversa do mRNA

Transcrição reversa

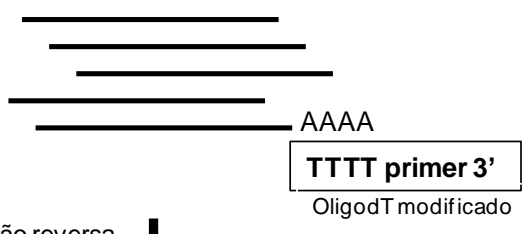

primer T7 GGG

CCC
B

Amplificação do cDNA

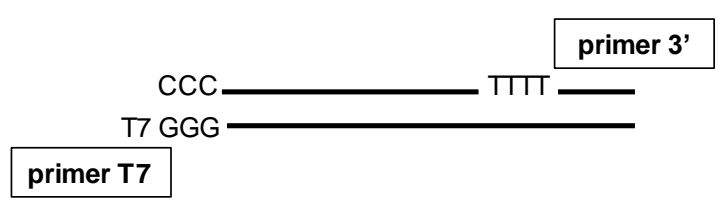

PCR

GGG AAAA

Transcrição reversa

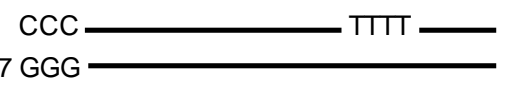

Figura 34 - Esquemas da estratégia de amplificação do mRNA tumoral total. A: O RNA extraído das células leucêmicas foi submetida a transcrição reversa com uma enzima que adiciona três ou quatro resíduos de $\mathrm{C}$ na fita nascente quando chega ao final do molde de RNA. Foi usado como primer um oligonucleotideos contendo resíduos de $\mathrm{T}$ e uma sequencia de 23 nucleotideos necessária para o próximo passo de amplificação (OligodT modificado). Um segundo oligonucleotídeo codificando a sequencia do promotor T7 e 3 resíduos de G (primer T7 GGG) foi usado para extender a extremidade 3' do transcrito. B: Para amplificação do cDNA foi usada uma enzima de alta fidelidade e os primers 3' que anela na região acrescentada pelo oligodT modificado e o primer T7 que anela no promotor T7.

A amplificação do cDNA foi feita com auxílio de dois primers, um que se anelava à parte modificada inserida com o oligodT modificado e o outro se anelava ao sítio do promotor T7 (Figura 34B). Partindo-se do produto de PCR que amplificou o RNA total, foi feita a transcrição in vitro com a enzima T7 RNA polimerase, lembrando-se da adição do cap 5' na porção inicial do mRNA (Figura 35). Obteve-se assim uma grande quantidade de material a partir de uma pequena amostra inicial das células leucêmicas. 


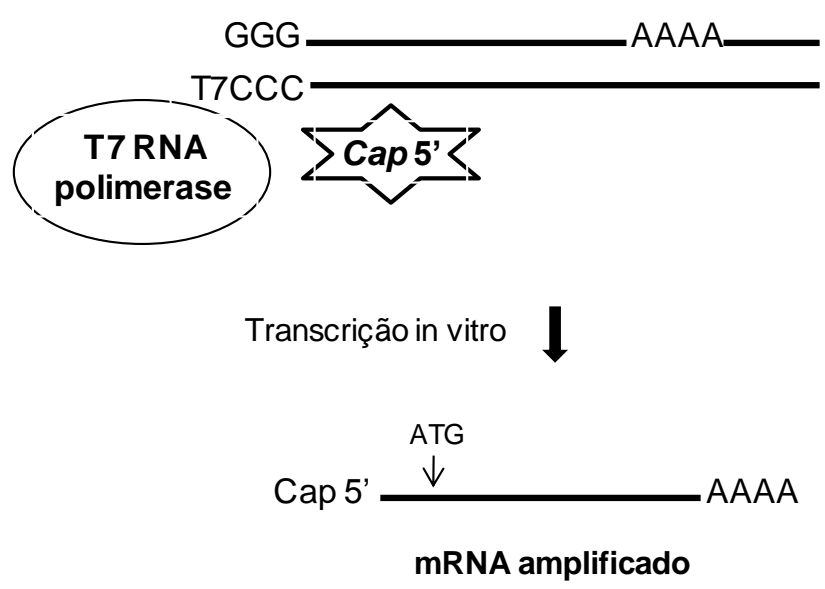

Figura 35 - Esquema da estratégia de transcrição in vitro. A biblioteca de cDNA amplificado foi transcrita em RNA usando a enzima T7 polimerase na presença do análogo do cap 5'.

Ao término da PCR, foi feita nova PCR para amplificação do antigeno tumoral survivina. A amplificação dos antigenos tumorais foi feita a partir do produto de transcrição reversa (cDNA1) e do produto da primeira amplificação do mRNA total (PCR1). A análise em gel de agarose 1\% mostrou que as células leucêmicas expressam o antígeno survivina (91pb) o qual foi mantido após a amplificação do cDNA (Figura 36A).

Para avaliar a funcionalidade da transcrição in vitro, como não é possível a visualização de banda única em gel de agarose, mas sim de uma sombra referente à expressão de pequenas quantidades de vários genes, optou-se por sintetizar fitas de cDNA (cDNA2), a partir deste mRNA transcrito, e novamente amplificá-lo (PCR2). A análise em gel de agarose $1 \%$ mostrou que a partir deste material também foi possível verificar a banda de 91 pb da survivina, mostrando que a expressão do antígeno foi mantida (Figura 36A). Antes de partir para síntese de cDNA a partir do mRNA transcrito in vitro, este foi tratado com DNAse para evitar que os fragmentos da survivina fossem amplificados a partir do cDNA contaminante na amostra de RNA.

Com os produtos de PCR obtidos na primeira amplificação (feita com o RNA total extraído do tumor) e a segunda amplificação (feita com o produto da transcrição in vitro) foram realizadas reações de PCR em tempo real, para verificar a expressão relativa da survivina e RPSA no produto das duas amplificações. Observou-se um 
aumento na expressão de survivina e RPSA no segundo produto de amplificação (PCR2) tendo-se como referência a expressão destes antígenos na primeira amplificação (PCR1) (Figura 36B e C).

A

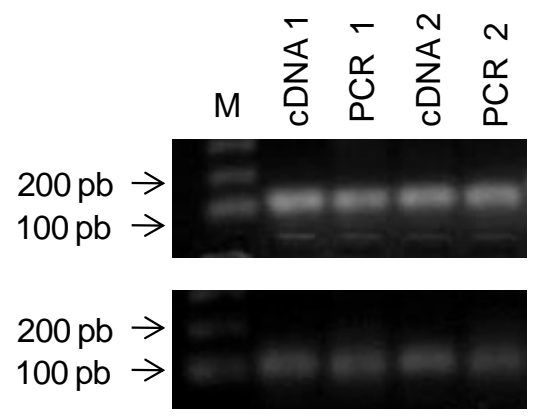

P1

P2

Survivina

B
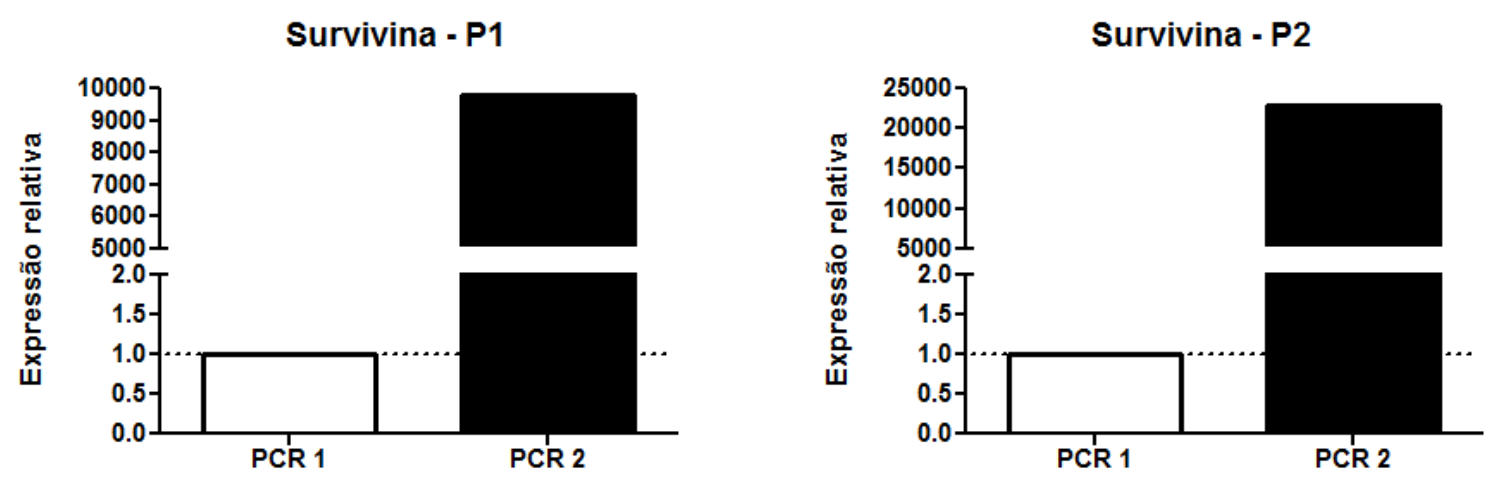

C

RPSA - P1

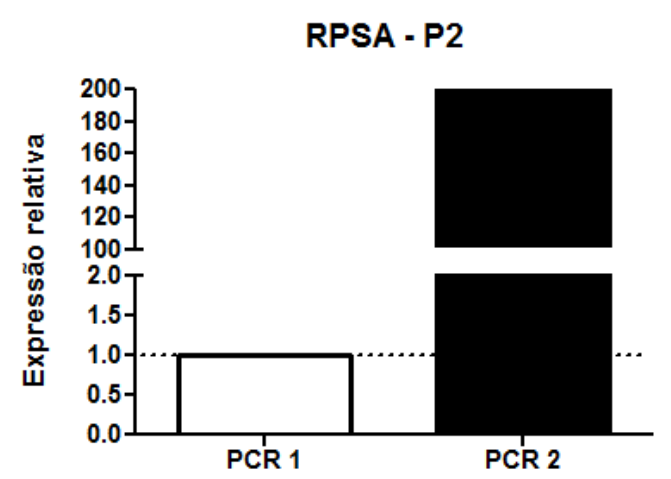

Figura 36 - Expressão dos antígenos tumorais survivina e RPSA antes e após a amplificação do mRNA total obtido de células leucêmicas. A: Fotografia da eletroforese de gel de agarose $1 \%$ mostrando um fragmento de $91 \mathrm{pb}$ correspondente à expressão da survivina pelas células tumorais nos produtos de transcrição reversa e de amplificação do cDNA, realizados a partir do RNA total extraído das células tumorais (cDNA 1 e PCR1) e a partir do mRNA transcrito in vitro (cDNA 2 e PCR 2). M: marcador de peso molecular. B e C: Expressão relativa do mRNA da survivina (B) e da RPSA (C) nas amostras de amplificação do RNA tumoral total (PCR1) e do mRNA transcrito in vitro (PCR2). P1: paciente 1. P2: paciente 2. 
5 DISCUSSÃO 
Neste trabalho avaliaram-se as condições de transfecção de RNA em células dendríticas derivadas de monócitos de doadores saudáveis e sua capacidade em estimular a resposta linfocitária. Ao mesmo tempo, foram estabelecidas as metodologias para amplificação e síntese do RNA de antígenos tumorais específicos, survivina e RPSA, assim como do RNA mensageiro total, contidos nas células tumorais de pacientes com leucemia linfóide crônica.

A amplificação do mRNA contido nas células leucêmicas foi realizada a partir da extração do RNA total, o qual foi submetido a reações de transcrição reversa para obtenção do cDNA, que por sua vez foi amplificado através de primers específicos. A principal característica desta técnica é que o primer 5' usado para amplificação do cDNA codifica o promotor T7. Como resultado, o cDNA amplificado serve de molde para transcrição in vitro do RNA, que deste modo pode ser sintetizado ilimitadamente. Neste aspecto, é interessante notar que a grande vantagem de transfectar as DCs com RNA em vez do cDNA amplificado é pelo fato de que este último necessitaria da clonagem de uma biblioteca de cDNA em vetores de expressão, para providenciar um promotor eucariótico, o que seria um procedimento inviável no caso da aplicação ao material genético de cada paciente.

A literatura mostra que não há diferenças na indução de resposta de CTLs específicos a determinados antígenos tumorais, quando as células estimuladoras são DCs transfectadas com RNA nativo ou com mRNA amplificado (BOCZKOWSKI et al., 2000; BERGANT et al., 2006; NI et al., 2008). Embora neste trabalho não tenham sido realizados ensaios de transfecção com mRNA total amplificado, mostramos ser possível a amplificação in vitro do RNA mensageiro isolado de células leucêmicas sem perda da expressão dos antígenos tumorais, survivina e RPSA, avaliados. Isto foi confirmado através da avaliação dos transcritos de survivina e RPSA no RNA nativo e no RNA amplificado. De maneira geral, os dados apresentados neste trabalho foram consistentes com os resultados do grupo de Gilboa, pioneiros na descrição da técnica de amplificação do RNA para uso em vacinas terapêuticas (BOCZKOWSKI et al., 2000; GILBOA e VIEWEG, 2004).

As padronizações da reação de transcrição in vitro foram realizadas com os antígenos tumorais survivina e RPSA. Os vetores plamideais usados como molde nas reações de trancrição eram ideais, pois continham a sequência do promotor SP6, e dessa forma, encontrando-se as condições adequadas de reação, foi possível sintetizar o RNA mensageiro destes antígenos com adição do cap 5'. A 
adição do análogo do cap à 5' ao RNA transcrito é essencial para que este RNA seja funcional e possa ser traduzido pelas células (KOWALSKA et al., 2008). O cap será incorporado à fita de RNA como um nucleotídeos 5'. Contudo, deve-se considerar também, durante as padronizações da reação de transcrição, que o nucleotídeo GTP compete com o cap na ligação inicial da fita (BOCZKOWSKI e NAIR, 2010; KUHN et al., 2010). Sendo assim, foi imprescindível ajustar a concentração de GTP nas reações.

Para a transfectar as DCs, algumas padronizações foram necessárias, iniciando-se esta etapa pela transfecção das células com DNA, através do emprego do vetor plasmideal pLV-EGFP. O gene EGFP foi escolhido pela facilidade em detectar as células transfectadas por meio da expressão da EGFP, uma proteína fluorescente sem expressão endógena. A princípio, a funcionalidade da construção pLV-EGFP foi confirmada pela eficiente transfecção em células de linhagem. A partir daí, foram testados dois métodos de transfecção em DCs, lipofecção e eletroporação.

A técnica de eletroporação foi escolhida como método de transfecção inicial. Foram testados dois diferentes protocolos, um deles utilizando solução de glicose a $5 \%$ e o outro o meio RPMI para eletroporar as células. Dentre os vários parâmetros avaliados, observaram-se melhores resultados com $1 \mu \mathrm{g}$ de DNA em 0,5 mL de glicose a 5\%. Apesar da boa eficiência de transfecção obtida com estes parâmetros, observou-se, de maneira geral para todos os parâmetros testados, uma grande mudança no aspecto morfológico das células submetidas a este método, que se apresentaram menores e bastante granulosas. O que parece acontecer, é que após a passagem da corrente elétrica, as células morrem. Tal suposição foi confirmada pela avaliação da citotoxicidade celular, através da marcação com anexina-V e $\mathrm{PI}$, que apontou mortalidade de mais de 50\% das células. Com relação a esta citoxicidade encontrada, pode-se afirmar que não foi causada pela presença do DNA e sim da aplicação do choque elétrico, uma vez que as células que receberam corrente elétrica sem DNA também apresentaram alta porcentagem de mortalidade. Isso, em parte, pode ser provocado pela dirupção da membrana e formação de poros que permitem a passagem do conteúdo intracelular, principalmente, de íons. Em teoria, o uso da solução de relaxamento (solução salina tamponada), após a aplicação do choque elétrico, serviria para estabilizar essa perda de sais pelas células. No entanto, nossos resultados sugerem que isto não foi suficiente para 
impedir a morte celular. Estes fatos mencionados são, contudo, apenas suposições para explicar a morte celular observada, já que não foram encontrados na literatura relatos sobre esse tipo de problema com o qual nos deparamos.

Recentemente, a eletroporação vem se destacando como um dos melhores métodos para transportar ácidos nucléicos às DCs (MU et al., 2003; BONEHILL et al., 2009; SCHUURHUIS et al., 2009; WANG et al., 2009; BOCZKOWSKI e NAIR, 2010). Entretanto, nossos resultados não corroboraram os dados da literatura, que mostram este método superior à transfecção passiva e à lipofecção, tanto em eficiência de transfecção quanto na viabilidade celular (LANDI et al., 2007; WANG et al., 2009; BOCZKOWSKI e NAIR, 2010).

Seria possível que o tipo de ácido nucléico usado nos experimentos possa estar relacionado com nossas dificuldades em estabelecer uma eletroporação totalmente eficaz como mostra a literatura. De acordo com Van Tendeloo et al. (2001), a eletroporação é mais eficiente no caso do transporte de mRNA às DCs do que no transporte de DNA plasmideal. Além do mais outros fatores podem ter influenciado nos resultados obtidos como a voltagem escolhida, volume final na cubeta, tipo de cubeta, dentre outros, necessitando melhorar as condições para realização deste método.

Por outro lado, alguns trabalhos mostram que a lipofecção é tão eficiente quanto a eletroporação para transferir mRNA às DCs (GAO et al., 2007; NI et al., 2008). A técnica de lipofecção é comumente usada em terapia gênica para transfectar DCs, pelas suas formulações lipídicas carregadas positivamente capazes de transportar moléculas com carga negativa (BOCZKOWSKI et al., 2000; GILBOA, 2004; GILBOA e VIEWEG, 2004). Apesar de não serem todas as formulações lipídicas compatíveis com uso clínico, este é um método bastante eficiente. Sabe-se que a eficiência do transporte do DNA para dentro do citoplasma é dependente da proporção de carga positiva e negativa entre lipídeo e DNA e pela composição do meio (HOFLAND; SHEPHARD; SULLIVAN, 1996). Por isso, para os ensaios de lipofecção foram usadas diferentes concentrações de pLV-EGFP e lipossomos, além dos meios de cultura AIM-V e R10.

A lipofecção só se mostrou eficiente quando realizada no meio de cultura AIM-V, para todas as concentrações de DNA/lipossomos avaliadas. No entanto, observou-se uma diminuição na porcentagem de células com tamanho e granulosidade característicos de DCs, dentro da região de análise. Tal fenômeno 
não foi observado no caso das DCs transfectadas em meio R10. Uma possível hipótese para este acontecimento seria algum tipo de sinalização causada pelo DNA que entrou nas células. Os experimentos de lipofecção no R10, onde não foram encontradas mudanças morfológicas nas células, podem ser explicados pela transfecção ineficiente do DNA, que por consequência não causou nenhum tipo de alteração. Recentes estudos de transfecção em macrófagos mostram que a liberação de DNA no citoplasma pode ser reconhecida pelo receptor intracelular AIM-2 (absent in melanoma 2), com montagem de um inflamassoma que leva a ativação de caspase-1 e conseqüente liberação de IL1- $\beta$ e IL-18. Em paralelo a formação do inflamassoma AIM-2 ocorre ativação do NF-KB (fator nuclear KB) e indução de um tipo específico de morte celular chamado de piroptose (HORNUNG e LATZ, 2010). Talvez este mecanismo seja coerente com o que aconteceu às células transfectadas neste estudo.

Dentro da população de células grandes e granulosas transfectadas com pLVEGFP, no meio AIM-V, foi detectada a presença nítida de duas populações de células CD86 ${ }^{+}$. Uma delas tinha alta expressão de CD86 (CD86 ${ }^{\text {high }}$ ) enquanto a outra tinha baixa expressão desta molécula $\left(C D 86^{\text {low }}\right)$. Após analisar estas duas subpopulações, notou-se que apenas a população CD86 ${ }^{\text {low }}$ havia sido transfectada, mostrando expressão da proteína EGFP. Isto é coerente com dados da literatura que mostram maior eficiência de transfecção nas DCs imaturas, o que se relaciona ao fato das iDCs estarem capturando antígenos do meio, enquanto as células que já amadureceram diminuem essa atividade, especializando-se em apresentar antígenos (BANCHEREAU et al., 2000; WANG et al., 2009).

Estabelecidas as condições e o método de transfecção, através do uso do DNA, partiu-se para a transfecção de mRNA nas DCs, que é o real objetivo deste trabalho. Primeiramente, a tentativa de usar o mRNA do EGFP, como um controle da funcionalidade da técnica de transcrição in vitro e transfecção, não foi bem sucedida. Uma possível explicação poderia ser porque foi utilizado apenas a região codificante (CDS) do gene EGFP para a clonagem no vetor plasmídeal pGEM-Teasy. Com isso, o mRNA ficou "nu", sem as regiões não traduzidas (UTRs) e parte da cauda poliA. Este incidente pode ter facilitado a degradação do mRNA no ensaio de transfecção feito em linhagem celular (dados não mostrados), já que este ácido nucléico possui meia vida curta dentro das células (KUHN et al., 2010). Portanto, o mRNA da survivina, obtida a partir de clones de cDNA com todos os requisitos necessários 
para transcrição in vitro e transfecção, foi transfectado em DCs imaturas com diferentes concentrações de RNA/lipossomos, seguindo uma razão de 1:3, que seriam as melhores condições aqui encontradas para transfecção com pLV-EGFP.

É importante destacar que, há controvérsias entre os autores, quanto ao relato de expressão endógena da survivina nas DCs. Por um lado, alguns trabalhos que usam mRNA da survivina para transfectar DCs não a detectaram antes da transfecção (BROSSART et al., 2000; ZEIS et al., 2003). Já outros trabalhos mostram que algumas isoformas da survivina têm sido encontradas em células mononucleares do sangue periférico e granulócitos (LOPES et al., 2005). Aqui, foi encontrado expressão endógena de survivina, e os dados de transfecção das DCs com seu mRNA foram avaliados com relação ao aumento da porcentagem de células survivina ${ }^{+}$ou ao aumento da expressão desta proteína nas DCs.

Com os resultados de transfecção com mRNA, pôde-se observar que não houve diferença na eficiência de transfecção entre as diferentes concentrações de RNA/lipossomos testadas, nem em porcentagem de células positivas para survivina, tão pouco no MFI-r. Contudo, houve uma grande variação na porcentagem de células survivina ${ }^{+}$entre diferentes experimentos realizados para uma mesma concentração de RNA. Isto pode ser reflexo da heterogeneidade das DCs diferenciadas in vitro (NAIK, 2008). Não somente neste trabalho, mas também em outros de nosso laboratório, é observada uma variação na expressão dos marcadores de superfície que caracterizam as DCs, dependendo, por exemplo, do doador e meio de cultura utilizado.

No caso da transfecção de DCs com mRNA, não foram observadas mudanças na proporção de células grandes e granulosas, como visto após a lipofecção com DNA. Para comprovar estes achados, realizou-se a marcação das células com PI e anexina-V antes e após a lipofecção do mRNA, e foi visto que $60 \%$ das células eram viáveis, sendo o agente de transfecção responsável por $20 \%$ da toxicidade observada. Assim, a transfecção de DCs com mRNA mostrou ser mais eficiente e menos tóxica, em comparação com a transfecção de DNA, o que é consistente com Melhem et al. (2008).

Levando-se em conta que o RNA é muito lábil e tem um tempo de meia-vida curto comparado ao DNA, consideramos importante estudar a cinética de expressão protéica após a transfecção das células, para escolher o melhor momento a serem realizados os ensaios funcionais. Na literatura, estudos mostram que o RNA já pode 
ser detectado três horas após a transfecção, geralmente atingindo um pico máximo de expressão do antígeno transfectado após 24 horas, seguido por um declínio em função do tempo (VAN TENDELOO et al., 2001; PONSAERTS et al., 2002). Nos ensaios deste trabalho, avaliou-se a expressão da survivina nos intervalos de 1, 12, 24, 48 e 72 horas após a transfecção das DCs com mRNA da mesma. O pico de expressão da survivina foi 48 horas após a transfecção, o que vai de acordo com a literatura que mostra a expressão ótima de proteínas dentro de uma janela de tempo entre 12 e 48 horas (BONEHILL et al., 2004; UENO et al., 2004).

Van Tendeloo et al. (2001) mostraram que era possível detectar a expressão da proteína EGFP até cinco dias após a transfecção das DCs com mRNA da mesma. Já Gao et al. (2007) mostraram que a transfecção de DCs com mRNA total extraído de células de linhagem tumoral passava a expressar uma proteína conhecida quatro horas após a transfecção, com máxima expressão em 8 horas. Essas diferenças observadas podem ser reflexo dos diferentes tempos de meia vida de cada proteína e, além disso, a rápida eliminação dos RNAs deve ser resultante da degradação por RNAses intracelulares.

Os ensaios funcionais de MLR para avaliar a capacidade estimuladora das DCs transfectadas com mRNA da survivina foram feitos com as DCs retiradas da cultura nos intervalos de tempo de 1, 24 e 48 horas após sua transfecção. Observamos uma maior capacidade das DCs transfectas em estimular a população de linfócitos T CD4 ${ }^{+}$em comparação às DCs controles, quando estas células eram removidas da cultura 1 e 24 horas após a transfecção. No entanto, estes resultados não foram reproduzidos.

A estimulação dos linfócitos pelas DCs transfectadas poderia ser efeito do reconhecimento do RNA por receptores do tipo Toll pelas DCs, mais especificamente TLR-8. Este receptor está presente em vesiculas endossomicas e é capaz de reconhecer RNA fita simples, induzindo as DCs a produzirem IFN tipo I e citocinas pro-inflamatórias e reguladoras (HEIL et al., 2004). Dessa forma, o RNA transfectado poderia modular as DCs, via Toll, aumentando a expressão de moléculas codificadas pelo MHCII e moléculas co-estimuladoras, assim induzindo uma maior proliferação.

Vários trabalhos mostram que o RNA transfectado nas DCs é traduzido em proteínas que passam a ser expressas na superfície das células transfectadas. Acredita-se que a entrada dos complexos de transfecção RNA/lipossomos nas 
células aconteça por endocitose. Desde modo, é necessário que este RNA seja liberado das vesículas endocíticas para ser traduzido no citoplasma das células. Há relatos mostrando que as diferenças de cargas entre as membranas endossomais aniônicas e os lipossomos catiônicos desestabilizam as membranas do endossomo e facilitam o escape do RNA para o citoplasma. Além disso, o pH baixo presente no interior dos lisossomos também contribui para a dissociação do RNA de seus carregadores (OLEJNICZAK; GALKA; KRZYZOSIAK, 2010). Uma vez no citoplasma das células, é possível que este RNA seja traduzido e a proteína formada pode ser expressa na superfície ou intracelularmente, como no caso da survivina. Caso a proteína fique no citoplasma pode ser processada em proteassomo, participando da apresentação a linfócitos $\mathrm{T} \mathrm{CD} 8^{+}$via moléculas codificadas pelo $\mathrm{MHCl}$. De fato, a maioria dos trabalhos de transfecção com mRNA mostra que há indução, principalmente, de linfócitos T CD8 pelas DCs transfectadas (ZEIS et al., 2003; NI et al., 2008; WANG et al., 2009).

Por outro lado, estudos in vitro envolvendo DCs transfectadas com mRNA mostraram que há indução de resposta de linfócitos T CD4 e CD8 (MULLER et al., 2004). Estes resultados também foram encontrados na avaliação da resposta de pacientes vacinados com DCs transfectadas com mRNA tumoral (KYTE et al., 2007). Alguns mecanismos podem explicar porque os antigenos transfectados seriam apresentados por moléculas codificadas pelo MHCII. Se as DCs são transfectadas antes da maturação, que é nosso caso, algumas proteínas podem ser secretadas e capturadas pelas DCs imaturas, e então entram na via de apresentação por moléculas codificadas pelo MHCII. Ainda, peptídeos derivados de proteínas intracelulares podem ser apresentadas por HLA classe II através da sua captura em autofagossomos (DENGJEL et al., 2005; DORFEL et al., 2005). Assim, estes mecanismos podem explicar nossos primeiros resultados funcionais, que mostraram maior estimulação de linfócitos $\mathrm{T} \mathrm{CD4}^{+}$por DCs transfectadas com mRNA da survivina.

No sobrenadante das co-culturas foi detectada alta produção de IFN-gama, mas não de IL-10, o que é consistente com a ativação linfocitária observada. De fato, a literatura mostra que há maior produção de IFN-gama nas co-culturas feitas com DCs transfectadas com mRNA tumoral (NI et al., 2008). Contudo, em nossos resultados não houve diferença na produção de IFN-gama entre os linfócitos 
estimulados com DCs transfectadas e DCs controles. Isto sugere que a produção desta citocina foi devido ao efeito alogenêico das DCs e não à presença do mRNA.

Apesar dos linfócitos estimulados pelas DCs transfectadas com mRNA produzirem IFN-gama, no sobrenadante da cultura de DCs, controles e transfectadas, foi encontrado maior concentração de IL-10 do que de IL-12p70, ambas citocinas tendendo ao aumento nas DCs transfectadas. Neste caso, não temos resultados muito consistentes já que o número de amostras analisadas foi pequeno. Entretanto, é possível que estas DCs estivessem funcionalmente num estado mais imaturo, produzindo citocinas que levam a um padrão regulatório, por exemplo, TGF- $\beta$, o que poderia induzir células Treg. Não se pode excluir também a produção de outras citocinas inatas diferencialmente. Muito embora, Ni et al. (2008) mostraram que DCs transfectadas com mRNA amplificado obtido de células de linfoma estimulavam proliferação linfocitária sem induzir células Treg.

Com relação às moléculas de superfície características de DCs, de maneira geral, a frequência de células positivas para tais moléculas não mudou após a transfecção. Ainda que, quando observadas as populações duplo-positivas para os marcadores CD80 e CD86, CD40 e CD83, notam-se, nas DCs transfectadas, um aumento da expressão das moléculas co-estimuladoras (CD80 e CD86) e um aumento na freqüência de células positivas para as moléculas indicativas de ativação (CD83 e CD40). Estes dados são coerentes com os resultados de Gao et al. (2007), onde as DCs transfectadas apresentaram aumento na expressão das moléculas CD80, CD86, CD83 e HLA-DR. Entretanto, alguns trabalhos mostram que DCs imaturas transfectadas com antigenos tumorais não apresentam modificação no seu processo de maturação e nem na expressão dos marcadores característicos de DCs (BONEHILL et al., 2004), fenômeno este, igualmente observado em DCs transfectadas após a maturação (KANG et al., 2006). Ainda, este fenômeno foi encontrado também em nossos resultados, indicando que há controversas a respeito da alteração na expressão dos marcadores de superfície das DCs.

O aumento das moléculas de superfície das DCs, observado neste estudo, foi particularmente provocado pelo agente de transfecção, e não pela entrada do RNA nas células. A escolha do agente de transfecção deve ser cautelosa tanto pela sua toxicidade quanto pela ativação que provocam nas células. Neste ponto, nossos dados concordaram com os da literatura que mostram que os lipossomos ativam as 
DCs (ZHENG et al., 2010). Mas de qualquer maneira, estas permaneceram com fenótipo de DCs e capazes de estimularem os linfócitos in vitro.

Por fim, com este trabalho pode-se ressaltar que é possível amplificar in vitro o mRNA extraído de células tumorais e que a transfecção de DCs com mRNA pode afetar a resposta imune. Nossos dados sugerem que as DCs transfectadas são reconhecidas e estimulam linfócitos, suportando o uso desta estratégia para produção de vacinas anti-tumorais e além disso, mostrando a survivina como um potente antígeno capaz de induzir resposta linfocitária. 
6 CONCLUSÕES 
Os resultados obtidos indicam que:

- O RNA extraído de células tumorais de pacientes com LLC pode ser amplificado in vitro, sem perda da expressão do antigenos survivina e RPSA.

- Encontrou-se a lipofecção como forma mais eficiente para transfecção de DCs, e dentre as várias concentrações de RNA/lipossomo testadas a que pareceu melhor foi de $1 \mu \mathrm{g}$ de RNA com $3 \mu \mathrm{L}$ de lipofectamina 2000.

- A janela de tempo de expressão do mRNA da survivina transfectado nas DCs foi entre 12 e 24 horas.

- As DCs transfectadas com mRNA da survivina não tiveram suas moléculas de superfície alteradas (HLA-DR, CD14, CD80, CD86, CD40 e CD83) em freqüência, mas apresentaram aumento na expressão de CD80 e CD86.

- O tratamento com agente de transfecção e independentemente da presença do RNA ativou as DCs.

- As células transfectadas com mRNA da survivina foram capazes de estimular resposta linfoproliferativa com maior produção de IFN-gama. 
REFERÊNCIAS 


\section{REFERÊNCIAS ${ }^{1}$}

ADEMA, G. J.; HARTGERS, F.; VERSTRATEN, R.; DE VRIES, E.; MARLAND, G.; MENON, S.; FOSTER, J.; XU, Y.; NOOYEN, P.; MCCLANAHAN, T.; BACON, K. B.; FIGDOR, C. G. A dendritic-cell-derived C-C chemokine that preferentially attracts naive T cells. Nature, v. 387, n. 6634, p. 713-717, 1997.

ALMAND, B.; RESSER, J. R.; LINDMAN, B.; NADAF, S.; CLARK, J. I.; KWON, E. D.; CARBONE, D. P.; GABRILOVICH, D. I. Clinical significance of defective dendritic cell differentiation in cancer. Clin. Cancer Res., v. 6, n. 5, p. 1755-1766, 2000.

AZEVEDO-SANTOS, A. P. S. Efeito do microambiente tumoral sobre as características funcionais e fenotípicas de células dendríticas geradas in vitro a partir de monócitos do sangue periférico de voluntarias saudáveis e de pacientes com câncer de mama. 2010. 115 f. Tese (Doutorado em Imunologia) Instituto de Ciências Biomédicas, Universidade de São Paulo, São Paulo, 2010.

BALEEIRO, R. B.; ANSELMO, L. B.; SOARES, F. A.; PINTO, C. A.; RAMOS, O.; GROSS, J. L.; HADDAD, F.; YOUNES, R. N.; TOMIYOSHI, M. Y.; BERGAMISANTOS, P. C.; BARBUTO, J. A. High frequency of immature dendritic cells and altered in situ production of interleukin-4 and tumor necrosis factor-alpha in lung cancer. Cancer Immunol. Immunother., v. 57, n. 9, p. 1335-1345, 2008.

BALEEIRO, R.; DAHNE, L.; BAUDE, B.; LADEMANN, J.; WIESMULLER, K.; WALDEN, P. Induction of specific CD8+ T cell proliferation by human DC loaded with peptide coupled to TLR agonist. In: INTERNATIONAL SYMPOSIUM ON DENDRITIC CELLS IN FUNDAMENTAL AND CLINICAL IMMUNOLOGY - DC2010: FORUM ON VACCINE SCIENCe, 11., 2010, Lugano, Suiça. Abstracts... Lugano, Suiça: Institute for Research in Biomedicine and Swiss Vaccine Research Institute, 2010. res. P03081.

BANCHEREAU, J.; BRIERE, F.; CAUX, C.; DAVOUST, J.; LEBECQUE, S.; LIU, Y. J.; PULENDRAN, B.; PALUCKA, K. Immunobiology of dendritic cells. Annu. Rev. Immunol., v. 18, n., p. 767-811, 2000.

BANCHEREAU, J.; PALUCKA, A. K. Dendritic cells as therapeutic vaccines against cancer. Nat. Rev. Immunol., v. 5, n. 4, p. 296-306, 2005.

BANCHEREAU, J.; STEINMAN, R. M. Dendritic cells and the control of immunity. Nature, v. 392, n. 6673, p. 245-252, 1998.

\footnotetext{
${ }^{1}$ De acordo com: ASSOCIAÇÃO BRASILEIRA DE NORMAS TÉCNICAS. NBR 6023: Informação e documentação: referências: elaboração. Rio de Janeiro, 2002.
} 
BARBUTO, J. A.; ENSINA, L. F.; NEVES, A. R.; BERGAMI-SANTOS, P.; LEITE, K. R.; MARQUES, R.; COSTA, F.; MARTINS, S. C.; CAMARA-LOPES, L. H.; BUZAID, A. C. Dendritic cell-tumor cell hybrid vaccination for metastatic cancer. Cancer Immunol. Immunother., v. 53, n. 12, p. 1111-1118, 2004.

BARSOUM, A. L.; LIU, B.; ROHRER, J. W.; COGGIN, J. H., JR.; TUCKER, J. A.; PANNELL, L. K.; SCHWARZENBERGER, P. O. Production, safety and antitumor efficacy of recombinant Oncofetal Antigen/immature laminin receptor protein. Biomaterials, v. 30, n. 17, p. 3091-3099, 2009.

BELLONE, G.; CARBONE, A.; SMIRNE, C.; SCIRELLI, T.; BUFFOLINO, A.; NOVARINO, A.; STACCHINI, A.; BERTETTO, O.; PALESTRO, G.; SORIO, C.; SCARPA, A.; EMANUELLI, G.; RODECK, U. Cooperative induction of a tolerogenic dendritic cell phenotype by cytokines secreted by pancreatic carcinoma cells. J. Immunol., v. 177, n. 5, p. 3448-3460, 2006.

BERGANT, M.; MEDEN, L.; REPNIK, U.; SOJAR, V.; STANISAVLJEVIC, D.; JERAS, M. Preparation of native and amplified tumour RNA for dendritic cell transfection and generation of in vitro anti-tumour CTL responses. Immunobiology, v. 211, n. 3, p. 179-189, 2006.

BEVAN, M. J. Cross-priming. Nat. Immunol., v. 7, n. 4, p. 363-365, 2006.

BIRAGYN, A.; SCHIAVO, R.; OLKHANUD, P.; SUMITOMO, K.; KING, A.; MCCAIN, M.; INDIG, F. E.; ALMANZAR, G.; BAATAR, D. Tumor-associated embryonic antigen-expressing vaccines that target CCR6 elicit potent CD8+ $T$ cell-mediated protective and therapeutic antitumor immunity. J. Immunol., v. 179, n. 2, p. 13811388, 2007.

BOCZKOWSKI, D.; NAIR, S. RNA as performance-enhancers for dendritic cells. Expert Opin. Biol. Ther., v. 10, n. 4, p. 563-574, 2010.

BOCZKOWSKI, D.; NAIR, S. K.; NAM, J. H.; LYERLY, H. K.; GILBOA, E. Induction of tumor immunity and cytotoxic $T$ lymphocyte responses using dendritic cells transfected with messenger RNA amplified from tumor cells. Cancer Res., v. 60, n. 4, p. 1028-1034, 2000.

BONEHILL, A.; HEIRMAN, C.; TUYAERTS, S.; MICHIELS, A.; BRECKPOT, K.; BRASSEUR, F.; ZHANG, Y.; VAN DER BRUGGEN, P.; THIELEMANS, $K$. Messenger RNA-electroporated dendritic cells presenting MAGE-A3 simultaneously 
in HLA class I and class II molecules. J. Immunol., v. 172, n. 11, p. 6649-6657, 2004.

BONEHILL, A.; TUYAERTS, S.; VAN NUFFEL, A. M.; HEIRMAN, C.; BOS, T. J.; FOSTIER, K.; NEYNS, B.; THIELEMANS, K. Enhancing the T-cell stimulatory capacity of human dendritic cells by co-electroporation with CD40L, CD70 and constitutively active TLR4 encoding mRNA. Mol. Ther., v. 16, n. 6, p. 1170-1180, 2008.

BONEHILL, A.; VAN NUFFEL, A. M.; CORTHALS, J.; TUYAERTS, S.; HEIRMAN, C.; FRANCOIS, V.; COLAU, D.; VAN DER BRUGGEN, P.; NEYNS, B.; THIELEMANS, K. Single-step antigen loading and activation of dendritic cells by mRNA electroporation for the purpose of therapeutic vaccination in melanoma patients. Clin. Cancer Res., v. 15, n. 10, p. 3366-3375, 2009.

BONTKES, H. J.; KRAMER, D.; RUIZENDAAL, J. J.; MEIJER, C. J.; HOOIJBERG, E. Tumor associated antigen and interleukin-12 mRNA transfected dendritic cells enhance effector function of natural killer cells and antigen specific T-cells. Clin. Immunol., v. 127, n. 3, p. 375-384, 2008.

BROSSART, P.; WIRTHS, S.; STUHLER, G.; REICHARDT, V. L.; KANZ, L.; BRUGGER, W. Induction of cytotoxic T-lymphocyte responses in vivo after vaccinations with peptide-pulsed dendritic cells. Blood, v. 96, n. 9, p. 3102-3108, 2000.

BYRD, J. C.; GRIBBEN, J. G.; PETERSON, B. L.; GREVER, M. R.; LOZANSKI, G.; LUCAS, D. M.; LAMPSON, B.; LARSON, R. A.; CALIGIURI, M. A.; HEEREMA, N. A. Select high-risk genetic features predict earlier progression following chemoimmunotherapy with fludarabine and rituximab in chronic lymphocytic leukemia: justification for risk-adapted therapy. J. Clin. Oncol., v. 24, n. 3, p. 437443, 2006.

CAUX, C.; DEZUTTER-DAMBUYANT, C.; SCHMITT, D.; BANCHEREAU, J. GMCSF and TNF-alpha cooperate in the generation of dendritic Langerhans cells. Nature, v. 360, n. 6401, p. 258-261, 1992.

CAUX, C.; MASSACRIER, C.; VANBERVLIET, B.; DUBOIS, B.; VAN KOOTEN, C.; DURAND, I.; BANCHEREAU, J. Activation of human dendritic cells through CD40 cross-linking. J. Exp. Med., v. 180, n. 4, p. 1263-1272, 1994.

CHAPUT, N.; SCHARTZ, N. E.; ANDRE, F.; TAIEB, J.; NOVAULT, S.; BONNAVENTURE, P.; AUBERT, N.; BERNARD, J.; LEMONNIER, F.; MERAD, M.; ADEMA, G.; ADAMS, M.; FERRANTINI, M.; CARPENTIER, A. F.; ESCUDIER, B.; 
TURSZ, T.; ANGEVIN, E.; ZITVOGEL, L. Exosomes as potent cell-free peptidebased vaccine. II. Exosomes in CpG adjuvants efficiently prime naive Tc1 lymphocytes leading to tumor rejection. J. Immunol., v. 172, n. 4, p. 2137-2146, 2004.

DALL'OGLIO, M.; SROUGI, M.; BARBUTO, J. A. Complete response of metastatic renal cancer with dendritic cell vaccine. Int. Braz J. Urol., v. 29, n. 6, p. 517-519, 2003.

DE MARIA, S.; PANNONE, G.; BUFO, P.; SANTORO, A.; SERPICO, R.; METAFORA, S.; RUBINI, C.; PASQUALI, D.; PAPAGERAKIS, S. M.; STAIBANO, S.; DE ROSA, G.; FARINA, E.; EMANUELLI, M.; SANTARELLI, A.; MARIGGIO, M. A.; LO RUSSO, L.; LO MUZIO, L. Survivin gene-expression and splicing isoforms in oral squamous cell carcinoma. J. Cancer Res. Clin. Oncol., v. 135, n. 1, p. 107-116, 2009.

DEARDEN, C. Disease-specific complications of chronic lymphocytic leukemia. Hematology Am. Soc. Hematol. Educ. Program, v., n., p. 450-456, 2008.

DELLA BELLA, S.; GENNARO, M.; VACCARI, M.; FERRARIS, C.; NICOLA, S.; RIVA, A.; CLERICI, M.; GRECO, M.; VILLA, M. L. Altered maturation of peripheral blood dendritic cells in patients with breast cancer. Br. J. Cancer, v. 89, n. 8, p. 1463-1472, 2003.

DENGJEL, J.; SCHOOR, O.; FISCHER, R.; REICH, M.; KRAUS, M.; MULLER, M.; KREYMBORG, K.; ALTENBEREND, F.; BRANDENBURG, J.; KALBACHER, H.; BROCK, R.; DRIESSEN, C.; RAMMENSEE, H. G.; STEVANOVIC, S. Autophagy promotes $\mathrm{MHC}$ class II presentation of peptides from intracellular source proteins. Proc. Natl. Acad. Sci. U S A, v. 102, n. 22, p. 7922-7927, 2005.

DORFEL, D.; APPEL, S.; GRUNEBACH, F.; WECK, M. M.; MULLER, M. R.; HEINE, A.; BROSSART, P. Processing and presentation of HLA class I and II epitopes by dendritic cells after transfection with in vitro-transcribed MUC1 RNA. Blood, v. 105, n. 8, p. 3199-3205, 2005.

DREGER, P.; STILGENBAUER, S.; BENNER, A.; RITGEN, M.; KROBER, A.; KNEBA, M.; SCHMITZ, N.; DOHNER, H. The prognostic impact of autologous stem cell transplantation in patients with chronic lymphocytic leukemia: a risk-matched analysis based on the VH gene mutational status. Blood, v. 103, n. 7, p. 2850-2858, 2004. 
FADERL, S. J.; KEATING, M. J. Treatment of chronic lymphocytic leukemia. Curr. Hematol. Rep., v. 4, n. 1, p. 31-38, 2005.

GABRILOVICH, D. Mechanisms and functional significance of tumour-induced dendritic-cell defects. Nat. Rev. Immunol., v. 4, n. 12, p. 941-952, 2004.

GAO, L.; FAN, H. H.; LU, H. Z.; NIE, X. X.; LIU, Y.; YANG, Y. M.; QIAN, K. C.; GAO, F. Impact of transfection with total RNA of K562 cells upon antigen presenting, maturation, and function of human dendritic cells from peripheral blood mononuclear cells. Transfusion, v. 47, n. 2, p. 256-265, 2007.

GIANNOPOULOS, K.; LI, L.; BOJARSKA-JUNAK, A.; ROLINSKI, J.; DMOSZYNSKA, A.; HUS, I.; GREINER, J.; RENNER, C.; DOHNER, H.; SCHMITT, M. Expression of $\mathrm{RHAMM} / \mathrm{CD} 168$ and other tumor-associated antigens in patients with B-cell chronic lymphocytic leukemia. Int. J. Oncol., v. 29, n. 1, p. 95-103, 2006.

GILBOA, E. The promise of cancer vaccines. Nat. Rev. Cancer, v. 4, n. 5, p. 401411, 2004.

GILBOA, E. DC-based cancer vaccines. J. Clin. Invest., v. 117, n. 5, p. 1195-1203, 2007.

GILBOA, E.; VIEWEG, J. Cancer immunotherapy with mRNA-transfected dendritic cells. Immunol. Rev., v. 199, n., p. 251-263, 2004.

GINALDI, L.; DE MARTINIS, M.; MATUTES, E.; FARAHAT, N.; MORILLA, R.; CATOVSKY, D. Levels of expression of CD19 and CD20 in chronic B cell leukaemias. J. Clin. Pathol., v. 51, n. 5, p. 364-369, 1998.

GOLDIN, L. R.; SLAGER, S. L. Familial CLL: genes and environment. Hematology Am. Soc. Hematol. Educ. Program, p. 339-345, 2007.

GOTTFRIED, E.; KREUTZ, M.; MACKENSEN, A. Tumor-induced modulation of dendritic cell function. Cytokine Growth Factor Rev., v. 19, n. 1, p. 65-77, 2008.

GRIBBEN, J. G.; ZAHRIEH, D.; STEPHANS, K.; BARTLETT-PANDITE, L.; ALYEA, E. P.; FISHER, D. C.; FREEDMAN, A. S.; MAUCH, P.; SCHLOSSMAN, R.; SEQUIST, L. V.; SOIFFER, R. J.; MARSHALL, B.; NEUBERG, D.; RITZ, J.; NADLER, L. M. Autologous and allogeneic stem cell transplantations for poor-risk chronic lymphocytic leukemia. Blood, v. 106, n. 13, p. 4389-4396, 2005. 
GUERMONPREZ, P.; VALLADEAU, J.; ZITVOGEL, L.; THERY, C.; AMIGORENA, S. Antigen presentation and T cell stimulation by dendritic cells. Annu. Rev. Immunol., v. 20 , p. $621-667,2002$.

HALLEK, M.; CHESON, B. D.; CATOVSKY, D.; CALIGARIS-CAPPIO, F.; DIGHIERO, G.; DOHNER, H.; HILLMEN, P.; KEATING, M. J.; MONTSERRAT, E.; RAI, K. R.; KIPPS, T. J. Guidelines for the diagnosis and treatment of chronic lymphocytic leukemia: a report from the International Workshop on Chronic Lymphocytic Leukemia updating the National Cancer Institute-Working Group 1996 guidelines. Blood, v. 111, n. 12, p. 5446-5456, 2008.

HAMBLIN, A. D.; HAMBLIN, T. J. The immunodeficiency of chronic lymphocytic leukaemia. Br. Med. Bull, v. 87, p. 49-62, 2008.

HASEBE, H.; NAGAYAMA, H.; SATO, K.; ENOMOTO, M.; TAKEDA, Y.; TAKAHASHI, T. A.; HASUMI, K.; ERIGUCHI, M. Dysfunctional regulation of the development of monocyte-derived dendritic cells in cancer patients. Biomed. Pharmacother, v. 54, n. 6, p. 291-298, 2000.

HEIL, F.; HEMMI, H.; HOCHREIN, H.; AMPENBERGER, F.; KIRSCHNING, C.; AKIRA, S.; LIPFORD, G.; WAGNER, H.; BAUER, S. Species-specific recognition of single-stranded RNA via toll-like receptor 7 and 8 . Science, v. 303, n. 5663, p. 15261529, 2004.

HEISER, A.; MAURICE, M. A.; YANCEY, D. R.; WU, N. Z.; DAHM, P.; PRUITT, S. K.; BOCZKOWSKI, D.; NAIR, S. K.; BALLO, M. S.; GILBOA, E.; VIEWEG, J. Induction of polyclonal prostate cancer-specific CTL using dendritic cells transfected with amplified tumor RNA. J. Immunol., v. 166, n. 5, p. 2953-2960, 2001.

HERBER, D. L.; CAO, W.; NEFEDOVA, Y.; NOVITSKIY, S. V.; NAGARAJ, S.; TYURIN, V. A.; CORZO, A.; CHO, H. I.; CELIS, E.; LENNOX, B.; KNIGHT, S. C.; PADHYA, T.; MCCAFFREY, T. V.; MCCAFFREY, J. C.; ANTONIA, S.; FISHMAN, M.; FERRIS, R. L.; KAGAN, V. E.; GABRILOVICH, D. I. Lipid accumulation and dendritic cell dysfunction in cancer. Nat. Med., v. 16, n. 8, p. 880-886, 2010.

HOFLAND, H. E.; SHEPHARD, L.; SULLIVAN, S. M. Formation of stable cationic lipid/DNA complexes for gene transfer. Proc. Natl. Acad. Sci. U S A, v. 93, n. 14, p. 7305-7309, 1996.

HORNUNG, V.; LATZ, E. Intracellular DNA recognition. Nat. Rev. Immunol., v. 10, n. 2, p. 123-130, 2010. 
HUS, I.; SCHMITT, M.; TABARKIEWICZ, J.; RADEJ, S.; WOJAS, K.; BOJARSKAJUNAK, A.; SCHMITT, A.; GIANNOPOULOS, K.; DMOSZYNSKA, A.; ROLINSKI, J. Vaccination of B-CLL patients with autologous dendritic cells can change the frequency of leukemia antigen-specific CD8+ T cells as well as CD4+CD25+FoxP3+ regulatory $\mathrm{T}$ cells toward an antileukemia response. Leukemia, v. 22, n. 5, p. 10071017, 2008.

JARNJAK-JANKOVIC, S.; PETTERSEN, R. D.; SAEBOE-LARSSEN, S.; WESENBERG, F.; GAUDERNACK, G. Evaluation of dendritic cells loaded with apoptotic cancer cells or expressing tumour mRNA as potential cancer vaccines against leukemia. BMC Cancer, v. 5, p. 20, $2005 a$.

JARNJAK-JANKOVIC, S.; PETTERSEN, R. D.; SAEBOE-LARSSEN, S.; WESENBERG, F.; OLAFSEN, M. R.; GAUDERNACK, G. Preclinical evaluation of autologous dendritic cells transfected with mRNA or loaded with apoptotic cells for immunotherapy of high-risk neuroblastoma. Cancer Gene Ther., v. 12, n. 8, p. 699707, 2005b.

KANG, T. H.; LEE, J. H.; BAE, H. C.; NOH, K. H.; KIM, J. H.; SONG, C. K.; SHIN, B. C.; HUNG, C. F.; WU, T. C.; PARK, J. S.; KIM, T. W. Enhancement of dendritic cellbased vaccine potency by targeting antigen to endosomal/lysosomal compartments. Immunol. Lett., v. 106, n. 2, p. 126-134, 2006.

KHAN, S.; BIJKER, M. S.; WETERINGS, J. J.; TANKE, H. J.; ADEMA, G. J.; VAN HALL, T.; DRIJFHOUT, J. W.; MELIEF, C. J.; OVERKLEEFT, H. S.; VAN DER MAREL, G. A.; FILIPPOV, D. V.; VAN DER BURG, S. H.; OSSENDORP, F. Distinct uptake mechanisms but similar intracellular processing of two different toll-like receptor ligand-peptide conjugates in dendritic cells. J. Biol. Chem., v. 282, n. 29, p. 21145-21159, 2007.

KHAN, S.; JUTZY, J. M.; ASPE, J. R.; MCGREGOR, D. W.; NEIDIGH, J. W.; WALL, N. R. Survivin is released from cancer cells via exosomes. Apoptosis, published online, 2010.

KOWALSKA, J.; LEWDOROWICZ, M.; ZUBEREK, J.; GRUDZIEN-NOGALSKA, E.; BOJARSKA, E.; STEPINSKI, J.; RHOADS, R. E.; DARZYNKIEWICZ, E.; DAVIS, R. E.; JEMIELITY, J. Synthesis and characterization of mRNA cap analogs containing phosphorothioate substitutions that bind tightly to elF4E and are resistant to the decapping pyrophosphatase DcpS. RNA, v. 14, n. 6, p. 1119-1131, 2008.

KUHN, A. N.; DIKEN, M.; KREITER, S.; SELMI, A.; KOWALSKA, J.; JEMIELITY, J.; DARZYNKIEWICZ, E.; HUBER, C.; TURECI, O.; SAHIN, U. Phosphorothioate cap analogs increase stability and translational efficiency of RNA vaccines in immature 
dendritic cells and induce superior immune responses in vivo. Gene Ther., v. 17, n. 8, p. 961-971, 2010.

KYTE, J. A.; KVALHEIM, G.; LISLERUD, K.; THOR STRATEN, P.; DUELAND, S.; AAMDAL, S.; GAUDERNACK, G. T cell responses in melanoma patients after vaccination with tumor-mRNA transfected dendritic cells. Cancer Immunol. Immunother., v. 56, n. 5, p. 659-675, 2007.

LANDI, A.; BABIUK, L. A.; VAN DRUNEN LITTEL-VAN DEN HURK, S. High transfection efficiency, gene expression, and viability of monocyte-derived human dendritic cells after nonviral gene transfer. J. Leukoc. Biol., v. 82, n. 4, p. 849-860, 2007.

LAPPALAINEN, K.; MIETTINEN, R.; KELLOKOSKI, J.; JAASKELAINEN, I.; SYRJANEN, S. Intracellular distribution of oligonucleotides delivered by cationic liposomes: light and electron microscopic study. J. Histochem. Cytochem., v. 45, n. 2, p. 265-274, 1997.

LASIC, D. D.; PAPAHADJOPOULOS, D. Liposomes revisited. Science, v. 267, n. 5202, p. 1275-1276, 1995.

LEWIN, B. Genes VII. Porto Alegre: Oxford University Press and Cell Press, 2000.

LI, F.; AMBROSINI, G.; CHU, E. Y.; PLESCIA, J.; TOGNIN, S.; MARCHISIO, P. C.; ALTIERI, D. C. Control of apoptosis and mitotic spindle checkpoint by survivin. Nature, v. 396, n. 6711, p. 580-584, 1998.

LIVAK, K. J.; SCHMITTGEN, T. D. Analysis of relative gene expression data using real-time quantitative PCR and the 2(-Delta Delta C(T)) Method. Methods, v. 25, n. 4, p. 402-408, 2001.

LOPES, R.; CASTRO, I.; PONTES, P.; CANDEIAS, J.; LEMOINE, N. R.; SAMBADE, C. Expression profile of survivin in acute leukaemias: the importance of differential splicing. Leukemia, v. 19, n. 7, p. 1284-1286, 2005.

LYONS, A. B. Analysing cell division in vivo and in vitro using flow cytometric measurement of CFSE dye dilution. J. Immunol. Methods, v. 243, n. 1-2, p. 147154, 2000. 
MANDRUZZATO, S.; BRASSEUR, F.; ANDRY, G.; BOON, T.; VAN DER BRUGGEN, P. A CASP-8 mutation recognized by cytolytic $T$ lymphocytes on a human head and neck carcinoma. J. Exp. Med., v. 186, n. 5, p. 785-793, 1997.

MAURO, F. R.; FOA, R.; GIANNARELLI, D.; CORDONE, I.; CRESCENZI, S.; PESCARMONA, E.; SALA, R.; CERRETTI, R.; MANDELLI, F. Clinical characteristics and outcome of young chronic lymphocytic leukemia patients: a single institution study of 204 cases. Blood, v. 94, n. 2, p. 448-454, 1999.

MAYORDOMO, J. I.; ZORINA, T.; STORKUS, W. J.; ZITVOGEL, L.; CELLUZZI, C.; FALO, L. D.; MELIEF, C. J.; ILDSTAD, S. T.; KAST, W. M.; DELEO, A. B.; ET AL. Bone marrow-derived dendritic cells pulsed with synthetic tumour peptides elicit protective and therapeutic antitumour immunity. Nat. Med., v. 1, n. 12, p. 1297-1302, 1995.

MELHEM, N. M.; GLEASON, S. M.; LIU, X. D.; BARRATT-BOYES, S. M. High-level antigen expression and sustained antigen presentation in dendritic cells nucleofected with wild-type viral mRNA but not DNA. Clin. Vaccine Immunol., v. 15, n. 9, p. 13371344, 2008.

MELLMAN, I.; STEINMAN, R. M. Dendritic cells: specialized and regulated antigen processing machines. Cell, v. 106, n. 3, p. 255-258, 2001.

MENEZES, G. F. Desenvolvimento de método de avaliação da indução de imunidade específica contra células neoplásicas pela transfecção de monócitos com RNA tumoral. 2008. 104 f. Dissertação (Mestrado em Imunologia) - Instituto de Ciências Biomédicas, Universidade de São Paulo, São Paulo, 2008.

MOHAMADZADEH, M.; LUFTIG, R. Dendritic cells: In the forefront of immunopathogenesis and vaccine development - A review. J. Immune Based Ther. Vaccines, v. 2, n. 1, p. 1, 2004.

MOREL, S.; LEVY, F.; BURLET-SCHILTZ, O.; BRASSEUR, F.; PROBST-KEPPER, M.; PEITREQUIN, A. L.; MONSARRAT, B.; VAN VELTHOVEN, R.; CEROTTINI, J. C.; BOON, T.; GAIRIN, J. E.; VAN DEN EYNDE, B. J. Processing of some antigens by the standard proteasome but not by the immunoproteasome results in poor presentation by dendritic cells. Immunity, v. 12, n. 1, p. 107-117, 2000.

MORENO, C.; MONTSERRAT, E. New prognostic markers in chronic lymphocytic leukemia. Blood Rev., v. 22, n. 4, p. 211-219, 2008. 
MU, L. J.; GAUDERNACK, G.; SAEBOE-LARSSEN, S.; HAMMERSTAD, H.; TIERENS, A.; KVALHEIM, G. A protocol for generation of clinical grade mRNAtransfected monocyte-derived dendritic cells for cancer vaccines. Scand. J. Immunol., v. 58, n. 5, p. 578-586, 2003.

MU, L. J.; KYTE, J. A.; KVALHEIM, G.; AAMDAL, S.; DUELAND, S.; HAUSER, M.; HAMMERSTAD, H.; WAEHRE, H.; RAABE, N.; GAUDERNACK, G. Immunotherapy with allotumour mRNA-transfected dendritic cells in androgen-resistant prostate cancer patients. Br. J. Cancer, v. 93, n. 7, p. 749-756, 2005.

MULLER, M. R.; TSAKOU, G.; GRUNEBACH, F.; SCHMIDT, S. M.; BROSSART, P. Induction of chronic lymphocytic leukemia (CLL)-specific CD4- and CD8-mediated Tcell responses using RNA-transfected dendritic cells. Blood, v. 103, n. 5, p. 17631769, 2004.

NAGARAJ, S.; PISAREV, V.; KINARSKY, L.; SHERMAN, S.; MURO-CACHO, C.; ALTIERI, D. C.; GABRILOVICH, D. I. Dendritic cell-based full-length survivin vaccine in treatment of experimental tumors. J. Immunother., v. 30, n. 2, p. 169-179, 2007.

NAIK, S. H. Demystifying the development of dendritic cell subtypes, a little. Immunol. Cell Biol., v. 86, n. 5, p. 439-452, 2008.

NEVES, A. R.; ENSINA, L. F.; ANSELMO, L. B.; LEITE, K. R.; BUZAID, A. C.; CAMARA-LOPES, L. H.; BARBUTO, J. A. Dendritic cells derived from metastatic cancer patients vaccinated with allogeneic dendritic cell-autologous tumor cell hybrids express more CD86 and induce higher levels of interferon-gamma in mixed lymphocyte reactions. Cancer Immunol. Immunother., v. 54, n. 1, p. 61-66, 2005.

NI, X.; RICHMOND, H. M.; LIAO, X. M.; DECKER, W. K.; SHIUE, L. H.; SHPALL, E. J.; DUVIC, M. Induction of T-cell responses against cutaneous T-cell lymphomas ex vivo by autologous dendritic cells transfected with amplified tumor mRNA. J. Invest. Dermatol., v. 128, n. 11, p. 2631-2639, 2008.

OLEJNICZAK, M.; GALKA, P.; KRZYZOSIAK, W. J. Sequence-non-specific effects of RNA interference triggers and microRNA regulators. Nucleic Acids Res., v. 38, n. 1, p. 1-16, 2010.

ORSINI, E.; GUARINI, A.; CHIARETTI, S.; MAURO, F. R.; FOA, R. The circulating dendritic cell compartment in patients with chronic lymphocytic leukemia is severely defective and unable to stimulate an effective T-cell response. Cancer Res., v. 63, n. 15, p. 4497-4506, 2003. 
ORSINI, E.; PASQUALE, A.; MAGGIO, R.; CALABRESE, E.; MAURO, F. R.; GIAMMARTINI, E.; GUARINI, A.; FOA, R. Phenotypic and functional characterization of monocyte-derived dendritic cells in chronic lymphocytic leukaemia patients: influence of neoplastic CD19 cells in vivo and in vitro. Br. J. Haematol., v. 125, n. 6, p. 720-728, 2004.

PALMA, M.; ADAMSON, L.; HANSSON, L.; KOKHAEI, P.; REZVANY, R.; MELLSTEDT, H.; OSTERBORG, A.; CHOUDHURY, A. Development of a dendritic cell-based vaccine for chronic lymphocytic leukemia. Cancer Immunol. Immunother., v. 57, n. 11, p. 1705-1710, 2008.

PIESCHE, M.; HILDEBRANDT, Y.; ZETTL, F.; CHAPUY, B.; SCHMITZ, M.; WULF, G.; TRUMPER, L.; SCHROERS, R. Identification of a promiscuous HLA DRrestricted T-cell epitope derived from the inhibitor of apoptosis protein survivin. Hum. Immunol., v. 68, n. 7, p. 572-576, 2007.

PONSAERTS, P.; VAN TENDELOO, V. F.; COOLS, N.; VAN DRIESSCHE, A.; LARDON, F.; NIJS, G.; LENJOU, M.; MERTENS, G.; VAN BROECKHOVEN, C.; VAN BOCKSTAELE, D. R.; BERNEMAN, Z. N. mRNA-electroporated mature dendritic cells retain transgene expression, phenotypical properties and stimulatory capacity after cryopreservation. Leukemia, v. 16, n. 7, p. 1324-1330, 2002.

RAMOS, R. N.; Chin, L. S.; Azevedo, A. P. S; Bergami-Santos, P. C.; Laginha, F.; Barbuto, J. A. M. Monocyte-derived immature dendritic cells from breast cancer patients induce high frequency of CD4+CD25+FOXP3+ regulatory I cells in vitro. In: INTERNATIONAL SYMPOSIUM ON DENDRITIC CELLS IN FUNDAMENTAL AND CLINICAL IMMUNOLOGY - DC2010: FORUM ON VACCINE SCIENCE, 11., 2010, Lugano, Suiça. Abstracts... Lugano, Suiça: Institute for Research in Biomedicine and Swiss Vaccine Research Institute, 2010. res. P05-087.

ROMAGNOLI, G. G.; Bergami-Santos, P. C.; Barbuto, J. A. M. A new approach for a cancer immunotherapy: The use of nanovesicles from mature dendritic cells to make immunogenic tumor cells. In: INTERNATIONAL SYMPOSIUM ON DENDRITIC CELLS IN FUNDAMENTAL AND CLINICAL IMMUNOLOGY - DC2010: FORUM ON VACCINE SCIENCE, 11., 2010, Lugano, Suiça. Abstracts... Lugano, Suiça: Institute for Research in Biomedicine and Swiss Vaccine Research Institute, 2010. res. P05051.

ROMANI, N.; REIDER, D.; HEUER, M.; EBNER, S.; KAMPGEN, E.; EIBL, B.; NIEDERWIESER, D.; SCHULER, G. Generation of mature dendritic cells from human blood. An improved method with special regard to clinical applicability. $J$ Immunol. Methods, v. 196, n. 2, p. 137-151, 1996. 
ROSENBERG, S. A.; YANG, J. C.; RESTIFO, N. P. Cancer immunotherapy: moving beyond current vaccines. Nat. Med., v. 10, n. 9, p. 909-915, 2004.

SALLUSTO, F.; LANZAVECCHIA, A. Efficient presentation of soluble antigen by cultured human dendritic cells is maintained by granulocyte/macrophage colonystimulating factor plus interleukin 4 and downregulated by tumor necrosis factor alpha. J. Exp. Med., v. 179, n. 4, p. 1109-1118, 1994.

SALLUSTO, F.; PALERMO, B.; LENIG, D.; MIETTINEN, M.; MATIKAINEN, S.; JULKUNEN, I.; FORSTER, R.; BURGSTAHLER, R.; LIPP, M.; LANZAVECCHIA, A. Distinct patterns and kinetics of chemokine production regulate dendritic cell function.

Eur. J. Immunol., v. 29, n. 5, p. 1617-1625, 1999.

SCHMIDT, S. M.; SCHAG, K.; MULLER, M. R.; WECK, M. M.; APPEL, S.; KANZ, L.; GRUNEBACH, F.; BROSSART, P. Survivin is a shared tumor-associated antigen expressed in a broad variety of malignancies and recognized by specific cytotoxic $T$ cells. Blood, v. 102, n. 2, p. 571-576, 2003.

SCHUURHUIS, D. H.; VAN MONTFOORT, N.; IOAN-FACSINAY, A.; JIAWAN, R.; CAMPS, M.; NOUTA, J.; MELIEF, C. J.; VERBEEK, J. S.; OSSENDORP, F. Immune complex-loaded dendritic cells are superior to soluble immune complexes as antitumor vaccine. J. Immunol., v. 176, n. 8, p. 4573-4580, 2006.

SCHUURHUIS, D. H.; VERDIJK, P.; SCHREIBELT, G.; AARNTZEN, E. H.; SCHARENBORG, N.; DE BOER, A.; VAN DE RAKT, M. W.; KERKHOFF, M.; GERRITSEN, M. J.; EIJCKELER, F.; BONENKAMP, J. J.; BLOKX, W.; VAN KRIEKEN, J. H.; BOERMAN, O. C.; OYEN, W. J.; PUNT, C. J.; FIGDOR, C. G.; ADEMA, G. J.; DE VRIES, I. J. In situ expression of tumor antigens by messenger RNA-electroporated dendritic cells in lymph nodes of melanoma patients. Cancer Res., v. 69, n. 7, p. 2927-2934, 2009.

SIEGEL, S.; WAGNER, A.; FRIEDRICHS, B.; WENDELER, A.; WENDEL, L.; KABELITZ, D.; STEINMANN, J.; BARSOUM, A.; COGGIN, J.; ROHRER, J.; DREGER, P.; SCHMITZ, N.; ZEIS, M. Identification of HLA-A*0201-presented T cell epitopes derived from the oncofetal antigen-immature laminin receptor protein in patients with hematological malignancies. J. Immunol., v. 176, n. 11, p. 6935-6944, 2006.

SIEGEL, S.; WAGNER, A.; KABELITZ, D.; MARGET, M.; COGGIN, J., JR.; BARSOUM, A.; ROHRER, J.; SCHMITZ, N.; ZEIS, M. Induction of cytotoxic T-cell responses against the oncofetal antigen-immature laminin receptor for the treatment of hematologic malignancies. Blood, v. 102, n. 13, p. 4416-4423, 2003. 
STEINMAN, R. M. The control of immunity and tolerance by dendritic cell. Pathol. Biol. (Paris), v. 51, n. 2, p. 59-60, 2003.

STEINMAN, R. M.; BANCHEREAU, J. Taking dendritic cells into medicine. Nature, v. 449, n. 7161, p. 419-426, 2007.

TREFZER, U.; HERBERTH, G.; WOHLAN, K.; MILLING, A.; THIEMANN, M.; SHARAV, T.; SPARBIER, K.; STERRY, W.; WALDEN, P. Tumour-dendritic hybrid cell vaccination for the treatment of patients with malignant melanoma: immunological effects and clinical results. Vaccine, v. 23, n. 17-18, p. 2367-2373, 2005.

TREFZER, U.; WEINGART, G.; CHEN, Y.; HERBERTH, G.; ADRIAN, K.; WINTER, H.; AUDRING, H.; GUO, Y.; STERRY, W.; WALDEN, P. Hybrid cell vaccination for cancer immune therapy: first clinical trial with metastatic melanoma. Int. J. Cancer, v. 85, n. 5, p. 618-626, 2000.

UENO, H.; TCHEREPANOVA, I.; REYGROBELLET, O.; LAUGHNER, E.; VENTURA, C.; PALUCKA, A. K.; BANCHEREAU, J. Dendritic cell subsets generated from CD34+ hematopoietic progenitors can be transfected with mRNA and induce antigen-specific cytotoxic T cell responses. J. Immunol. Methods, v. 285, n. 2, p. 171-180, 2004.

VAN TENDELOO, V. F.; PONSAERTS, P.; LARDON, F.; NIJS, G.; LENJOU, M.; VAN BROECKHOVEN, C.; VAN BOCKSTAELE, D. R.; BERNEMAN, Z. N. Highly efficient gene delivery by mRNA electroporation in human hematopoietic cells: superiority to lipofection and passive pulsing of mRNA and to electroporation of plasmid cDNA for tumor antigen loading of dendritic cells. Blood, v. 98, n. 1, p. 4956, 2001.

VIAUD, S.; TERME, M.; FLAMENT, C.; TAIEB, J.; ANDRE, F.; NOVAULT, S.; ESCUDIER, B.; ROBERT, C.; CAILLAT-ZUCMAN, S.; TURSZ, T.; ZITVOGEL, L.; CHAPUT, N. Dendritic cell-derived exosomes promote natural killer cell activation and proliferation: a role for NKG2D ligands and IL-15Ralpha. PLoS One, v. 4, n. 3, p. e4942, 2009.

VIAUD, S.; THERY, C.; PLOIX, S.; TURSZ, T.; LAPIERRE, V.; LANTZ, O.; ZITVOGEL, L.; CHAPUT, N. Dendritic cell-derived exosomes for cancer immunotherapy: what's next? Cancer Res., v. 70, n. 4, p. 1281-1285, 2010.

WANG, K.; ZHOU, Q.; GUO, A. L.; XU, C. R.; AN, S. J.; WU, Y. L. An autologous therapeutic dendritic cell vaccine transfected with total lung carcinoma RNA 
stimulates cytotoxic $\mathrm{T}$ lymphocyte responses against non-small cell lung cancer. Immunol. Invest., v. 38, n. 7, p. 665-680, 2009.

WANG, S.; HONG, S.; YANG, J.; QIAN, J.; ZHANG, X.; SHPALL, E.; KWAK, L. W.; YI, Q. Optimizing immunotherapy in multiple myeloma: Restoring the function of patients' monocyte-derived dendritic cells by inhibiting p38 or activating MEK/ERK MAPK and neutralizing interleukin-6 in progenitor cells. Blood, v. 108, n. 13, p. 40714077, 2006.

WEIDE, B.; CARRALOT, J. P.; REESE, A.; SCHEEL, B.; EIGENTLER, T. K.; HOERR, I.; RAMMENSEE, H. G.; GARBE, C.; PASCOLO, S. Results of the first phase I/II clinical vaccination trial with direct injection of mRNA. J. Immunother., $v$. 31, n. 2, p. 180-188, 2008.

WEIDE, B.; PASCOLO, S.; SCHEEL, B.; DERHOVANESSIAN, E.; PFLUGFELDER, A.; EIGENTLER, T. K.; PAWELEC, G.; HOERR, I.; RAMMENSEE, H. G.; GARBE, C. Direct injection of protamine-protected mRNA: results of a phase $1 / 2$ vaccination trial in metastatic melanoma patients. J. Immunother., v. 32, n. 5, p. 498-507, 2009.

WOLFEL, T.; HAUER, M.; SCHNEIDER, J.; SERRANO, M.; WOLFEL, C.; KLEHMANN-HIEB, E.; DE PLAEN, E.; HANKELN, T.; MEYER ZUM BUSCHENFELDE, K. H.; BEACH, D. A p16INK4a-insensitive CDK4 mutant targeted by cytolytic T lymphocytes in a human melanoma. Science, v. 269, n. 5228, p. 12811284, 1995.

ZEIS, M.; SIEGEL, S.; WAGNER, A.; SCHMITZ, M.; MARGET, M.; KUHLBURMEISTER, R.; ADAMZIK, I.; KABELITZ, D.; DREGER, P.; SCHMITZ, N.; HEISER, A. Generation of cytotoxic responses in mice and human individuals against hematological malignancies using survivin-RNA-transfected dendritic cells. J. Immunol., v. 170, n. 11, p. 5391-5397, 2003.

ZELLE-RIESER, C.; BARSOUM, A. L.; SALLUSTO, F.; RAMONER, R.; ROHRER, J. W.; HOLTL, L.; BARTSCH, G.; COGGIN, J. J.; THURNHER, M. Expression and immunogenicity of oncofetal antigen-immature laminin receptor in human renal cell carcinoma. J. Urol., v. 165, n. 5, p. 1705-1709, 2001.

ZENZ, T.; MERTENS, D.; KUPPERS, R.; DOHNER, H.; STILGENBAUER, S. From pathogenesis to treatment of chronic lymphocytic leukaemia. Nat. Rev. Cancer., v. 10 , n. 1, p. 37-50, 2010.

ZHENG, X.; SUZUKI, M.; ICHIM, T. E.; ZHANG, X.; SUN, H.; ZHU, F.; SHUNNAR, A.; GARCIA, B.; INMAN, R. D.; MIN, W. Treatment of autoimmune arthritis using 
RNA interference-modulated dendritic cells. J. Immunol., v. 184, n. 11, p. 64576464, 2010. 